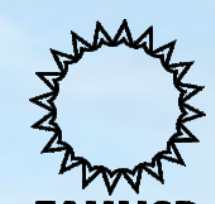

\title{
FAUUSP
}

UNIVERSIDADE DE SÃO PAULO

FACULDADE DE ARQUITETURA E URBANISMO

\section{Campus da Fiocruz no Ceará: aplicação das infraestruturas verdes no contexto do semiárido}

\section{GERSON AMARAL LIMA}




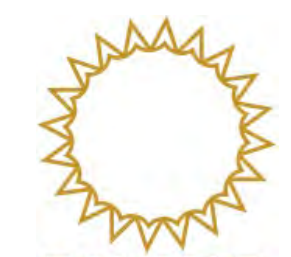

\section{FAUUSP}

UNIVERSIDADE DE SÃO PAULO

FACULDADE DE ARQUITETURA E URBANISMO

GERSON AMARAL LIMA

Campus da Fiocruz no Ceará:

aplicação das infraestruturas verdes

no contexto do semiárido 



\section{GERSON AMARAL LIMA}

\section{Campus da Fiocruz no Ceará: aplicação das infraestruturas verdes no contexto do semiárido}

Dissertação apresentada ao Programa de PósGraduação em Arquitetura e Urbanismo da Universidade de São Paulo para obtenção do título de Mestre em Arquitetura e Urbanismo

Área de Concentração: Paisagem e Ambiente

Orientador: Prof. Dr. Paulo Renato Mesquita Pellegrino

São Paulo

2016 
AUTORIZO A REPRODUÇÃO E DIVULGAÇÃO TOTAL OU PARCIAL DESTE TRABALHO, POR QUALQUER MEIO CONVENCIONAL OU ELETRÔNICO, PARA FINS DE ESTUDO E PESQUISA, DESDE QUE CITADA A FONTE.

E-Mail do Autor: gersonamaral.arq@gmail.com

Exemplar revisado e alterado em relação à versão original, sob responsabilidade do autor e anuência do orientador.

O original se encontra disponível na sede do programa.

São Paulo, 25 de julho de 2016.

Lima, Gerson Amaral
L732c Campus da Fiocrus no Ceará: aplicação das infraestruturas no contexto do semiárido / Gerson Amaral Lima. --São Paulo, 2016.

151 p. : il.

Dissertação (Mestrado - Área de Concentração: Paisagem e Ambiente) - FAUUSP.

Orientador: Paulo Renato Mesquita Pellegrino

1.Drenagem urbana 2.Arquitetura paisagística 3.Infraestrutr a urbana 4.Sustentabilidade I.Título

CDU 627.532 
Nome: LIMA, Gerson Amaral

Título: Campus da Fiocruz no Ceará: aplicação das infraestruturas verdes no contexto do semiárido

DissertaçãoapresentadaaoProgramadePósGraduação em Arquitetura e Urbanismo da Universidade de São Paulo para obtenção do título de Mestre em Arquitetura e Urbanismo

Aprovado em: 16/06/2016

Banca Examinadora

Prof. Dr. Paulo Renato Mesquita Pellegrino Instituição: FAU - USP Julgamento:

Assinatura:

Prof. Dr. José Rodolfo Scarati Martins

Instituição: PHA-Politécnica-USP

Julgamento:

Assinatura:

Prof.Dr. Newton Celio Becker de Moura

Instituição: UFC

Julgamento:

Assinatura: 

"Although many of the environmental challenges facing cities are more substantial than ever before, the understanding and the tools available to meet them are far more sophisticated. They need only be applied. Nature in the city must be cultivated and integrated with the varied pursuits and purposes of human beings; but first it must be recognized, and its power to shape human enterprises appreciated."

Anne Spirn 



\section{RESUMO}

O conceito de Infraestruturas Verdes, apesar de bastante abrangente em suas aplicações, vem sendo consolidado nos últimos anos no Brasil vinculado principalmente à utilização de soluções técnicas de baixo impacto e alto desempenho para manejo das águas pluviais, com o objetivo de reduzir as taxas de escoamento superficial e retenção da poluição difusa no meio urbano. Essas soluções, integradas tanto às edificações quanto aos espaços livres, possuem matriz orgânica e utilizam os recursos naturais locais para sua construção. As variações na composição de solo, no clima, na composição biótica, na situação urbanística, econômica e social influenciam de forma decisiva a configuração final e aplicação das soluções de infraestruturas verdes. Por esse motivo, a tecnologia exige que seja absorvida e reformulada em consonância aos condicionantes locais, formulando uma técnica própria para cada contexto em que se aplica. A dissertação aqui apresentada faz uma análise do desenvolvimento do projeto de infraestruturas verdes desenvolvido para o Campus da Fiocruz no Ceará, o qual consiste na primeira experiência de aplicação de tais conceitos no contexto do semiárido nordestino. 0 autor da pesquisa é também o autor do projeto em tela, de forma que a dissertação adquire certo caráter de memorial de projeto, explanando os objetivos desejados, os desafios enfrentados para alcance das metas de projeto e apresenta o projeto das soluções finais para cada um dos componentes do sistema de drenagem proposto. Ao final, fica evidente a dificuldade para a incorporação de conceitos inovadores de drenagem pluvial em um projeto com tantos profissionais envolvidos, mas, ao mesmo tempo, as infraestruturas verdes mostraram, em projeto, sua facilidade em trazer respostas mais simples, eficientes e de menor custo para a resolução de diferentes desafios que surgiram durante o processo de concepção.

Palavras-chave: Infraestrutura Verde / Urbanismo ecológico / Fiocruz Ceará 



\section{ABSTRACT}

The concept of Green infrastructure has been consolidated in the last years in Brazil despite its wide range of applications. It has been linked mainly to the use of low-impact, high efficiency technical solutions for the management of rainwater in order to reduce the levels of superficial outflow and retention of urban pollution. Local natural resources are used for the construction of these solutions, which have organic matrix. These solutions are integrated both to buildings and open spaces. The variations in soil and biotic composition, climate as well as urban, economic and social situations heavily impact on the final configuration and application of green infrastructure solutions. For those reasons, the technology must be absorbed and reformulated accordingly with the local conditions, adapting a unique technique for each context. This master thesis analyses the development of Ceará State Fiocruz Campus green infrastructure project, which marks the first time these concepts are used in the Brazilian Northeastern semiarid. The researcher here is also the author of the project, which characterizes this master thesis as a project memorial, explaining the desired objectives, the challenges faced when trying to meet the goals as well as presenting the final solutions for each component of the proposed rainwater drainage. At the end, it became clear the difficulties for the execution of rainwater management new concepts in a project that involves so many professionals. However, at the same time, the green infrastructures showed, in the project, their facility in bringing simpler, cheaper and more efficient answers to solving challenges that came up in the course of the concept process.

Keywords: Green infrastructure, Ecological Urbanism, Fiocruz Ceará 



\section{LISTA DE DESENHOS}

Desenho 01 O esquema concebido por Ebenezer Howard onde mostra a distribuição geral da Cidade-Jardim, com destaque ao uso de baixas densidades e valorização das áreas verdes dentro da cidade.

Desenho 02 Processos espaciais resultantes de processos naturais e atividades humanas.

Desenho 03 Exemplos de sistemas comerciais industrializados utilizados para implantação de telhados verdes com diferentes desempenhos técnicos.

Desenho 04 Produção gráfica da Oficina de Infraestruturas Verdes. Fotomontagem conceitual para o redesenho do canal do Tejo.

Desenho 05 Produção gráfica da Oficina de Infraestruturas Verdes. Fotomontagem conceitual dos eixos verdes e eixos azuis.

Desenho 06 Produção gráfica da Oficina de Infraestruturas Verdes. Fotomontagem conceitual das diversas soluções de circulação, drenagem e paisagismo na incorporação de soluções infraestruturais de baixo impacto e maior resiliência.

Desenho 07 Terreno da Fiocruz no contexto do Pólo Industrial e Tecnológico da Saúde.

Desenho 08 Visão geral do campus da Fiocruz Ceará em sua primeira fase de implantação.

Desenho 09 Imagem digital do acesso principal ao campus da Fiocruz Ceará.

Desenho 10 Seção típica das unidades de retenção.

Desenho 11 Esquema de captação e retenção das águas pluviais das vias do Campus da Fiocruz.

Desenho 12 Diferenças entre o primeiro detalhamento do extravasor (a esquerda) e a versão final, alinhada com os princípios da IEV.

Desenho 13 Perspectiva do projeto para lagoa pluvial em substituição a cisterna de detenção e filtro vortex.

Desenho 14 Perspectiva do projeto da lagoa pluvial. A ideia de criação do corpo d'agua incentivou o aproveitamento de sua qualidade espacial para a criação de áreas livres de lazer contemplativo.

Desenho 15 Perspectiva do projeto da lagoa pluvial. Concebida também para servir de habitat para peixes e aves aquáticas, incorporando espécies vegetais locais para incremento da biodiversidade. 



\section{LISTA DE FOTOS}

Foto 01 Condomínio residencial junto a foz do rio Pacoti Município de Eusébio, Ceará.

Foto 02 Alcazar de Segóvia (séc XII) implantado estrategicamente sobre um penhasco na confluência de dois rios.

Foto 03 Exemplo de transformação drástica de terras alagáveis para viabilizar a sua incorporação pelo mercado imobiliário. Pembroke Falls, Florida-EUA.

Foto 04 Exemplo de transformação drástica de terras alagáveis para viabilizar a sua incorporação pelo mercado imobiliário. Pembroke Falls, Florida-EUA.

Foto 05 Exemplo de transformação drástica de terras alagáveis para viabilizar a sua incorporação pelo mercado imobiliário. Pembroke Falls, Florida-EUA.

Foto $06 \quad$ No século XIX as áreas verdes dentro do espaço urbano ganharam importância, especialmente em Londres, pelos benefícios a saúde que um ambiente bucólico promove. Imagem: Hyde Park, Londres.

Foto 07 The Fens, trecho do Emerald Necklace, em sua configuração atual.

Foto 08 Midtown Greenway em Minneapolis.

Foto 09

Parque Ecológico do Cocó (Fortaleza-CE)

Foto 10 Aplicação do Código Florestal visa a conservação da mata ciliar dos rios brasileiros.

Foto 11 Exemplos típicos do carreamento de lixo doméstico e sedimentos durante os eventos de precipitação. Quando não prejudicam a vazão do sistema de drenagem, comprometem a qualidade das águas de córregos, rios e praias. Local: Fortaleza-CE.

Foto 12

Exemplos típicos do carreamento de lixo doméstico e sedimentos durante os eventos de precipitação. Quando não prejudicam a vazão do sistema de drenagem, comprometem a qualidade das águas de córregos, rios e praias. Local: Fortaleza-CE.

Foto 13

Exemplos típicos do carreamento de lixo doméstico e sedimentos durante os eventos de precipitação. Quando não prejudicam a vazão do sistema de drenagem, comprometem a qualidade das águas de córregos, rios e praias. Local: Fortaleza-CE.

Foto 14 Mancha negra evidencia a alta concentração de poluentes carreadas pelo riacho Maceió (Fortaleza/CE). 
Foto 15 Exemplo de jardim de chuva formado por uma depressão topográfica. O uso de vegetação arbustiva contribui para o aumento da eficiência do sistema. Local: St. Mary's Greek Orthodox Church, Minneapolis,

Foto 16 Exemplo de jardim de chuva formado por uma depressão topográfica. O uso de vegetação arbustiva contribui para o aumento da eficiência do sistema. Local: St. Mary's Greek Orthodox Church, Minneapolis,

Foto 17 Exemplo de biovaleta tratada apenas com tapete de grama. Local: Floriade, Venlo, Holanda.

Foto 18 Exemplo de biovaleta tratada com gramíneas diversas de tamanhos variados. Local: Floriade, Venlo, Holanda.

Foto 19 Exemplo de biovaleta tratada com vegetação arbustiva cuja função é captar e conduzir as águas pluviais de um estacionamento e via de acesso. Local: Calhoun Parkway, Minneapolis, EUA.

Foto 20 Exemplo de lagoa pluvial resultado do projeto Southwest Lake Calhoun Wetland Ponds, promovido pelo Minnehaha Creek Watershed District (MCWD).

Foto $21 \quad$ Exemplo de ilha flutuante.

Foto 22 Representação esquemática das ilhas flutuantes para suporte de vegetação ripária. Abaixo, exemplo da aplicação da tecnologia em um canal em Manila, capital das Filipinas.

Foto 23 Exemplos de pavimentação drenante.

Foto 24 Exemplo de poço de infiltração. Local: St. Mary's Greek Orthodox Church, Minneapolis, EUA.

Foto 25 Cobertura verde ondulada da École des Ponts ParisTech.

Foto 26 Cobertura verde ondulada da École des Ponts ParisTech.

Foto 27 Modelo de drenagem das águas pluviais criado pelo Minnesota Landscape Arboretum de cunho educacional.

Foto 28

Conjunto de reservatórios que recebem as contribuições das diferentes áreas correspondentes de estacionamento.

Foto 29 Grelhas de captação com trincheiras de infiltração presentes na Áreas 02 possuem contribuição significativa para a redução do volume de escoamento superficial.

Foto 30

Reservatórios 04 e 05 recebem as maiores contribuições de escoamento superficial por corresponderem às áreas mais impermeabilizadas. 
Foto 31 Uma biovaleta vegetada adjacente ao modelo recebe toda a água excedente nos casos de transbordamento.

Foto 32 Faixas de separação dasdiferentes áreas de contribuição.

Foto 33 Jardins de chuva já fazem parte do quotidiano da cidade de Portland, no Oregon-EUA.

Foto 34 Seattle SEA Street é exemplar no uso de biovaletas em um trabalho de retrofit de uma rua para melhor manejo de suas águas pluviais.

Foto $35 \quad$ Modelo experimental executado na Cidade Universitária da USP. Acima, aspecto dos jardins em fase inicial de implantação (dezembro/2011). Abaixo, aspecto dos mesmos jardins dois anos depois (março/2014).

Foto 36 Modelo experimental executado na Cidade Universitária da USP. Acima, aspecto dos jardins em fase inicial de implantação (dezembro/2011). Abaixo, aspecto dos mesmos jardins dois anos depois (março/2014).

Foto 37 Lagoa da Precabura (Eusébio/CE) e sua relação com a cidade de Fortaleza.

Foto 38 Av. Chanceler Edson Queiroz (Fortaleza/CE).

Foto 39 Av. Chanceler Edson Queiroz (Fortaleza/CE).

Foto $40 \quad$ Av. Chanceler Edson Queiroz (Fortaleza/CE).

Foto 41 Canal da avenida Aguanambi (Fortaleza/CE).

Foto 42 Leito concretado do canal da avenida Eduardo Girão (Fortaleza/CE), em sua confluência com o canal da avenida Aguanambi.

Foto 43 Apesar das estratégias de aumento de velocidade do escoamento o assoreamento do canal persiste, fruto do grande volume de sedimentos e lixo carreados durante as chuvas. Local: Canal da Avenida Aguanambi (Fortaleza/CE).

Foto 44 Afluente do riacho Parreão (Fortaleza/CE) com leito concretado.

Foto 45 Afluente do riacho Parreão (Fortaleza/CE) em trecho que corta propriedade privada.

Foto 46 O rio Pajeú (Fortaleza/CE) em trecho que corta o centro da cidade. 
Foto 49 Riacho Maceió (Fortaleza/CE) em trecho próximo a sua foz.

Foto 50 Rio Cocó é componente da maior bacia hidrográfica do território de Fortaleza.

Foto 51 Rio Coaçu em região próxima ao município de Eusébio/CE.

Foto 52 Riacho Parreão no trecho que corta o parque.

Foto 53 Os processos erosivos naturais do rio não constituem problemas para a solução adotada.

Foto $54 \quad$ Ponte sobre o rio acontece nos trechos mais estreitos do leito.

Foto $55 \quad$ Leito maior do riacho definido especialmente na porção sudeste do parque possui relevante papel na regulagem da vazão e promoção da infiltração no solo.

Foto 56 Primeiras obras realizadas para a implantação do Parque Rachel de Queiroz repetiu as corriqueiras soluções de concretagem do leito do rio, viabilizando a utilização de suas margens para ampliação do sistema viário.

Foto 57 Artificialização do leito não condiz com os princípios de um parque urbano contemporâneo seja pela ótica da ecologia, seja por questões estéticas.

Foto $58 \quad$ Maior obra hidráulica executada na primeira etapa de obras do parque criou imensa lagoa que ocupou quase a totalidade da área verde disponível.

Foto 59 Maior obra hidráulica executada na primeira etapa de obras do parque criou imensa lagoa que ocupou quase a totalidade da área verde disponível.

Foto 60 Aspecto das margens em concreto que definem a lagoa criada.

Foto $61 \quad$ Obras de aterro e concretagem das margens.

Foto 62 Após construção da lagoa a área verde resultante se limita a estreita faixa gramada.

Foto 63 Aspecto adquirido pelo riacho no trecho contemplado pela $2^{a}$ etapa da intervenção. natureza no resultado final. 
Foto 65 Pavimentação dos passeios e praças do campus sendo executadas em placas drenantes.

Foto 66 Piso ecológico adotado para as vagas de estacionamento do campus.

Fotos da obra em março/2016.

Foto 67 Configuração da pavimentação do estacionamento de visitantes. Circulação em piso intertravado pré-moldado de concreto e vagas pavimentadas com piso ecológico. Fotos da obra em março/2016.

Foto 68 Estrutura de captação e condução das águas pluviais executada junto ao passeio.

Foto 69 Aspecto do elemento de captação e condução das águas pluviais para os jardins de chuva (ainda em processo de implantação)

Foto $70 \quad$ Algodão-bravo - Ipomoea carnea.

Foto 71 Samambaia-gigante-do-brejo-Acrostichum aureum.

Foto 72 Piriquiti - Canna glauca.

Foto 74 Torém - Cecropia pachystachya.

Foto $76 \quad$ Licuri - Syagrus coronata.

Foto 77 Guajiru-Chrysobalanus icaco.

Foto $78 \quad$ Catolé - Syagrus cearensis.

Foto 79 Pau-branco - Cordia oconcalyx.

Foto $80 \quad$ Barriguda - Ceiba glaziovii.

Foto $81 \quad$ Juazeiro - Ziziphus joazeiro.

Foto 82 Pereiro-Aspidosperma pyrifolium.

Foto $83 \quad$ Pau-d'arco-amarelo - Tabebuia serratifolia. 
Foto 87 Cercamento que delimita terreno do campus corta área verde remanescente em solução que quebra a continuidade ecológica da região para diversos seres vivos.

Foto 89 Jardins de chuva do estacionamento principal com vegetação recém implantada.

Foto 90 Solução final para o dissipador de energia no lançamento das águas pluviais para os jardins de chuva.

Foto 91 Jardim de chuva do estacionamento já com vegetação implantada.

Foto 92 Jardim de chuva implantado com carnaúbas e vegetação arbustiva em seu interior.

Foto 93 Relação do jardim de chuva com outros trechos ajardinados ao redor do auditório.

Foto 94 Jardim de chuva com vegetação consolidada junto ao refeitório.

Foto 95 Primeiro jardim de chuva implantado já apresentando vigoroso crescimento da vegetação arbórea. jardim ainda em fase de implantação. 


\section{LISTA DE TABELAS}

$\begin{array}{lll}\text { Tabela } 01 & \text { Avaliação do SGE. } & 115\end{array}$

Tabela 02 Categoria 01 - Relação do edifício com seu entorno. 116

\begin{tabular}{ll} 
Tabela 03 & Níveis de avaliação - Gestão da Água. \\
\hline
\end{tabular}

Tabela $04 \quad$ Cálculo de intensidade das chuvas. 122

Tabela 05 Vazão de escoamento do terreno. 123

$\begin{array}{lll}\text { Tabela } 06 & \text { Volume de acúmulo das bacias. } & 125\end{array}$

Tabela 07 Volume de armazenamento das unidades de retenção. 126 



\section{LISTA DE MAPAS}

Mapa 01 Mapas temáticos desenvolvidos por McHarg para análise das potencialidades do território.

Mapa 02 Município de Fortaleza e regiões circunvizinhas, com destaque para os recursos hídricos ainda visíveis na paisagem da metrópole.

Mapa 03 Localização do campus da Fiocruz dentro da Região Metropolitana de Fortaleza.

Mapa 04 Localização do Campus da Fiocruz junto a lagoa da Precabura. 



\section{LISTA DE GRÁFICOS}

Gráfico 01 Impactos da urbanização e consequente impermeabilização do solo nas taxas de infiltração e escoamento superficial.

Gráfico 02 Comportamento do caudal de um curso hídrico antes e após ocupação e impermeabilização de sua bacia de contribuição.

Gráfico 03 Adaptado de Maksimovic.

Gráfico 04 Novas soluções de drenagem para o aeroporto Tempelhof.

Gráfico 05 Perfil Ambiental do Campus da Fiocruz definido na fase Programa da Certificação AQUA.

Gráfico 06 Esquema de condução das águas pluviais idealizado na fase de anteprojeto.

Gráfico 07 Configuração final do sistema de drenagem adotado. 



\section{LISTA DE PLANTAS}

$\begin{array}{lll}\text { Planta } 01 & \text { Planta do parque Parreão. } & 103\end{array}$

Planta 02 Configuração do relevo condicionou o caimento das vias do campus. 121

Planta 03 Síntese do esquema de condução subterrânea das águas pluviais 121 elaborado no estudo preliminar.

Planta 04 Subdivisão da área do campus em 5 bacias para cálculo das vazões finais de escoamento (runoff).

Planta 05 Definição das unidades de retenção nas áreas livres do complexo adjacentes às áreas de contribuição (vias e passeios). 



\section{LISTA DE ORGANOGRAMAS}

Organograma 01 Planejamento integrado Verde e Azul. 



\section{LISTA DE SIGLAS}

\begin{tabular}{ll} 
AQUA & Alta Qualidade Ambiental \\
CUASO & Cidade Universitária Armando de Salles Oliveira \\
CWA & Clean Water Act \\
DBO & Demanda Bioquímica de Oxigênio \\
EPA & Environmental Protection Agency \\
FAU & Faculdade de Arquitetura e Urbanismo \\
FCTH & Fundação Centro Tecnológico de Hidráulica \\
FUNDEP & Fundação de Desenvolvimento da Pesquisa \\
FUPAM & Fundação para a Pesquisa em Arquitetura e Ambiente \\
IEV & Infraestrutura verde \\
ISO & International Organization for Standardization \\
LEED & Leadership in Energy and Environmental Design \\
LID & Low Impact Development \\
MCWD & Minnehaha Creek Watershed District \\
PITS & Polo Industrial e Tecnológico da Saúde \\
PROCEL & Programa Nacional de Conservação de Energia Elétrica \\
QAE & Qualidade Ambiental do Edifício \\
SGE & Sistema de Gestão do Empreendimento \\
TVA & Tennessee Valley Authority \\
USP & Universidade de São Paulo \\
\hline
\end{tabular}


CAPÍTULO I

DA NATUREZA DA CIDADE AO PLANEJAMENTO ECOLÓGICO: FORMAS DE PENSAR A CONSTRUÇÃO DO URBANO

1.1 A ecologia da paisagem e planejamento

CAPÍTULO II

AS INFRAESTRUTURAS VERDES NO CONTEXTO

DAS ÁGUAS URBANAS

2.1 Infraestruturas verdes na escala do manejo das águas 64

2.1.1 Jardim de chuva 67

2.1.2 Biovaleta ou Valas de Infiltração Vegetadas 68

2.1.3 Lagoa Pluvial 69

2.1.4 Ilhas flutuantes 70

2.1.5 Teto verde 71

2.1.6 Pavimentos Drenantes 72

2.1.7 Trincheiras ou Poços de Infiltração 73

$\begin{array}{ll}\text { 2.1.8 Grade Verde } & 74\end{array}$

2.2 Investigação e prática na aplicação das Infraestruturas verdes $\quad 76$

2.2.1 Blue Green Dream 76

2.2.2 Minnesota Landscape Arboretum 81

2.3 Infraestruturas Verdes no Brasil $\quad 85$

2.3.1 Praça das Corujas 88

2.3.2 Modelo experimental de biorretenção 90 
CAPÍTULO III

CAMPUS FIOCRUZ CEARÁ: PRIMEIRAS APLICAÇÕES

DAS INFRAESTRUTURAS VERDES NO CONTEXTO DO SEMIÁRIDO.

3.1 Urbanização $\mathrm{x}$ recursos naturais: uma breve caracterização

das últimas intervenções na região metropolitana de Fortaleza.

3.1.1 Parque Parreão

3.1.2 Parque Rachel de Queiroz

3.2 Projeto para o Campus da Fiocruz no Ceará

3.3 Certificação ambiental na construção civil

3.4 O projeto de drenagem

3.4.1 Dimensionamento do sistema

3.5 Infraestruturas verdes: uma solução possível

3.6 Discussão

3.7 Conclusão 



\section{Apresentação}

O presente trabalho tem como foco a investigação do manejo das águas urbanas, tratando especificamente das soluções de Infraestruturas Verdes (IEV) e sua aplicação dentro do recorte geográfico da região metropolitana de Fortaleza.

O tema estudado se insere no campo da Ecologia da Paisagem ao buscar uma linha de abordagem que responda de forma adequada aos problemas ambientais relacionados à fragmentação de habitats, diminuição das áreas verdes e gestão da água, especialmente considerando as múltiplas escalas em suas análises e a busca do entendimento das relações estabelecidas entre áreas heterogeneamente compostas. Lidando de forma mais aprofundada sobre o tema das águas urbanas, o estudo explora as soluções de IEV enquanto mecanismos capazes de promover uma mitigação, do impacto causado pela urbanização sobre o ciclo hidrológico em determinada região.

Já bastante difundida em diversos países como Estados Unidos, Canadá, Austrália, China, Holanda, entre outros; aplicação de seus contextos na requalificação dos espaços urbanos no Brasil é muito recente, e as pesquisas em torno da aplicação de suas práticas ainda se encontram em fases iniciais de desenvolvimento. Os diferentes climas tropicais que predominam no país, assim com todas as suas variações de relevo, solo, temperatura, pluviometria, regime de ventos, vegetação etc., exigem que a aplicação das tecnologias de biorretenção seja corretamente adequada às especificidades locais, tendo em vista a matriz orgânica que Ihe serve de suporte e as diferentes relações ecossistêmicas que se estabelecem pela sua implantação.

Da mesma forma, é de fundamental importância, para o êxito da aplicação dessas práticas, a compreensão da realidade urbana, cultural e ambiental brasileira, as quais balizarão as estratégias de remediação a serem enfrentadas pelas diferentes soluções infraestruturais, sem deixar de enfrentar as questões relacionadas às diferentes paisagens.

Como citado inicialmente, o recorte geográfico escolhido para trabalho é o da região metropolitana de Fortaleza, a qual tem passado, nas últimas décadas, por um acelerado processo de expansão urbana acompanhada por agravamento significativo dos proble- 
mas ambientais relacionados à ocupação desordenada de leitos de rios e aterros de lagoas, dentre outros. Assim como nas demais grandes cidades do país, a relação da expansão da malha urbana com os rios em seu território tem se dado de forma conflituosa e baseada em práticas ambientalmente predatórias pelo simples desconhecimento da importância dos recursos hídricos como componentes fundamentais para o equilíbrio do ecossistema urbano.

Além dessas questões circunstanciais, a pesquisa explora a aplicação da tecnologia na região litorânea do estado do Ceará como forma de ampliar a produção científica nacional sobre o tema pela sua investigação em um contexto geoambiental ainda não estudado sob esse enfoque, especificamente na área de ocorrência do clima semiárido brasileiro. As particularidades do clima, do solo e da vegetação locais trazem novos desafios a serem respondidos pelo arcabouço técnico conhecido do tema, e seguramente trazem contribuições significativas para a constituição de uma tecnologia brasileira de manejo das águas urbanas baseadas em tecnologias de alto desempenho e baixo impacto.

Para tanto, a pesquisa toma como objeto de estudo de caso o projeto de Infraestruturas Verdes (IEV) desenvolvidas para o campus da Fiocruz no Ceará, o qual se utiliza desses recursos técnicos para remediar os impactos nocivos da construção do campus sobre as taxas de permeabilidade do solo e qualidade das águas pluviais do empreendimento a serem lançadas no riacho próximo. 0 projeto constitui um dos primeiros exemplos de aplicação dos conceitos de Infraestruturas Verdes no estado do Ceará, especialmente considerando a sua escala de aplicação, e sua concepção foi desenvolvida pelo autor da presente dissertação.

Ao longo dos últimos 3 anos o projeto de drenagem do campus da Fiocruz Ceará e a pesquisa de mestrado se alimentaram mutuamente, evoluindo em suas soluções na medida em que prática e teoria foram continuamente confrontadas. Ao receber a tarefa de elaboração do projeto paisagístico para o Campus da Fiocruz, ainda no ano de 2013, o autor já iniciava seus estudos preliminares sobre os conceitos de Infraestruturas Verdes e de Tecnologias de Baixo Impacto, o que estimulou uma imediata identificação do potencial de aplicação dessas soluções no projeto do campus, mesmo que isso não fizesse parte do escopo original do projeto solicitado. A partir de então, o projeto paisagístico e seu sistema de drenagem em desenvolvimento tornou-se o tema de investigação.

Os documentos técnicos elaborados ao longo dos projetos conceituais, básicos e executivos nas diversas disciplinas envolvidas foram desenvolvidos com base no aprofundamento do referencial teórico sobre o tema, e amadurecido a partir do conhecimento adquirido nas visitas técnicas realizadas em São Paulo e Minneapolis (EUA) a modelos de infraestruturas verdes implantados e em funcionamento, atividades estas desenvolvidas já no âmbito do mestrado da FAU-USP. Todo o conhecimento produzido nesse processo foi organizado de forma a apresentar como a assimilação das pesquisas sobre IEV levou às propostas adotadas para o projeto do Campus, não só apresentando as soluções técnicas desenvolvidas, mas relacionando-as ao arcabouço histórico, teórico e conceitual que Ihe origina. 
Posto isso,o trabalho buscou contextualizar a disseminação dos conceitos contemporâneo de IEV dentro de uma perspectiva histórica, enquanto fruto de uma evolução do conhecimento sobre a natureza do espaço urbano. Para tanto, o capitulo 01 remete ao surgimento da cidade industrial, a qual trouxe novos desafios de planejamento do território em função da vertiginosa perda de qualidade que se verificou em seus espaços. São destacadas, portanto, as notáveis contribuições de Ebenezer Howard e Olmstead como precursoras na proposição de novas formas de planejar e construir as cidades em sintonia com a natureza a qual pertence.

Já sobre o século XX, são destacadas as contribuições teóricas de lanMcHarg e Spirn para disseminação dos conceitos fundamentais de um urbanismo ecológico que hoje é trabalhado sob diversas abordagens, dentre as quais temos a ecologia da paisagem e suas diversas interpretações e seus rebatimentos na aplicação prática. A revisão teórica sobre ecologia da paisagem no primeiro capítulo se fez necessária para a compreensão do contexto em que se desenvolveram os princípios das infraestruturas verdes, fruto de uma nova postura assumida para mitigar o impacto que as intervenções humanas causam na dinâmica hídrica.

Essa relação é melhor trabalhada no Capítulo 02, o qual destaca o entendimento da ecologia da paisagem sob o enfoque da relação entre a urbanização e a dinâmica hídrica de um território. São apresentados os impactos negativos que o adensamento construtivo e a impermeabilização do solo causam nas taxas de infiltração, escoamento superficial e na qualidade das águas. Impactos esses, cada vez mais potencializados por um modelo predatório de urbanização e equivocadas estratégicas manejo das linhas de drenagem nos espaços urbanos. Na compreensão das raízes dos problemas, são apresentadas, portanto, as soluções adotadas pelas infraestruturas verdes para reversão desse quadro.

Um rápido panorama do estado da arte no contexto internacional é trabalhado através da apresentação de exemplos atuais de pesquisas como o Blue, Green Dream, em curso na Europa, e um modelo experimental americano que comprova tecnicamente o desempenho de diferentes formatações de infraestruturas verdes adotadas para um mesmo componente urbanístico. Da mesma forma, é apresentado um breve panorama do estado da arte no contexto nacional, apresentando os primeiros passos de aplicação desse conceitos no contexto paulistano, seja na obra de requalificação paisagística da Praça das Corujas, seja nos resultados obtidos através de um modelo experimental desenvolvido pela USP ou na adoção das infraestrurturas verdes como espinha dorsal para os trabaIhos de planejamento urbanístico/paisagístico.

Por fim, o capítulo 03 dedica-se a apresentação do projeto de Infraestrutura Verde concebido para o Campus da Ficruz Ceará, evidenciando a evolução e maturação da concepção nas diferentes etapas projetuais, os desafios técnicos enfrentados pelo ineditismo do conceito no contexto da construção civil local e as soluções finais adotadas, evidenciando o poder que as estratégias de urbanismo resiliente possuem para moldar-se às diversas condições em que se implanta. 

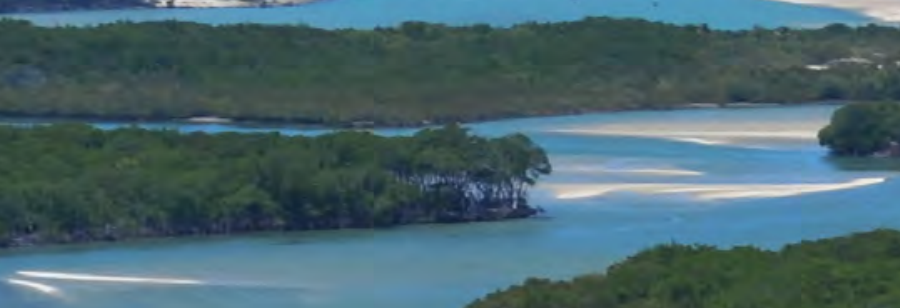

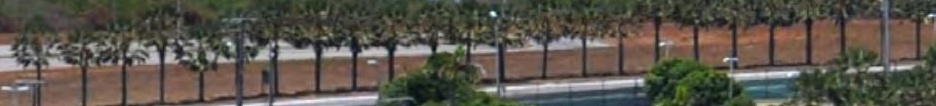

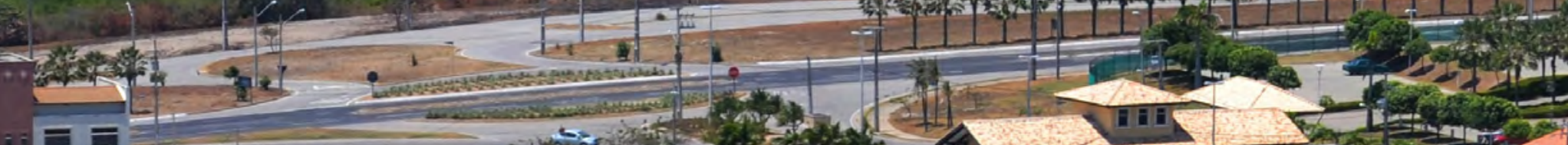
DT

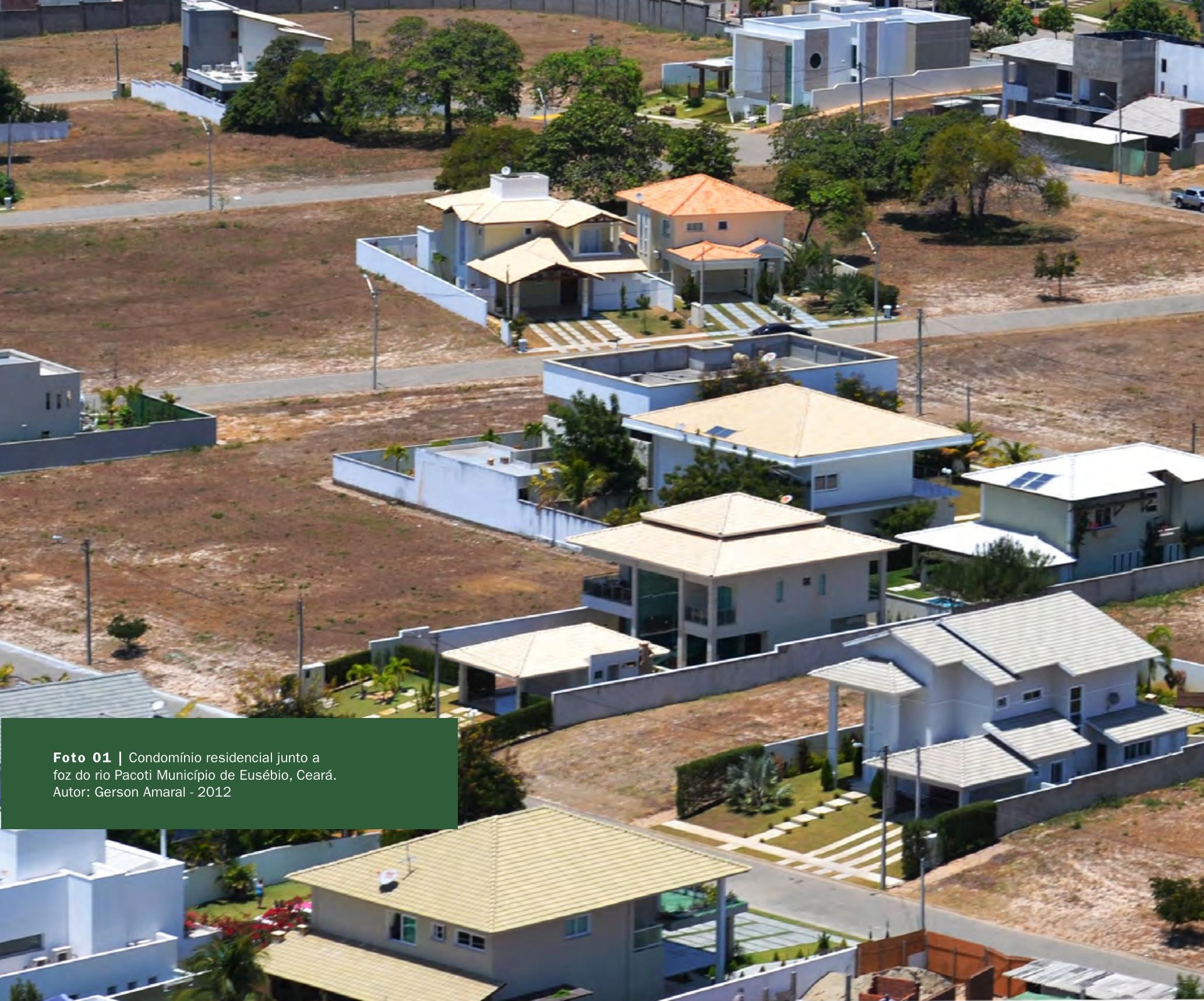


CAPÍTULO I

\section{Da natureza da cidade ao planejamento ecológico: \\ Formas de pensar a construção do urbano}

O final do século XX e o início do século XXI são marcados por grandes transformações no campo do planejamento urbano, o qual vem, ao longo das últimas décadas, construindo novos caminhos para o enfrentamento dos desafios da cidade contemporânea. Sobre essa mudança, já evidente no final dos anos 1980, afirma Argan:

\footnotetext{
"De fato, as teorizações urbanísticas mais recentes desenvolveram-se em sentido ecológico e em sentido estruturalista; mas tanto a primeira pesquisa, iniciada por Lynch, quanto à segunda, iniciada por Alexander, dão como superada a concepção racionalista do urbanismo como subdivisão, distribuição, organização e construção do espaço. Esse termo, que implicava necessariamente a ideia da relação entre ego e natureza, foi sucedido pelo de ambiente, que não admite, evidentemente, nenhuma definição racional ou geométrica e que se concretiza em um conjunto de relações e interações entre a realidade psicológica e realidade física." (ARGAN, 2005, p. 215)
}

O urbanismo contemporâneo caracteriza-se por um novo olhar sobre a construção do espaço vivido. Em uma época em que a tecnologia permite o mapeamento de todo o planeta sintetizado em um modelo tridimensional com todas as suas in- 


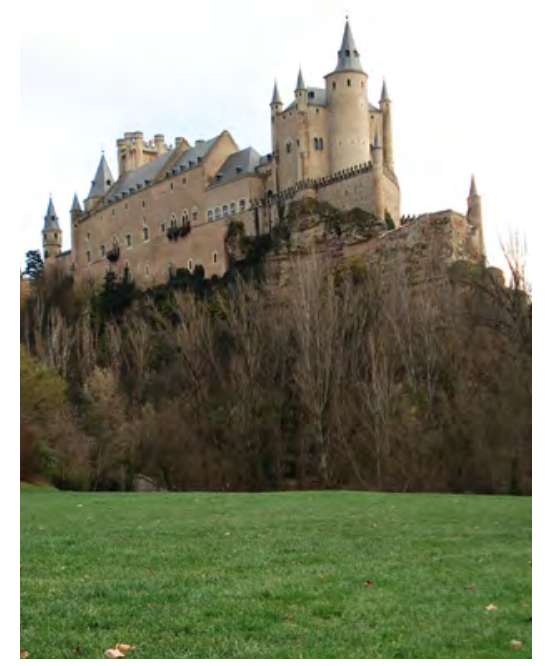

Foto 02 | Alcazar de Segóvia (séc XII) implantado estrategicamente sobre um penhasco na confluência de dois rios. Exemplo de aproveitamento das características naturais do sitio para potencializar as funções de defesa da cidade e domínio do território.

Autor: Gerson Amaral - 2006 formações acessíveis por apenas um click, a relação com a natureza se estabelece sobre bases muito sólidas, pelo conhecimento cada vez mais amplo dos impactos das ações humanas sobre o planeta.

Nos primórdios da humanidade, a domesticação dos animais e das plantas coincidiu com a domesticação da paisagem natural, pelo domínio da modelagem da terra e da água seja para construção de utensílios, seja para construção da casa, do vale de irrigação ou do canal, dando origem aos primeiros assentamentos humanos (MUMFORD, 1998). A história nos revela que a domesticação da paisagem, antes de tudo, significa o conhecimento apurado da configuração física e dos processos incidentes sobre o meio, condicionando a escolha dos melhores sítios para fixação de comunidades e tomando-os como aliados para melhor desempenho das funções pretendidas. Constatamos, então, que os assentamentos urbanos estão tradicionalmente vinculados a um recurso hídrico, para provimento seguro e contínuo de água, às férteis planícies próprias ao cultivo e pecuária, às enseadas protegidas para o desenvolvimento do comércio marítimo, aos promontórios escarpado para fins bélicos ou refúgio seguro contra inimigos, etc. A cidade tradicional, portanto, incrementa e compõe a paisagem, estabelecendo uma relação simbiótica com o sítio, respeitando aquilo que Ihe é próprio, mas estabelecendo limites claros entre o construído (o artificial, o limitado, o conhecido, o dominado) e a natureza (o que estava além dos muros, o ilimitado, desconhecido, incontrolável) (ARGAN, 2005).

Impulsionada pela revolução industrial, essa lógica tradicional de produção e expansão das cidades foi radicalmente alterada desde o início do século XIX pela lógica capitalista que tendeu a desmantelar toda a estrutura da vida urbana e colocá-la em uma nova base impessoal: o dinheiro e o lucro (MUMFORD, 1998). A terra urbana, convertida em mercadoria, passou a ser produzida expandindo ilimitadamente suas fronteiras, pondo o lucro à frente do controle urbano. A definição dos arruamentos e o parcelamento do solo passaram a ser determinados pelo máximo aproveitamento econômico, relegando a um segundo plano as características de relevo, orientação dos ventos, hidrografia e a própria construção da paisagem. 
O crescimento das cidades passou a ser largamente induzido pela ampliação da malha viária e do sistema de distribuição de água, gerando uma cidade cada vez mais dispersa e amorfa, em contraste com os antigos núcleos urbanos compactos, e cada vez menos comprometida com a qualidade do ambiente que se produzia. Sobre isso afirma Munford:

\footnotetext{
"A lei do crescimento urbano, ditada pela economia capitalista, significou a inexorável destruição de todas as características naturais que deleitam e fortificam a alma humana em suas atividades diárias. Os rios eram transformados em esgotos [...], as zonas portuárias podiam ser tornadas inacessiveis para o transeunte, árvores antigas podiam ser sacrificadas e edifícios veneráveis postos abaixo em favor da velocidade do tráfego; mas, enquanto as classes superiores pudessem ir de carruagem passear no Central Park ou dar uma galopada matinal em Rotten Row, a falta de espaço para recreação e de beleza recreativa na cidade em geral não chegou a ser percebida." (MUMFORD, 1998, p. 462)
}

Nessa lógica de produção do espaço urbano, os elementos naturais, antes determinantes da configuração física e produção da paisagem, converteram-se em ruídos indesejáveis frente à ânsia de geração de um traçado ideal para conversão do solo em unidades monetárias de compra e venda: o lote. 0 desenvolvimento industrial do século XIX produziu um modelo de desenvolvimento da cidade que "penaliza e compromete igualmente sociedade e natureza” (LIMA, 2004), visto que se baseava na exploração intensiva dos recursos naturais ao mesmo tempo em que se produzia um espaço urbano degradado e poluído, não só nas periferias operárias, mas também nos bairros mais nobres.

Reagindo a degradante situação do espaço urbano que se produziu, esse período também foi caracterizado pelo aprimoramento da arte do saneamento e da higiene pública que passaram a balizar o desenvolvimento das cidades a partir de então. Tomando uso das mais diversas soluções técnicas de engenharia em desenvolvimento à época, transformações drásticas do meio 

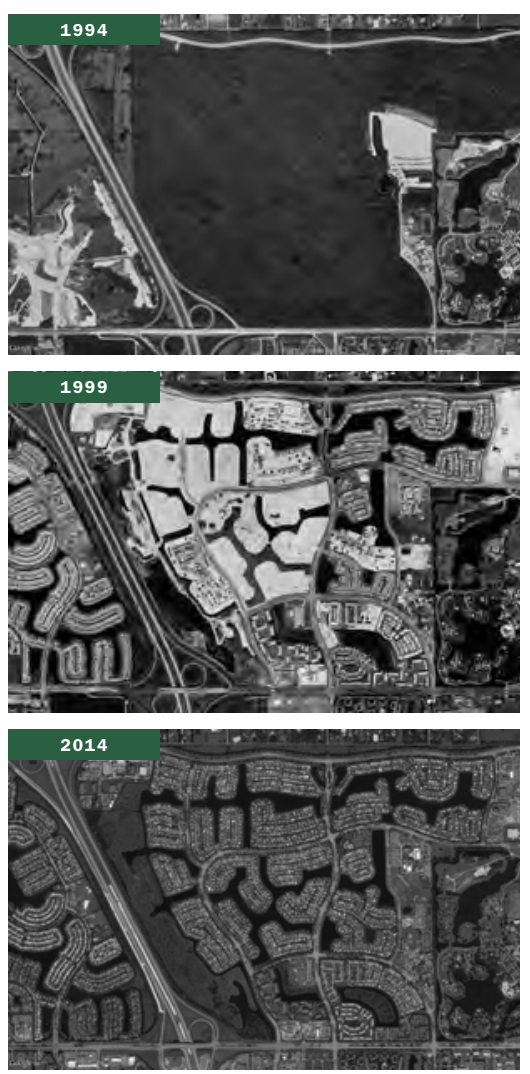

Fotos 03, 04 e 05 | Exemplo de transformação drástica de terras alagáveis para viabilizar a sua incorporação pelo mercado imobiliário. Pembroke Falls, Florida-EUA. Fonte: Google Earth (1994-1999-2014) físico como o corte ou total supressão de morros, o aterramento de vales e charcos, a drenagem de lagoas, a retificação ou tamponamento de leito de rios, etc., tornaram-se práticas vigentes de construção e melhoramento do espaço urbano. Enfim, todo esforço passou a ser empregado para a transformação do suporte físico a ponto do sítio ser plenamente incorporado ao mercado imobiliário vigente.

Os custos ambientais de tais práticas são altos. Para além da transformação das formas físicas do espaço natural, a negação da natureza na construção do espaço urbano desconsidera, e igualmente transforma, os processos bióticos e abióticos do local, trazendo impactos diretos sobre o solo, o ciclo hídrico, a qualidade do ar, a biodiversidade e o microclima. Sobre as consequências dessas transformações promovidas pela urbanização que nega a natureza, Anne Spirn afirma:

\footnotetext{
"Disregard of natural processes in the city is, always has been, and always will be both costly and dangerous. Many cities have suffered from a failure to take account of nature. [...] The cost of disregarding nature extends also to the quality of life. The newer parts of cities - across continents, climates, and cultures - are everywhere acquiring a boring sameness. The potential of the environment to contribute to a distinctive, memorable, and symbolic urban form is unrecognized and forfeited." ${ }^{5}$ (SPIRN, 1984, p. 10)
}

As perdas para a qualidade de vida das cidades são enormes. Importante destacar a importância que Spirn confere aos aspectos psicológicos e culturais dessa visão de produção de cidades, enfatizando a monotonia produzida pela eliminação das características naturais que tornam cada local único e especial. $\mathrm{A}$ aborserá caro e perigoso. Muitas cidades têm sofrido com a falta de consideração da natureza. [...] O custo de ignorar a natureza estende-se também para a qualidade de vida. Os novos trechos de cidades - em todos os continentes, climas e culturas - estão adquirindo, em todos os lugares, uma mesmice chata. O potencial do meio ambiente para contribuir para uma forma urbana distinta, memorável, e simbólica é desconhecida e desperdiçada." Tradução livre do autor. 
dagem de Spirn, na mesma linha inaugurada por McHarg em seu livro seminal Desing With Nature, desconstrói a concepção de cidade como algo que se desvincula completamente do meio natural, como se fosse possível a sua existência excluindo as características e processos próprios do meio ambiente onde se implantam. A busca pela transformação e controle da natureza, através das mais diversas soluções de infraestrutura (movimentações de terra, redes de abastecimento, drenagem, saneamento, pavimentação, etc.) tradicionalmente tem prezado pelo ocultamento máximo daquilo que é a lógica dos processos incidentes no meio físico. O ciclo hidrológico, as fontes de água potável, o destino do lixo e dos esgotos passaram a ser sistematicamente ocultados da paisagem na cidade, resultando em uma alienação da população quanto à compreensão da natureza e seus processos.

\footnotetext{
"Em suma, a configuração da terra foi uma parte integrante da configuração da cidade - e a precedeu. É essa íntima relação biotécnica que o homem moderno, com seus planos de substituição de complexas formas de terra e associações ecológicas por sucedâneos artificiais vendáveis, desfaz, com perigo para si próprio." (MUMFORD, 1998, p. 24)
}

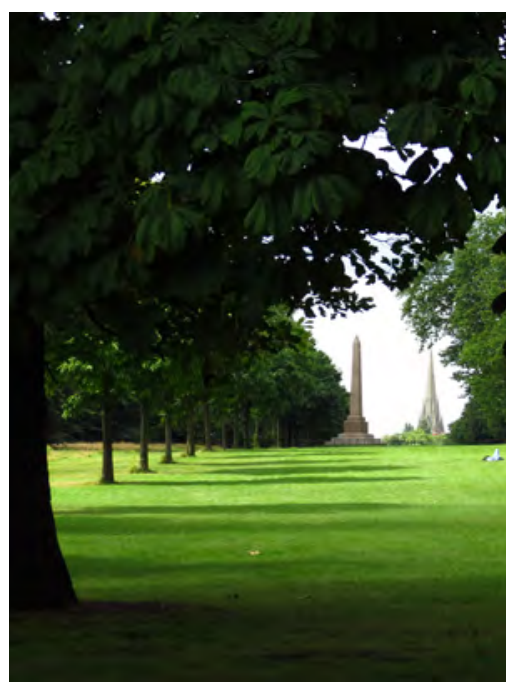

Foto 06 | No século XIX as áreas verdes dentro do espaço urbano ganharam importância, especialmente em Londres, pelos benefícios a saúde que um ambiente bucólico promove. Imagem: Hyde Park, Londres. Autor: Gerson Amaral - 2012
Ainda no século XIX, a cidade industrial, marcada pela poluição da água, do ar e sonora, e dos maus costumes, estabeleceu-se como antítese do campo, o qual passou a ser um local desejado, uma vez que possuía ar fresco e tranquilidade, promotora da saúde e bem estar. Por isso vimos o surgimento da valorização das áreas verdes pelos benefícios que o contato com a natureza trazia ao corpo e ao espírito. Essa procura pelo verde levou a valorização da conservação de bolsões de elementos naturais dentro do espaço urbano, com a função de melhorar a qualidade de vida de seus habitantes.

No bojo das ações dos ideais de salubridade urbana, vemos surgir os parques urbanos como o conhecemos nos dias atuais. É mais um passo na busca pela resolução do conflito que se estabeleceu entre cidade e natureza, cada vez mais evidente pelo aumento da velocidade de expansão das cidades e o tecnicismo que passou a pautar o seu desenvolvimen- 
to. Esse movimento também alimentou, dentre outras coisas, a proposta de Cidades-Jardins de Ebenezer Howard que propunha o limite ao crescimento dos núcleos urbanos delimitados por cinturões verdes agrícolas.

A proposta de Howard buscava assegurar a qualidade das grandes cidades sem perder os benefícios do contato com a natureza, estabelecendo um equilíbrio entre cidade e campo em um arranjo que foi de grande contribuição para a história do planejamento urbano por inserir no trato do planejamento urbano, "critérios biológicos essenciais de equilíbrio dinâmico e equilíbrio orgânico" (MUMFORD, 1998, p. 557). Para além da mera introdução de áreas verdes e espaços abertos, a contribuição da Cidade Jardim propunha de novo o tratamento da complexidade do crescimento urbano, "mediante uma organização capaz de estabelecer um equilíbrio e a autonomia e de manter a ordem, a despeito da diferenciação, e a coerência e unidade, a despeito da necessidade de crescimento." (Idem, op. Cit., p. 560)

A idealização de novas cidades urbanística e ecologicamente equilibradas propostas por Howard não dava conta, contudo, de soluções para aquelas cidades já consolidadas e marcadas por um quadro de insalubridade urbana e conflitos com o meio natural. Problemas como ocupações de áreas alagáveis e poluição dos recursos hídricos continuavam a ser enfrentados exclusivamente sob a ótica das técnicas de infraestrutura, ainda sob a lógica de viabilizar a contínua expansão urbana e ocupação máxima e predatória do território.

Podemos elencar como importante precedente histórico das cidades-jardins e do movimento de criação de parques em várias cidades do mundo a vasta produção do Frederick Law Olmstead, que, nos Estados Unidos do segundo quartel do século XIX, foi autor de parques urbanos que até hoje são importantes referências na área. 


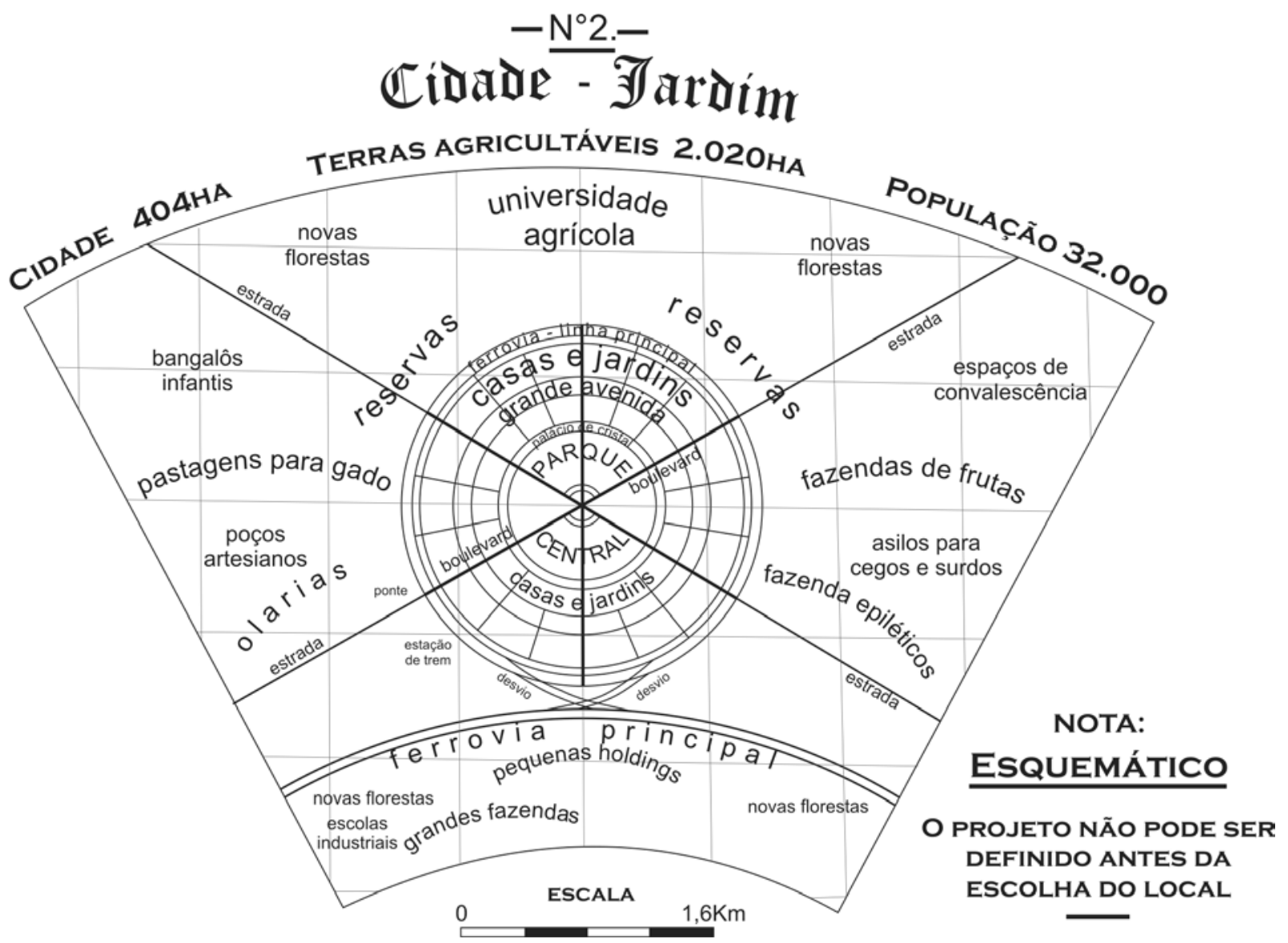

Desenho 01 | 0 esquema concebido por Ebenezer Howard onde mostra a distribuição geral da Cidade-Jardim, com destaque ao uso de baixas densidades e valorização das áreas verdes dentro da cidade. Fonte: Urbanidades. Banco de Imagens de urbanismo e planejamento urbano. Disponível em: <http:// urbanidades.arq.br/bancodeimagens/ displayimage. php?pos=-12> Acesso em: 14/02/2016. 


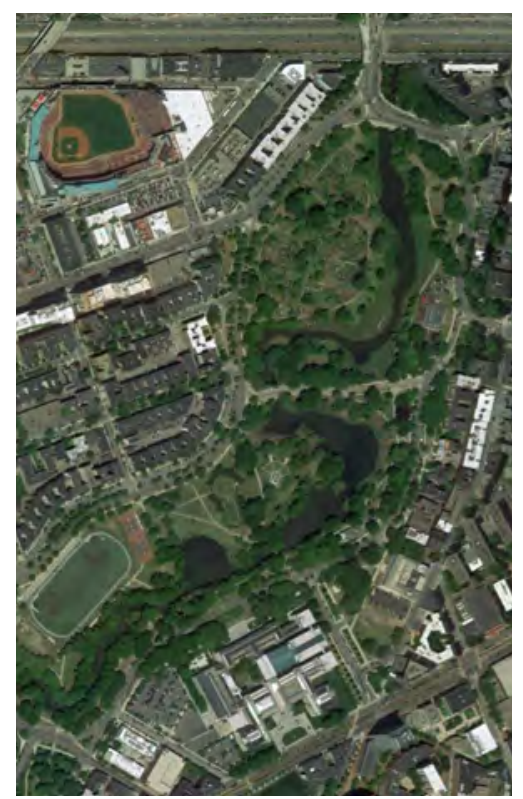

Foto 07 | The Fens, trecho do Emerald Necklace, em sua configuração atual. Fonte: Google Earth. Acesso: 09/03/2015
Um dos mais emblemáticos exemplos é o caso do Emerald Necklace (Colar de Esmeraldas) em Boston, o qual se trata de uma intervenção paisagística na periferia da cidade criando uma sequencia de parques interligados por parkways ${ }^{6}$.

A proposta de Olmstead para o parque surge como solução integrada de saneamento e controle de cheias de uma região da cidade historicamente marcada por intensas transformações do relevo e hidrografia, como desmontes de morros para criação de aterros sobre planícies de inundação e sobre a baía. Sua mais notável intervenção constitui o parque chamado de Fens, o qual foi criado pela dragagem de planícies alagáveis para criação de uma zona de amortecimento de cheias, controlando a vazão do rio Charles, com tratamento paisagístico adequado às variações do nível da água. A intervenção passou a evitar alagamentos dos bairros às margens do rio, controlando a entrada e saída de água, e regulando o fluxo através de desenhos sinuosos e margens taludadas. (SPIRN, 1984)

O Colar de Esmeraldas de Olmstead é inovador por associar solução de infraestrutura sanitária e controle hídrico com uma proposta de requalificação urbana e criação de espaços livres de lazer, propondo um atrativo parque urbano que reconfigurou toda uma zona da cidade de Boston. A infraestrutura aqui foi promotora da requalificação da paisagem da cidade, em uma solução eficiente sob diversos pontos de vista: ambiental, urbanístico e paisagístico; que tem inspirado, ao longo do ultimo século, mudanças significativas na forma de lidar com as questões de saneamento e requalificação dos espaços livres públicos, especialmente quando associados a recursos hídricos.

Mas foi apenas na segunda metade do século XX que uma visão ecossistêmica passou a fundamentar as ações de intervenção nas cidades e a promover mudanças em sua configuração

\footnotetext{
6 Parkway é uma tipologia paisagística criada por Olmsted e Vaux, em 1866, no projeto do Prospect Park, no Brooklyn, em Nova York. Originalmente designava uma via larga densamente arborizada, com tratamento cênico, conectada a um parque. Posteriormente, a palavra incorporou outra qualidade: a segregação de determinados tipos de veículos. In: BONZI, Ramon. Emerald Necklace: infraestrutura urbana projetada como paisagem. LABVERDE, São Paulo, v. 1, n. 9, p. 112, 2014.
} 
seguindo princípios ambientais e ecológicos. À medida que os conceitos e reflexões sobre o tema eram discutidos, novas teorias começaram a surgir e geraram produções de grande importância para a disseminação desses conceitos. Um dos mais significativos é o livro Design with Nature de lan McHarg, lançado em 1969, que, defendendo um planejamento holístico do uso do território em substituição ao desenvolvimento desordenado, mostra como é possível conciliar as aspirações da sociedade contemporânea com a preservação dos processos ecológicos existentes, próprios de um território. Sua metodologia se utiliza de mapas temáticos transparentes (overlays), que permitem uma interpretação cruzada, possibilitando a identificação das potencialidades de cada área para os diferentes graus de interferência humana. (PELLEGRINO P. R., 2000) A busca pela preservação dos processos ecológicos implica não só na obtenção de uma qualidade de vida para a população, como também valorização das próprias características do meio físico.

A abordagem de McHarg foi trabalhada, com foco no espaço urbano, por Anne Whiston Spirn em seu livro 0 Jardim de Granito: Natureza urbana e Design Humano (1984). Este livro foca na ecologia de áreas urbanas abordados segundo tópicos: a matriz de ruído, poeira, poluição, insolação, escoamento de águas pluviais, vento e vida silvestre, que podem ser mitigados e melhorados através do tratamento da paisagem urbana.

Os livros de McHarg e de Spirn constituem valiosas contribuições para a maturação de uma abordagem que ficou conhecida por Ecologia da Paisagem. O primeiro a citar esse termo no âmbito científico foi um biogeógrafo alemão Carl Troll em 1939, o qual o definiu como a observação das inter-relações da biota (incluindo o homem) com o seu ambiente, formando um todo, sob a ótica da paisagem, entendida como a espacialidade heterogênea do espaço onde o homem habita. 0 termo, atualmente, pode ser atribuído a duas vertentes distintas de pensamentos: uma dita "geográfica", originada na Europa por Carl Troll e por pesquisadores essencialmente geógrafos da Europa Ocidental e Alemanha; e outra dita "ecológica", bem mais recente (década de 1980), influenciada por biogeógrafos e ecólogos americanos. A corrente geográfica foca nas interações do homem com o seu meio ambien- 
te, já a corrente ecológica se preocupa na compreensão das consequências do padrão espacial nos processos ecológicos. (METZGER, 2001)

Na busca de superação dessa polaridade entre as duas correntes, com o objetivo de unificar os conceitos básicos da ecologia da paisagem e estabelecimento de um sólido arcabouço teórico comum, Metzger toma como elemento central na discussão o conceito de Paisagem, a qual define como "um mosaico heterogêneo existente para pelo menos um fator, segundo um observador e numa determinada escala de observação". A diferença básica entre as duas correntes da ecologia da paisagem anteriormente citadas residiria, segundo Metzger, em qual seria o observador do mosaico heterogêneo que define a paisagem. Na abordagem geográfica, é adotado o olhar do homem, das suas necessidades, anseios e planos de ocupação territorial. Por sua vez, na abordagem ecológica é adotado o olhar das espécies estudadas (animais ou vegetais) ou suas comunidades, suas características biológicas e seus requerimentos em termos de área de vida, alimentação, abrigo e reprodução, dentro de um mosaico formado por um conjunto de habitats mais ou menos favoráveis para a(s) espécie(s). (METZGER, 2001)

Ainda pelo mesmo autor, a consideração deste ou aquele observador na definição da paisagem a ser trabalhada consequentemente trás o aspecto das múltiplas escalas possíveis de abordagem pela ecologia da paisagem, visto que a definição da dimensão de abordagem subordina-se a capacidade de deslocamento e interação das espécies consideradas, tomando ciência de que os padrões espaciais influenciam os processos ecológicos. As interações espaciais estabelecidas entre as unidades da paisagem constituem, portanto, o ponto central da ecologia da paisagem.

Coadunando-se a definição de Metzger, para Pellegrino Ecologia da Paisagem pode ser assim definida:

"Sob uma ótica mais pragmática, pode-se considerar a paisagem como um conjunto interativo de manchas, corredores e matrizes, e a Ecologia da Paisagem como a ciência que estuda os 
processos de fragmentação, isolamento e conectividade realizados pelo homem nos ecossistemas naturais para investigar a influência de padrões espaciais sobre os processos ecológicos." (PELLEGRINO P. R., 2006)

Na abordagem de Pellegrino o homem é peça chave na abordagem da Ecologia da Paisagem, visto que nos dias atuais os impactos da ação do homem sobre o meio físico são observados a nível global, influenciando em qualquer que seja a escala de análise abordada. Seus conceitos podem ser aplicados em qualquer padrão de ocupação do território, da cidade ao campo, do deserto a floresta.

Segundo DRAMSTAD (1996)

"this living system exhibits three broad characteristics: structure, functioning, and change. Landscape structure is the spatial pattern or arrangement of landscape elements. Functioning is the movement and flows of animals, plants, water, wind, materials, and energy through the structure. And change is the dynamics or alteration in spatial pattern and functioning over time."7

A compreensão dos movimentos de matéria e energia através da estrutura espacial constitui peça chave para o entendimento dos impactos que as alterações promovidas no arranjo de um ou vários elementos da paisagem causa no arranjo global da paisagem trabalhada.

$7 \quad$ "este sistema vivo apresenta três grandes características: estrutura, funcionamento e mudança. Estrutura da paisagem é o padrão espacial ou um arranjo de elementos paisagísticos. Funcionamento é o movimento e os fluxos de animais, plantas, água, vento, materiais e energia através da estrutura. E a mudança é a dinâmica ou alteração no padrão espacial e de funcionamento ao longo do tempo." Tradução livre do autor. 

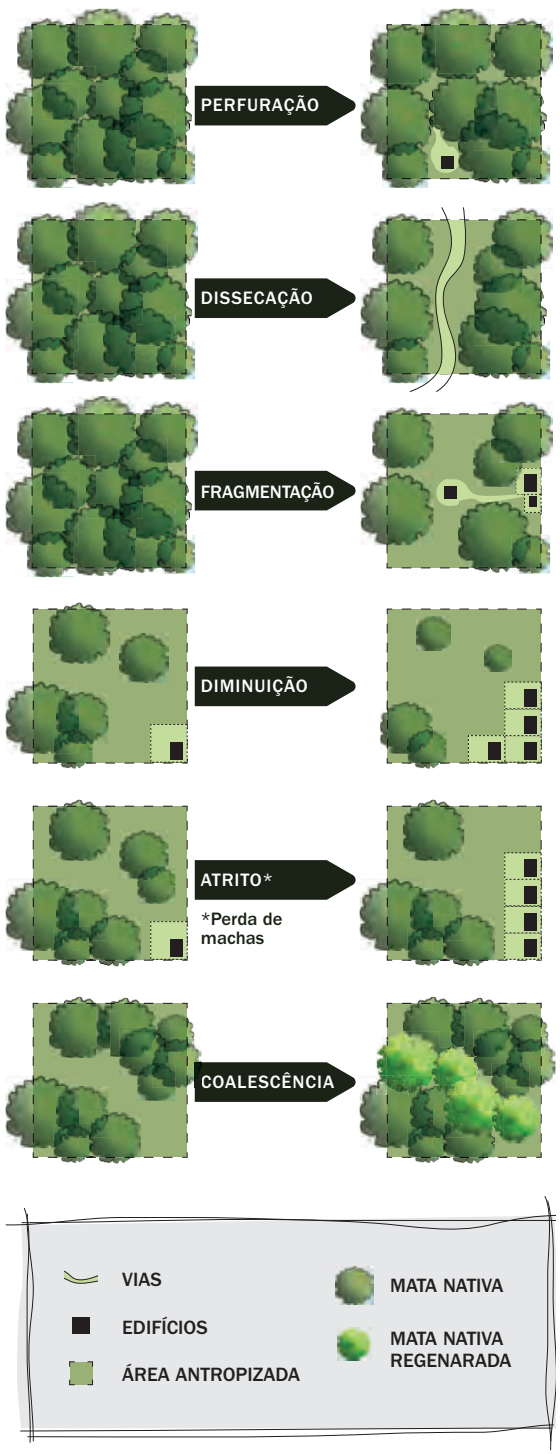

Desenho 02 | Processos espaciais resultantes de processos naturais e atividades humanas. Adaptado de: Silvio Macedo In: PELLEGRINO, PR.M. Pode-se planejar a Paisagem? Revista Paisagem e Ambiente:ensaios. n13. São Paulo: FAU, 2000.
Pra tanto, a organização espacial do território é compreendida, na Ecologia da Paisagem, por 3 elementos fundamentais: manchas, corredores e matrizes. Aplicáveis em qualquer situação de análise, esses três elementos são de fundamental importância para o planejamento da paisagem visto que o seu arranjo condiciona os movimentos e mudanças. (DRAMSTAD, OLSON, \& FORMAN, 1996)

Toda a diversidade na distribuição dos elementos da paisagem são frutos de uma heterogeneidade do substrato, modificados pelas ações naturais e pela atividade humana. As manifestações dessas alterações são visíveis ao longo do tempo por processos como fragmentação, perfuração, dissecação, diminuição, atrito e coalescência. (PELLEGRINO P. R., 2000; DRAMSTAD, OLSON, \& FORMAN, 1996)

Tão importante como a constatação do fenômeno, para a ecologia da paisagem importa compreender a forma, dimensão e disposição dos elementos, visto que a disposição espacial dos corredores, manchas e matrizes condicionam as relações estabelecidas entre elas, além dos processos que se estabelecem em suas fronteiras e nos hiatos espaciais criados.

A compreensão dos impactos causados por cada uma das alterações permite o melhor controle do rearranjo dos elementos que compõem a paisagem, contribuindo para o planejamento sustentável do território com vistas a se reduzir os processos de fragmentação e degradação de seus elementos, através de mecanismos de promoção da concentração, conexão e conservação dos recursos naturais existentes, assegurando certa estabilidade ao uso do território em longo prazo. 
1.1

A ecologia da paisagem e planejamento

Atualmente os assentamentos humanos enfrentam cada vez mais a necessidade de atenuar e se adaptar aos efeitos das mudanças climáticas, estabelecendo maior eficiência energética reduzindo a emissão de $\mathrm{CO}^{2}$ na atmosfera, aperfeiçoando os sistemas de mobilidade e criando mecanismos de resiliência contra o aumento das temperaturas, secas, inundações e elevação dos níveis dos oceanos. Estas demandas têm levado a uma busca por novos modelos integrados em que planejamento e questões de design se sobrepõem, diluindo suas fronteiras disciplinares tal é o contexto no qual a ecologia da paisagem vem ganhando destaque.

No que tange o planejamento do território as soluções são investigadas abrangendo as mais diversas escalas, seja do macro (como por exemplo, criação de reservas, parques, corredores ecológicos e planícies de alagamento) ao micro (por exemplo, na definição de pavimentações de passeios, desenho e ruas e praças). Nessa ultima abordagem os edifícios integram também características da Ecologia da Paisagem pela incorporação de paredes e telhados com vegetação, como parte de um mecanismo de conservação da energia, sequestro de carbono, moderação de microclimas e absorção das águas pluviais.

Segundo Cecília Herzog:

"Para um planejamento sustentável é preciso identificar os elementos estratégicos da paisagem, de ordem ecológica e social. É importante avaliar a integridade da paisagem, o que inclui a integridade ecológica - a saúde da fauna e da flora, e também as funções sociais - relativas a questões econômicas, recreativas e aos recursos estéticos. Os benefícios e locais devem ser acessiveis a todos, deve proporcionar melhoria na interação social." (HERZOG, 2009) 


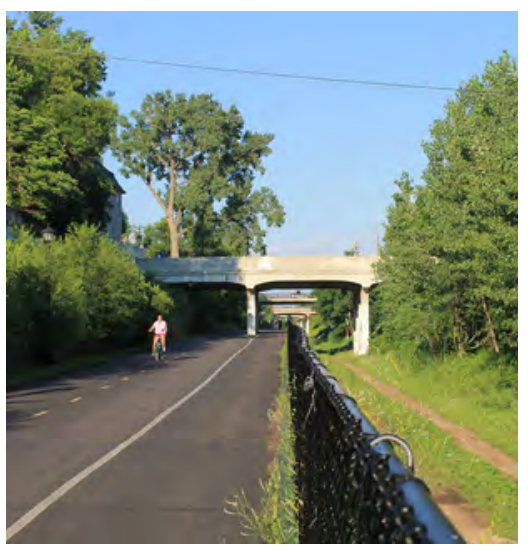

Foto 08 | Midtown Greenway em Minneapolis Rota cicloviária e de pedestres arborizada e livre de interferências rodoviárias conecta região dos lagos aos subúrbios a oeste, aproveitando-se da antiga linha ferroviária de $8 \mathrm{~km}$ de extensão.

Autor: Gerson Amaral - 2014.
Na prática do planejamento contemporâneo, os projetos de espaços abertos em todas as suas variações como praças, parques, espaços recreativos e reservas ecológicas são tratados de forma isolada ou apenas como tópicos de planos em macro escalas, reduzindo consideravelmente os benefícios potenciais resultantes de uma possível integração dos mesmos. É desconhecido o caráter sistêmico dos espaços livres, tal como define Queiroga (2012), pois se ignora o fato de que:

\footnotetext{
"direta ou indiretamente, todos os espaços livres de um determinado recorte espacial - subespaço - estabelecem relações entre si, na medida em que se constituem enquanto uma totalidade integrante do sistema de objetos e do sistema de ações do referido subespaço (da escala de vizinhança à escala regional, ou mesmo de escalas territoriais mais amplas)." (QUEIROGA, 2012, p. 74)
}

Nas últimas décadas, contudo, já é possível observar o surgimento de diversas intervenções urbanas em algumas cidades do mundo que têm como objetivo a promoção de criação de sistemas urbanos integrados com os sistemas naturais que the permeiam, trazendo benefícios tanto de ordem social, econômica e ecológica. Oportunidades urbanas como espaços lineares ao longo de cursos d'agua e linhas ferroviárias abandonadas potencialmente provedoras de valores ecológico, econômico, cultural ou histórico têm recebido cada vez mais destaque nas últimas décadas. Esses espaços têm sido repropostos como "Infraestruturas Verdes" que enfatizam os benefícios ambientais, econômicos e sociais prestados por uma rede de espaços físicos.

Complementar ao sistema de infraestruturas tradicionais, as Infraestruturas Cinzas, as Infraestruturas Verdes (IEV) assim são definidas pelo Conservation Fund: 


\begin{abstract}
"Green infrastructure is our nation's natural life support system - an interconnected network of waterways, wetlands, woodlands, wildlife habitats, and other natural areas; greenways, parks and other conservation lands; working farms, ranches and forest; and wilderness and other open spaces that support native species, maintain natural ecological processes, sustain air and water resources and contribute to the health and quality of life for America's communities and people" ${ }^{8}$. (BENEDICT \& McMAHON, 2006)
\end{abstract}

Como se vê, as Infraestruturas Verdes podem ser entendidas sob uma ótica ampla, abrangendo qualquer estratégia de intervenção sobre o espaço físico que promova a criação ou preservação de suportes físicos adequados aos processos ecológicos que garantam a qualidade dos meios bióticos e abióticos, com impactos diretos sobre a qualidade de vida da população atual e futura.

Os princípios básicos da Ecologia da Paisagem são incorporados ao conceito de Infraestruturas Verdes, com foco na ideia da conectividade e a necessidade de compreensão de todo o contexto físico, biológico e social que envolve a área trabaIhada, seja de estudo ou de projeto. Aplicando tais conceitos em planejamento e projeto, as Infraestruturas Verdes trabalha para a produção de um sistema interconectado de espaços livres e áreas naturais a serem manejadas e protegidas de forma a prover benefícios ecológicos para o meio ambiente e, consequentemente para o homem. O termo Infraestruturas Verdes vem a ser adotado como forma de enfatizar as áreas

8 "Infraestrutura verde é o sistema de suporte natural a vida da nossa nação - uma rede interligada de cursos de água, planícies de alagamento, florestas, habitats selvagens, e outras áreas naturais; corredores verdes, parques e outras áreas de conservação; fazendas, ranchos e florestas; e outros espaços abertos e selvagens que dão suporte a espécies nativas , na manutenção dos processos ecológicos naturais , conservação dos recursos de ar e água e que contribuem para a saúde e qualidade de vida para as comunidades e os povos da América” Tradução livre do autor. 
verdes como algo necessário para o suporte da vida natural, além da desconstrução da ideia de áreas verdes como autossustentáveis, visto que implicam também práticas de manutenção (BENEDICT \& McMAHON, 2006).

Disciplinas como Biologia, Ecologia da Paisagem, Planejamento urbano e Regional, Arquitetura da Paisagem, Geografia, Engenharia Civil trazem relevantes contribuições, através de seus princípios e técnicas, para o sucesso da aplicação das novas ideias em qualquer que seja o ambiente ou escala.

As Infraestruturas Verdes se mostram, cada vez mais, como ferramenta fundamental para o desenvolvimento de planos urbanísticos e paisagísticos, visto que propõe a ocupação do solo dentro das potencialidades e limitações da paisagem, com vistas ao menor impacto possível, ou até a mitigação de danos ambientais na promoção de uma nova configuração da matriz espacial. 

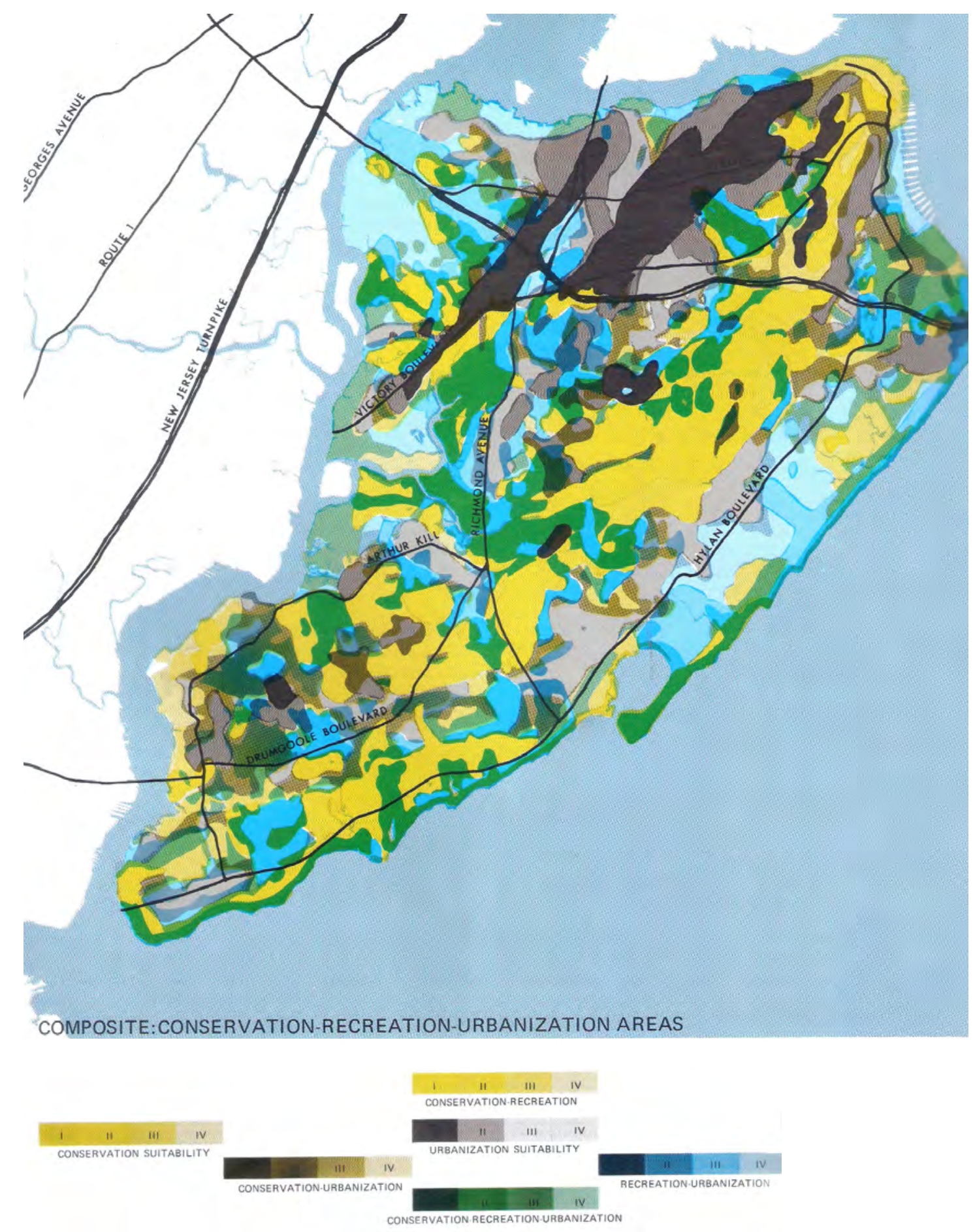

Mapa 01 | Mapas temáticos desenvolvidos por McHarg para análise das potencialidades do território. Fonte: McHarg, lan L. Design with nature. John Wiley \& Sons, 1992. 
Sho

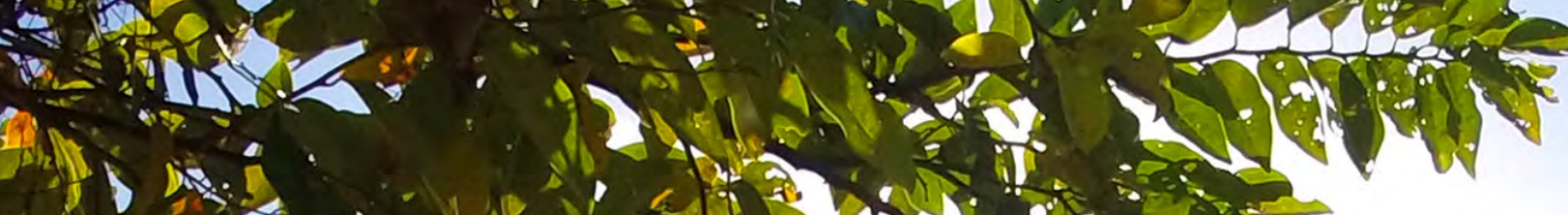

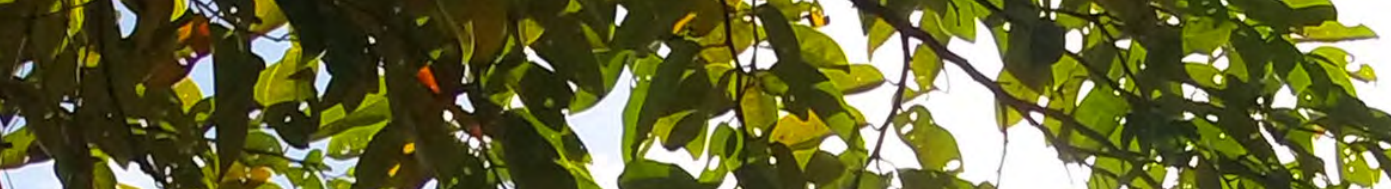

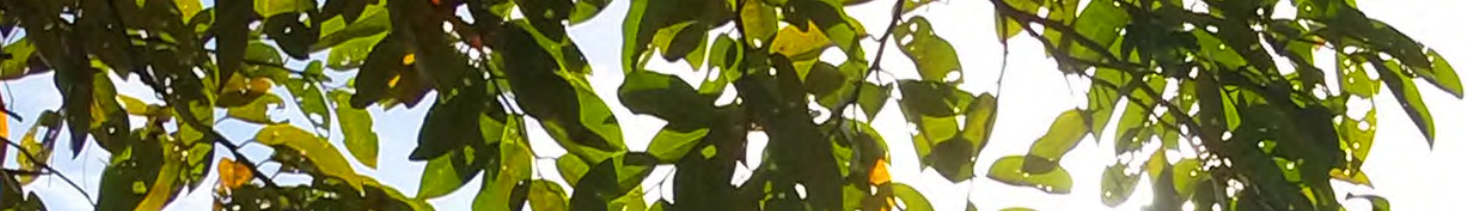

$72,1,10=1$

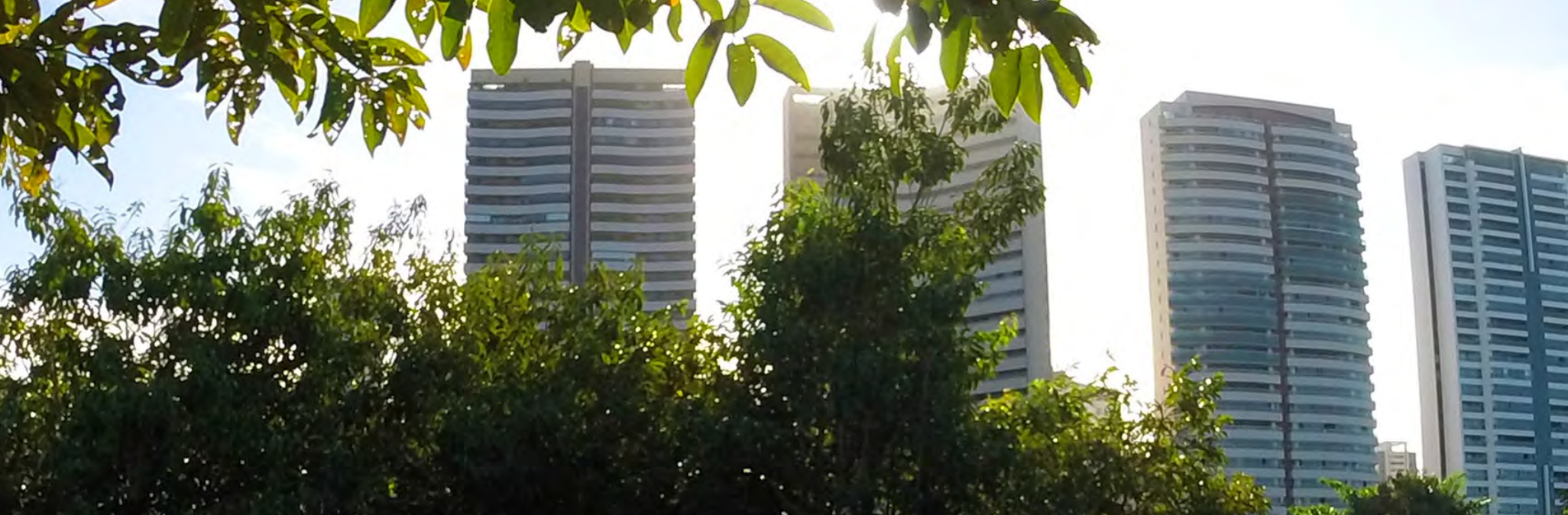
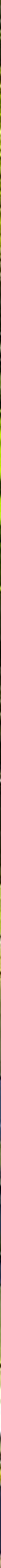


\section{CAPÍTULO II}

\section{As infraestruturas verdes no contexto das águas urbanas}

Dentro do vasto espectro de elementos trabalhos no planejamento da paisagem, a questão da água, sua disponibilidade e qualidade, constitui peça chave em quase todas as abordagens possíveis, pois é um elemento que impacta diretamente nas condições de solo, microclima, vegetação, fauna, provimento de alimentos e saneamento básico, entre outros fatores.

O tratamento dos nossos recursos hídricos, considerando todo o ciclo hidrológico, constitui um dos principais focos de intervenção trabalhados pelas Infraestruturas Verdes, a qual toma como unidade de planejamento a bacia hidrográfica, visto que ela contempla todas as etapas do ciclo que de alguma forma podem sofrer interferências do ser humano. Além disso, o planejamento integrado da bacia hidrográfica potencializa a capacidade de aproveitamento dos mais diversos benefícios disponíveis pelos rios.

A importância de uma bacia hidrográfica fica evidente quando percebemos sua capacidade de estruturação na ocupação de um território pela oferta de uma hidrovia natural de transporte de mercadorias e pessoas. Foi ao longo de uma bacia hidrográfica que vimos surgir, por exemplo, uma rede de assentamentos urbanos ao longo do rio Parnaíba, que durante muitos anos estruturou a economia do estado do Piauí. Na mesma lógica se estruturam cidades no Ceará, na bacia do Acaraú e na bacia do rio Jaguaribe, definindo a estruturação do território do estado. 
Na Amazônia, ainda vemos, até os dias atuais, o predomínio dos rios como eixos fundamentais de comunicação e transporte.

Ao compor um sistema integrado natural determinado pelo ciclo das águas, a bacia hidrográfica passou a adquirir importância como unidade de planejamento, tal como já havia sido demonstrado pela Tennessee Valley Authority (TVA) ao considerar a bacia hidrográfica para promover o controle das enchentes, a produção de energia e o desenvolvimento do comércio e da navegação fluviais, ainda nas primeiras décadas do século XX. (PELLEGRINO P. R., 2000)

As linhas de drenagem, condicionadas fortemente pelo relevo e solo, dentro da visão ecológica da paisagem, constituem um dos maiores potenciais de produção de conectividade ecológica entre fragmentos de habitats, tendo em vista que "quase todos os recursos naturais e atividades humanas em uma paisagem dependem dos rios e sistema de drenagem das águas superficiais existentes". (PELLEGRINO P. R., 2000) A qualidade da conectividade hidrológica depende de fatores como a gravidade, a topografia, a vegetação, a geologia e as interferências humanas ao longo de seu curso.

Conectividade é a possibilidade de espécies e populações circularem entre os diversos fragmentos que compõem o mosaico da paisagem, dispersando as populações e promovendo a interação genética entre os diversos grupos antes isolados. O tempo e as características desse movimento dependem de cada espécie e são condicionadas pelas características físicas dos corredores. Estes podem ser criados tanto em áreas rurais como urbanas, basta que promovam a permeabilidade da flora e fauna, uma conexão funcional para as diversas espécies (METZGER, 2001). Em termos ecológicos, a conectividade resulta na formação de corredores ecológicos ao longo dos cursos dos rios através da preservação das matas ciliares. Essas matas são eficazes para a contenção da degradação e fragmentação de manchas de vegetação, permitindo a transito de espécies dentro da matriz territorial. 
Conforme Pellegrino:

\begin{abstract}
"Um corredor ao longo de um rio é a faixa de vegetação que acompanha a superfície de água corrente. O corredor pode apenas incluir esta superfície de água e suas margens adjacentes, ou pode ser largo o suficiente para incluir a planície aluvial, suas encostas e faixas de terras altas limítrofes. Vegetação ciliar, geralmente refere-se à vegetação da planície aluvial ou da área de inundação direta de um rio." (PELLEGRINO P. R., 2000)
\end{abstract}

São evidentes os benefícios ambientais das matas ciliares, tendo em vista que a vegetação preservada constitui filtros naturais que garantem a qualidade das águas, retendo sedimentos e nutrientes ao longo de todo o curso hídrico. Adicionalmente, a vegetação e suas raízes possuem importante papel de estabilização do solo, redução da velocidade de escoamento e consequentemente proteção das margens e dos processos erosivos incidentes na bacia. A vegetação também contribui para a interceptação das águas das chuvas através da folhagem em geral, reduzindo impacto de queda sobre o solo e aumentando a sua capacidade de infiltração. A matéria orgânica produzida pela mata se acumula sobre o solo ajudando na minimização da evaporação, prolongando a umidade no solo e aumentando a sua fertilidade natural, pela diversificação do conjunto de microrganismos que o compõe e que ajudam no processamento dos componentes orgânicos e fixação de macro e micronutrientes.

O Código Florestal Brasileiro ${ }^{5}$, em sua definição de Áreas de Preservação Permanente, além da previsão de reservas legais, prevê a preservação da mata nativa em locais frágeis como

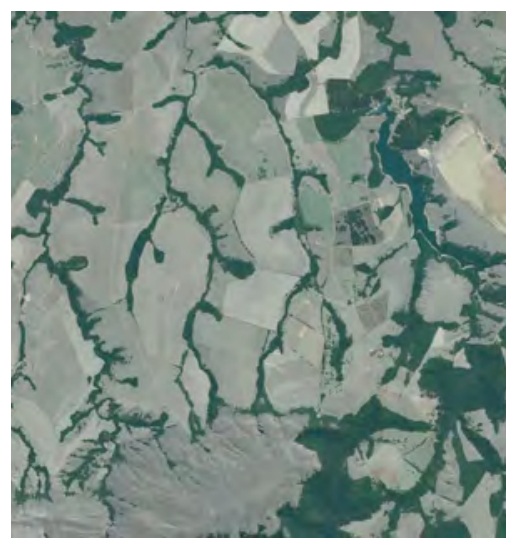

Foto 10 | Aplicação do Código Florestal visa a conservacão da mata ciliar dos rios brasileiros. O padrão espacial resultante preserva as linhas de drenagem criando corredores ecológicos que conectam os fragmentos de mata ao longo do território. Imagem da zona rural do município de Araxá-MG. Fonte: Google Earth, acesso em 14/02/2016. 

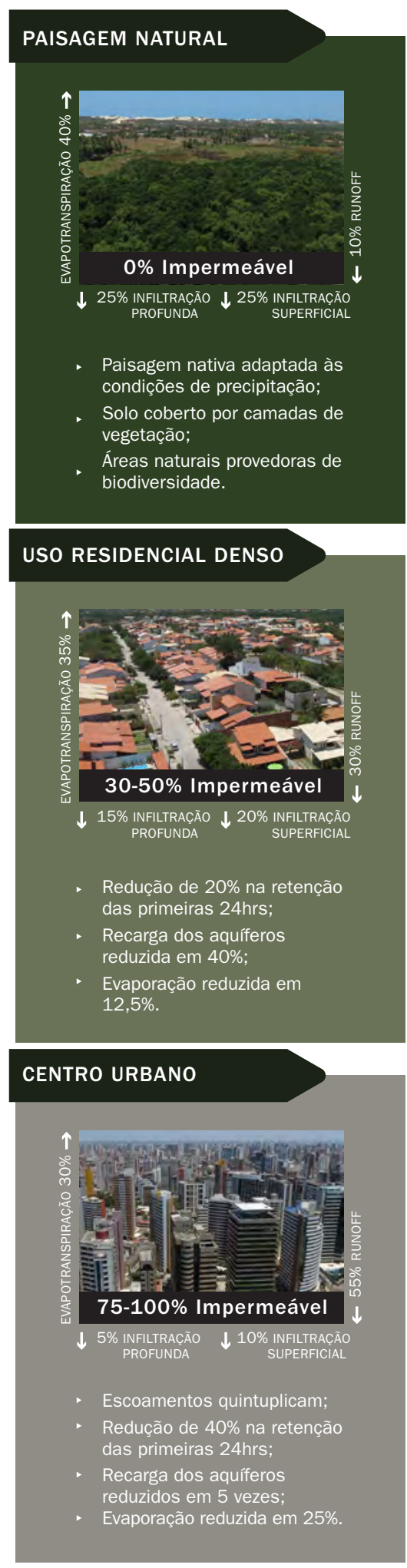

Gráfico 01 | Impactos da urbanização consequente impermeabilização do solo nas taxas de infiltração e escoamento superficial. Adaptado de WATSON \& ADAMS (2011). Autor: Gerson Amaral. beiras de rios, topos de morros e encostas, que não podem ser desmatados para não causar erosões e deslizamentos, além de proteger nascentes, fauna, flora e biodiversidade, entre outros. Determinando larguras mínimas das margens a serem preservadas em relação com a largura do rio, o código brasileiro tenta normatizar minimamente a preservação de corredores verdes ao longo de todas as bacias hidrográficas no país.

A manutenção da vegetação contribui significativamente para a manutenção do ciclo hidrológico. Em uma área preservada, a taxa de escoamento superficial é reduzida, as taxas de infiltração são altas e a evaporação é regulada pela vegetação existente, criando um microclima mais estável.

A supressão da vegetação altera significativamente o ciclo, retirando a proteção do solo e aumentando as taxas de evaporação pelo aumento da incidência solar e redução da umidade do ar. Os impactos são ainda maiores nas áreas urbanizadas, onde a impermeabilização do solo tem impacto direto na capacidade de infiltração, aumentando as taxas de escoamento superficial e diminuindo o lençol freático. Esse processo de redução da taxa de infiltração altera significativamente a dinâmica da bacia hidrográfica, tal como afirma Gorski:

\footnotetext{
"Quando a capilaridade de uma bacia hidrográfica se reduz, dá-se o encurtamento do ciclo hidrológico, em que a proporção de infiltração é bem menor que a de evaporação, ocasionando a contribuição concentrada de deflúvios e propiciando a incidência de inundações." (GORSKI, 2010)
}

Além dos já citados prejuízos ecológicos, o impacto da alteração do ciclo hidrológico nas bacias hidrográficas brasileiras, associado a uma urbanização caótica e a um uso inadequado do solo, tem tornado as inundações um dos maiores problemas urbanísticos a serem enfrentados. 0 aumento da densidade construtiva e a pressão imobiliária tem forçado a ocupação das margens de inundação e até dos próprios leitos, eliminando as áreas naturais de armazenamento nos momentos de pico de vazão, os leitos maiores dos rios. 


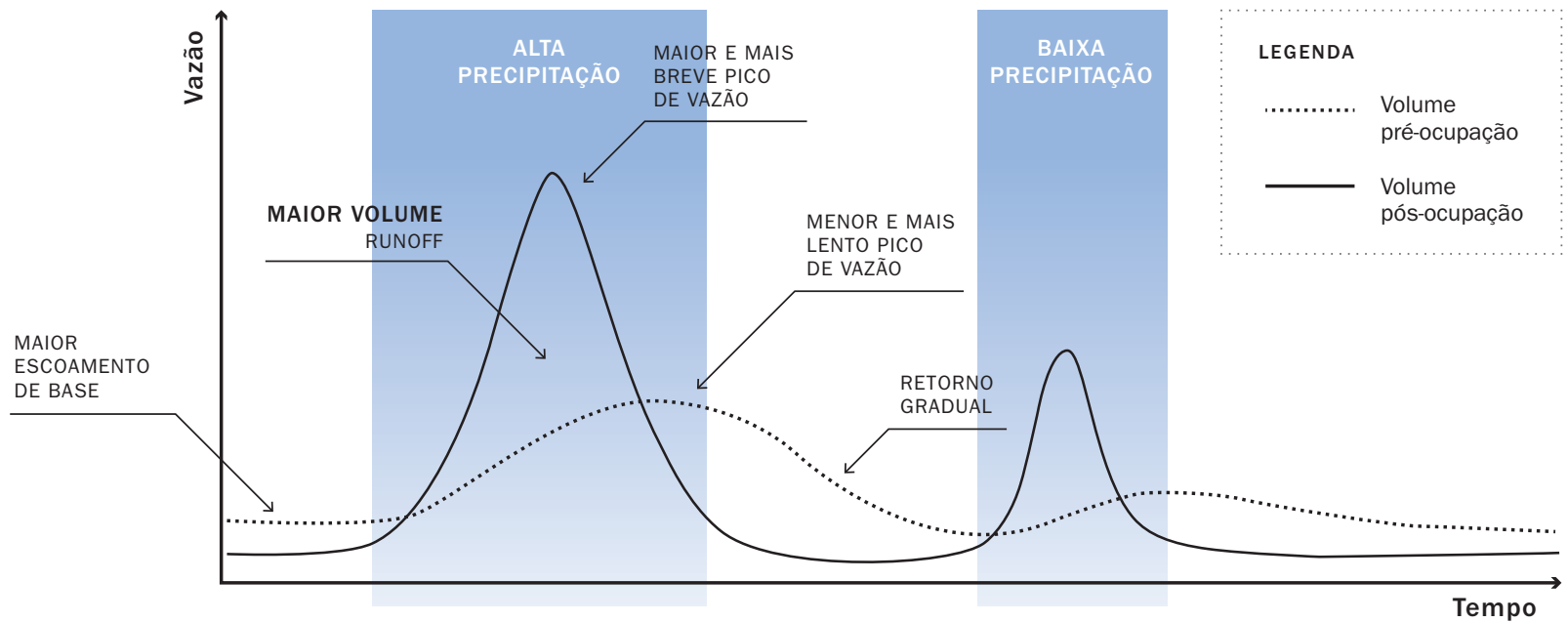

Conforme afirma Canholi na busca de soluções de drenagem urbana:
Gráfico 02 | Comportamento do caudal de um curso hídrico antes e após ocupação e impermeabilização de sua bacia de contribuição. Adaptado de EPA, 2005. Autor: Gerson Amaral.

Por mais que as soluções tradicionais resultem apenas na transferência e concentração do problema de vazão para outro ponto da bacia hidrográfica, essa ainda é a postura adotada pelos planos de drenagem da maior parte das cidades brasileiras. Uma solução que acaba por sobrecarregar ainda mais os rios e córregos que ainda possuem alguma capacidade de absorção ou chegam a afetar diretamente as populações moradoras nas áreas mais baixas da cidade. 

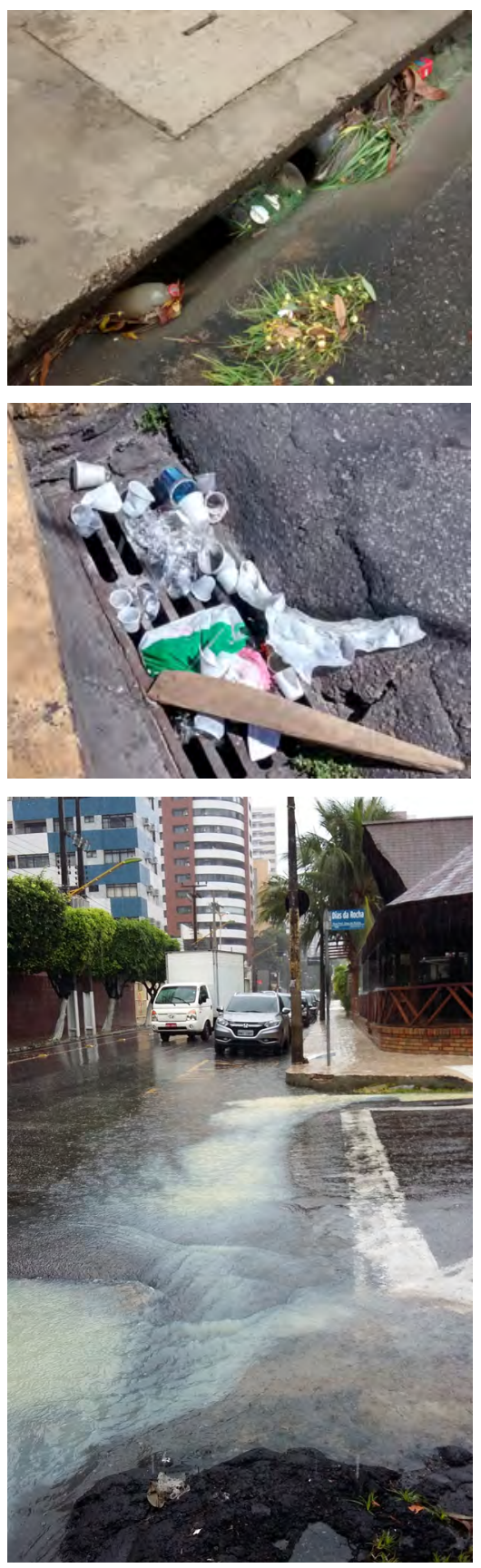

Fotos 11, 12 e 13 | Exemplos típicos do carreamento de lixo doméstico e sedimentos durante os eventos de precipitação. Quando não prejudicam a vazão do sistema de drenagem, comprometem a qualidade das águas de córregos, rios e praias. Local: Fortaleza-CE. Autor: Gerson Amaral - 2015.
Os efeitos da urbanização sobre o volume do pico de vazão de um curso hídrico são mais impactantes nas microbacias tal como exemplifica Righetto:

\footnotetext{
"em uma bacia urbana de $1 \mathrm{~km}^{2}$, com coeficiente de Runoff médio igual a 0,10, ocorrendo novas impermeabilizações em 30\% da área de drenagem, o deflúvio superficial passa a ser 3,55 vezes maior, o que pode resultar em sérios problemas de alagamentos e inundações em pontos críticos da bacia de drenagem." (RIGHETTO, 2009)
}

Além dos problemas relacionados ao aumento do volume de escoamento direto durante os eventos de precipitação, a urbanização também promove uma alteração dos componentes presentes na água, dependendo da localização geográfica, condições meteorológicas, presença ou não de vegetação e presença de cargas poluidoras. 0 aumento do coeficiente de runoff confere um maior poder de transporte ao escoamento das águas pluviais que, quando escoa pela superfície de captação, carrega consigo poluentes sólidos ou solúveis que são concentrados nas linhas de drenagem. As fontes dessa poluição são das mais diversas, desde sedimentos de canteiros de obras, lixo doméstico, resíduos industriais, resto de plantas, fezes de animais, óleos, graxas, etc.

Gerada pelo escoamento superficial principalmente em zonas urbanas com grandes extensões impermeáveis, esse tipo de poluição, que não possui uma fonte poluidora específica, mas origina-se em toda a área de captação da bacia hidrográfica, é chamada de poluição difusa. (NOVOTNY, 2003) Sua contribuição para o aumento da carga poluidora nos cursos hídricos tem se mostrado expressiva, conforme afirma MOURA (2013):

\footnotetext{
"estudos recentes indicam que os escoamentos pluviais apresentam maior carga de demanda bioquímica de oxigênio (DBO), chumbo e cobre do que os efluentes de estações de tratamento secundário de esgoto, além das altas taxas de coliformes (milhares a milhões/100ml), óleos e graxas, além das maiores concentrações de micropoluentes tóxicos."
} 
Fica claro que a poluição dos rios urbanos brasileiros não é culpa exclusiva do lançamento direto de esgoto doméstico ou industrial. 0 tratamento desses efluentes antes do lançamento na rede hídrica certamente trará grandes melhorias para a qualidade geral da água, contudo não será uma solução definitiva para a total recuperação da bacia hidrográfica visto que a poluição difusa ainda será uma grande fonte de carga poluidora.

A drenagem urbana, ao contrário de outras utilidades públicas como água, esgoto, eletricidade, gás, etc., é intrinsecamente ligada ao processo de urbanização. É sua consequência direta. Não pode ser dissociada e não é um problema somente hidráulico, como normalmente é tratada, mas sim um problema urbano que demanda uma visão ampla sobre o processo de urbanização do qual faz parte integrante. (CANHOLI, 2005) A qualidade dessa urbanização terá impacto direto sobre os impactos no solo, na biodiversidade, no microclima e principalmente na qualidade das águas pluviais de sua bacia de contribuição. Segundo Tereza Herling, a adoção da bacia hidrográfica como unidade de planejamento e gestão dos recursos hídricos, presente no novo arcabouço legislativo e institucional e nas propostas técnicas delineadas ao longo dos anos 90 em São Paulo, aponta para a recuperação da visão sistêmica na exploração dos recursos naturais pela cidade. (HERLING, 2002) Apesar desses avanços, essa postura ainda é fato pontual na política de planejamento das cidades brasileiras.
Foto 14 | Mancha negra evidencia a alta concentração de poluentes carreadas pelo riacho Maceió (Fortaleza/CE). Fenômeno é recorrente logo após as primeiras chuvas da quadra invernosa. Registro feiro em 13/02/2014. Fonte: < http://cnews.com. $\mathrm{br} /$ content/images/sites/cnews/mucuripe manchaaaa.jpg>. Acesso em 12/01/2016.

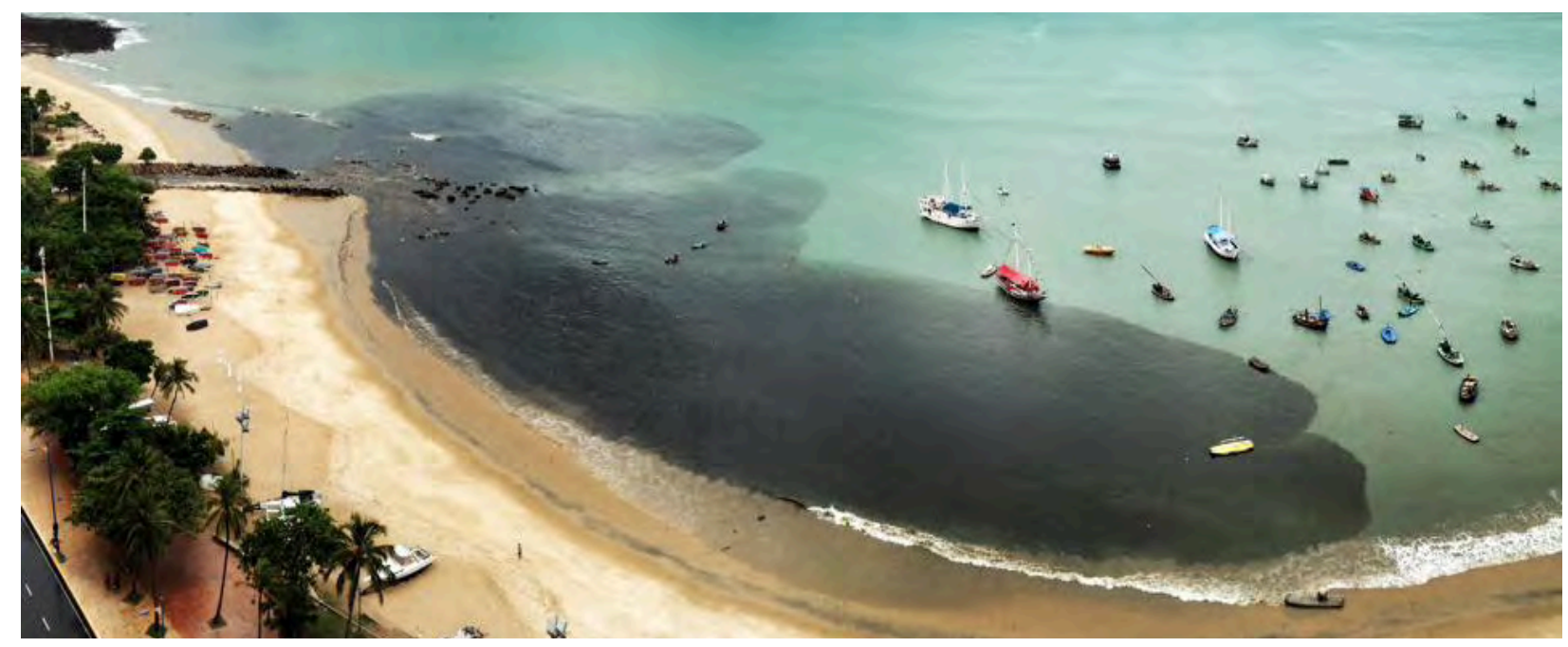




\section{1}

Infraestruturas verdes na escala do manejo das águas

O combate à poluição difusa tem sido um dos focos do planejamento ecossistêmico da paisagem. Nessa perspectiva, enquanto ação projetual, as áreas livres públicas passam ser incorporadas a estratégias de intervenções paisagísticas que, para além de um mero embelezamento urbano, passam a desempenhar funções infraestruturais relacionadas ao manejo das águas urbanas, conforto ambiental, biodiversidade, alternativas de circulação, acessibilidade e imagem local. (PELLEGRINO, 2008). Conforme destaca Queiroga, "a contribuição ambiental dos espaços permeáveis e vegetados de uma cidade, por exemplo, se constitui importante serviço ambiental urbano, mesmo que não estejam conectados fisicamente". (QUEIROGA, 2012)

Na rede de espaços verdes no interior da malha urbana, integrada com o sistema de drenagem, estaria a chave para a solução da qualidade das águas urbanas, promovendo o controle de poluição das águas pluviais ainda na fonte.

Uma abordagem das Infraestruturas Verdes mais focada nas questões referentes à qualidade das águas tem origem, nos EUA, como uma evolução para uma resposta mais clara às exigências do Clean Water Act $^{6}$ e leis reguladoras relacionadas considerando os impactos do escoamento de águas pluviais urbanas para a qualidade da água dos recursos hídricos.

De acordo com a Environmental Protection Agency (EPA) dos EUA, Infraestruturas verdes são assim definidas:

"systems and practices that use or mimic natural processes to infiltrate, evapotranspirate (the return of water to the atmosphere either through 
evaporation or by plants), or reuse stormwater or runoff on the site where it is generated. Green infrastructure can be used at a wide range of landscape scales in place of, or in addition to, more traditional stormwater control elements to support the principles of LID" (Environmental Protection Agency, 2015) ${ }^{7}$

Essa visão contrasta com o conceito de Infraestruturas Verdes adotado pelo Florida Greenways Commission and Conservation Fund, o qual enfatiza amplas unidades paisagísticas como parques, áreas naturais, corredores verdes, zonas agropastoris em uma escala maior de trabalho, muito condicionada às demandas próprias da geografia do estado. A EPA, por sua vez, trabalha em uma menor escala, mais próprios para os contextos urbanos, tomando uso de soluções como telhados verdes, arborização, jardins de chuva, valas de infiltração, alagados construídos, canteiros pluviais, entre outras como componentes das Infraestruturas Verdes, os quais serão apresentados mais a frente.

Seguindo um enfoque similar ao da EPA, um movimento de criação de paisagens urbanas, que se utiliza dos conceitos das infraestruturas verdes para mimetizar, no ambiente antropizado, funções ecológicas e hidrológicas dos ambientes naturais, é percebido na região noroeste Pacífico, nos estados de Washington e Oregon, nos Estados Unidos, e na Província da Colúmbia Britânica, no Canadá. Tomando o manejo das águas como principal elemento estruturador das soluções adotadas.

Na escala do estudo pretendido, o termo "Infraestruturas Verdes (IEV)" é empregado para se referir a práticas de manejo de águas pluviais que imitam processos ecológicos naturais em oposição as soluções tradicionais de engenharia, as ditas infraestruturas cinzas. Essa rede infraestrutural implanta-se integrada a quase todas as paisagens urbanas, incrementan-

7 "sistemas e práticas que utilizam ou imitam os processos naturais de infiltração, evapotranspiração (o retorno da água para a atmosfera , quer por evaporação ou por plantas), reutilização de águas pluviais ou de escoamento no local onde ele é gerado. Infraestrutura verde pode ser usada em uma ampla gama de escalas de paisagem substituindo, ou complementando, os tradicionais elementos de controle de águas pluviais para apoiar os princípios do LID." 
do a qualidade ambiental de áreas já urbanizadas, seja através de intervenções em parques urbanos, praças, linhas de drenagem, calçadas, jardins condominiais e residenciais ou até na arquitetura pela incorporação de tetos verdes, paredes vegetadas, cisternas de coleta de água pluvial entre outras soluções que, integradas, promovem a retenção das águas pluviais, reduzindo os efeitos das enxurradas, retendo a poluição difusa e promovendo a infiltração no solo, contribuindo para a recarga das águas subterrâneas.

Arquitetos paisagistas estão especificamente qualificados para projetar essas Infraestruturas Verdes, de forma a integrá-la aos edifícios, demais elementos construídos e redes de infraestrutura urbana, e, desse modo, aumentar a relevância social e ambiental dos projetos de arquitetura paisagística em nossas cidades.

A IEV propõe a adoção de novas tecnologias de cunho mais sustentável que buscam associar as ações de controle de vazão à qualidade do desenho urbano propondo uma nova relação do cidadão com o espaço urbano que habita, assim como uma nova relação com os recursos hídricos que permeiam o bairro. 0 projeto de manejo das águas se baseia no conceito de Desenvolvimento de Baixo Impacto (Low Impact Development - LID) - uma abordagem ecológica de gestão das águas pluviais na fonte.

O conceito busca diluir as soluções de controle de cheias ao longo de todo o curso hídrico e não apenas em pontos específicos, o que faz com que seja uma abordagem sistemática de intervenção que deve considerar para o tratamento todo o rio, desde sua nascente até sua foz em diversas escalas. Para tanto um dos objetivos do projeto consiste no aumento das áreas permeáveis dentro da malha urbana permitindo a recarga de aquíferos e a diminuição do escoamento superficial, ao mesmo tempo em que ajuda a estabilizar a vazão dos riachos.

A proposta fundamenta-se na retenção das águas superficiais, através do uso de tipologias de projetos paisagísticos de alto desempenho. Dentre as diversas soluções desenvolvidas, podemos identificar as seguintes definições de tipologias IEV: 


\section{1 .1}

\section{Jardim de Chuva}

Trata-se de uma solução de controle de runoff, promoção de infiltração e retenção de poluentes, especialmente aqueles carreados no início de cada precipitação (first flush). Basicamente consistem em uma depressão topográfica que recebe a contribuição pluviométrica de áreas impermeabilizadas do terreno (vias, passeios e cobertas das edificações).

Seu solo é tratado de forma a aumentar a capacidade de absorção de água, ao mesmo tempo que promove a filtragem de poluentes que são processados biologicamente pelo conjunto de microorganismos presentes no solo e nas raízes da vegetação implantada. Segundo Moura (2013), o emprego de vegetação arbustiva contribui significativamente para o aumento da eficiência na retenção de poluentes, além de trazer melhores benefícios estéticos e menor manutenção do sistema.

Por medida de segurança um extravasor locado na cota de transbordamento visa assegurar a drenagem nos casos de um volume de água superior a capacidade de retenção do jardim.

Os jardins de chuva podem ser adaptados às diversas condições espaciais podendo acontecer com versões mais compactas no caso da pouca disponibilidade de espaços livres. Algumas versões, inclusive, dispensam a infiltração e contam como a evaporação, evapotranspiração e transbordamento, adaptando-se facilmente a qualquer edificação ou espaço urbano mesmo que densamente ocupado.
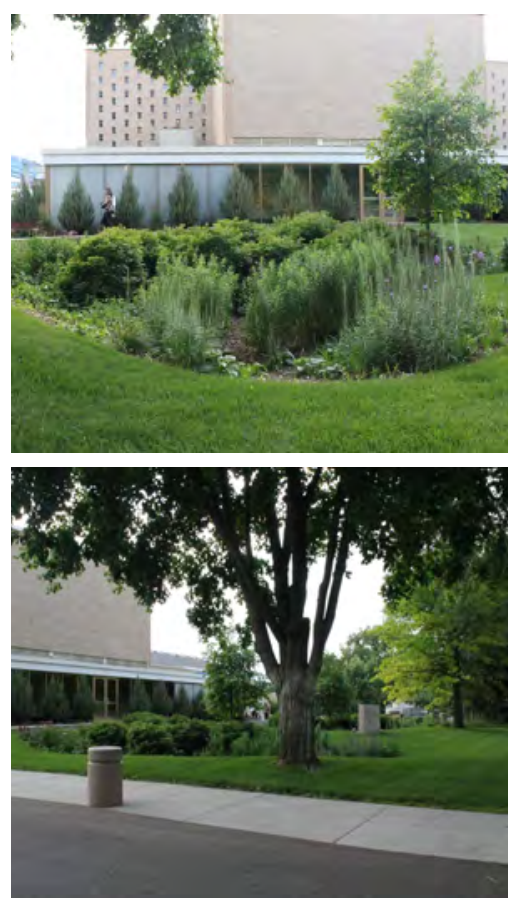

Fotos 15 e 16 | Exemplo de jardim de chuva formado por uma depressão topográfica. O uso de vegetação arbustiva contribui para o aumento da eficiência do sistema. Local: St. Mary's Greek Orthodox Church, Minneapolis, EUA. Autor: Gerson Amaral - 2014. 


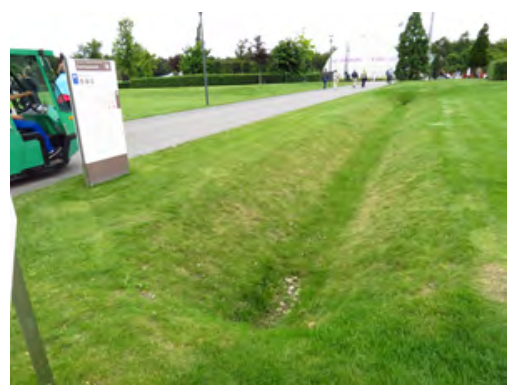

Foto 17 | Exemplo de biovaleta tratada apenas com tapete de grama. Local: Floriade, Venlo, Holanda. Autor: Gerson Amaral - 2012

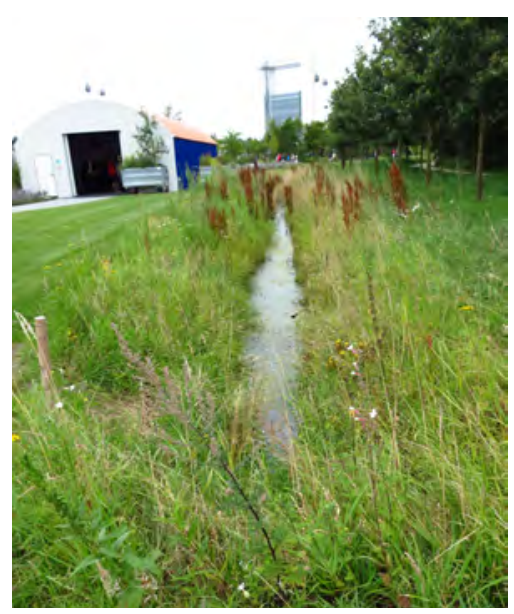

Foto 18 | Exemplo de biovaleta tratada com gramíneas diversas de tamanhos variados. Local: Floriade, Venlo, Holanda. Autor: Gerson Amaral - 2012

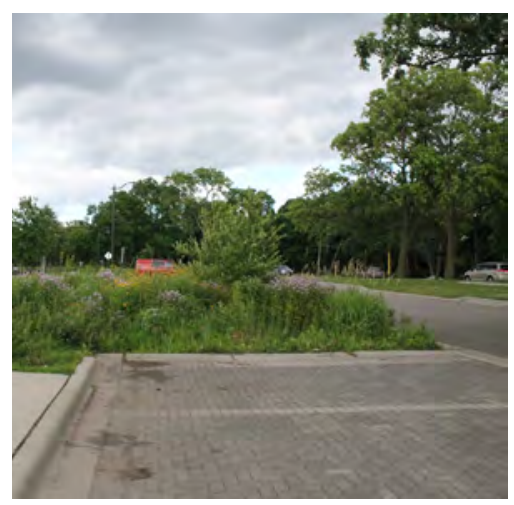

Foto 19 | Exemplo de biovaleta tratada com vegetação arbustiva cuja função é captar e conduzir as águas pluviais de um estacionamento e via de acesso. Local: Calhoun Parkway, Minneapolis, EUA. Autor: Gerson Amaral - 2014.

\subsection{2}

\section{Biovaleta ou Valas de Infiltração Vegetadas}

A biovaleta constitui uma variação do jardim de chuva diferenciando deste por constituir um elemento de condução superficial das águas pluviais ao mesmo tempo que promove a infiltração e a retenção de poluentes através da fitorremediação. As biovaletas podem ter sua superfície coberta apenas por grama ou receber vegetação arbustiva. Assim como no jardim de chuva, na biovaleta com vegetação arbustiva o desempenho na redução da velocidade de escoamento e a eficiência na filtragem das águas pluviais são maiores.

Dependendo da declividade do sítio onde se implanta, adaptações devem ser realizadas para que a velocidade do escoamento superficial não promova a erosão do substrato. Nos casos de maiores declividades um escalonamento da biovaleta pode ser realizado com o uso de barreiras físicas que podem ser projetadas tais como placas pré-moldadas, muros de arrimo, alvenarias, etc, ou com uso de elementos naturais como pedras de maior tamanho dispostos ao longo do leito.

A solução de biovaletas é bastante eficiente para o tratamento das águas provenientes de ruas e estacionamentos. 


\subsection{3}

\section{Lagoa Pluvial}

Nos casos de maior disponibilidade de área contínua e de uma necessidade de armazenamento temporário de um grande volume de água nos momentos de precipitação, podem ser criadas as lagoas pluviais, as quais se destacam pela capacidade de reter no período entre os eventos de precipitação, uma parte das águas, configurando-se como um alagado construído. A variação do nível da água constitui a sua capacidade de armazenamento durante as chuvas, definida pela cota de transbordamento do sistema.

Tal como nos modelos anteriores, tem uma solução de drenagem associada ao uso de vegetação que contribui para a retenção de parte da carga poluidora através da fitorremediação.

Por suas características de maior estabilidade ambiental, a presença constante da água, associada a composição de vegetação aquática e mata ciliar passa a configurar precioso habitat para animais silvestres assim como áreas de lazer para a população local e espaços de notável beleza cênica para o espaço urbano.

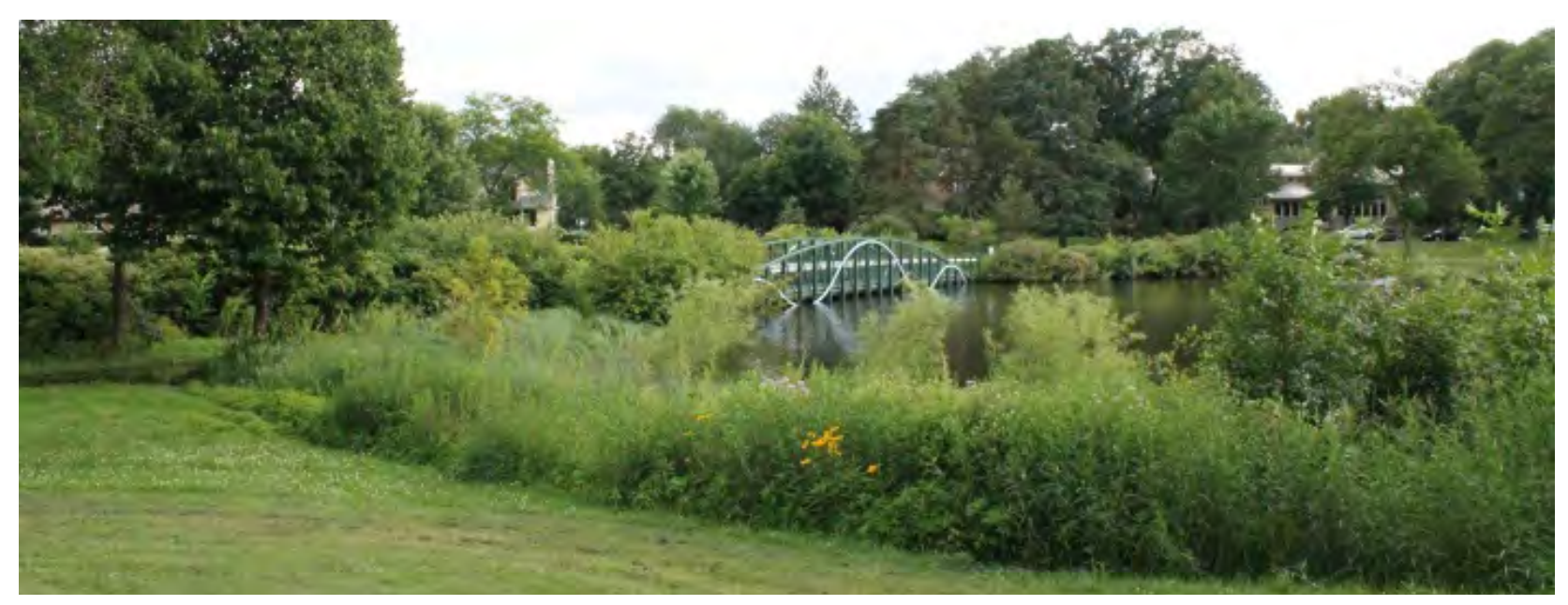

Foto 20 | Exemplo de lagoa pluvial resultado do projeto Southwest Lake Calhoun Wetland Ponds, promovido pelo Minnehaha Creek Watershed District (MCWD). O programa focou no manejo das águas das chuvas na sub-bacia dos Twin Lakes, com foco na recuperação da qualidade da água do lago Calhoun através da construção de lagoas pluviais para retenção de poluentes. 0 projeto também incluiu uma ponte de pedestres, decks de contemplação, trilhas e plantio de vegetação aquática e ripária. Na foto, momento de cheia máxima da lagoa pluvial, em julho/2014. Autor: Gerson Amaral - 2014 


\subsection{4 \\ Ilhas Flutuantes}

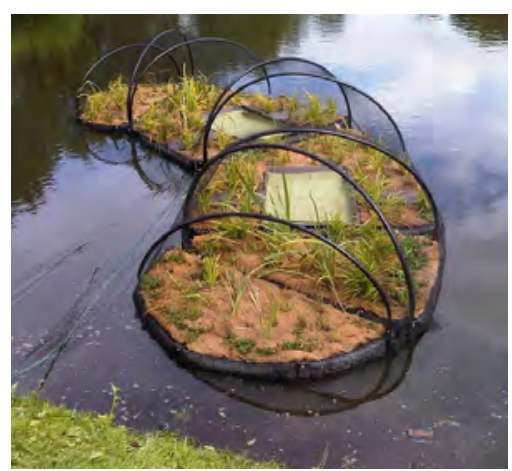

Foto 21 | Exemplo de ilha flutuante. Fonte: <http://www.biomatrixwater.com/>. Acesso em 15/04/2015.

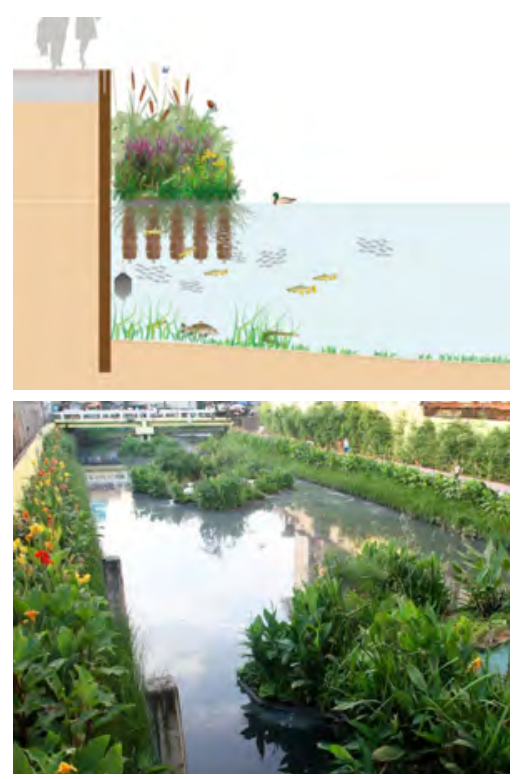

Foto 22 | Representação esquemática das ilhas flutuantes para suporte de vegetação ripária. Abaixo, exemplo da aplicação da tecnologia em um canal em Manila, capital das Filipinas. Fonte: <http://www.biomatrixwater. com>. Acesso em 15/04/2015.
A capacidade de retenção e processamento de poluentes das lagoas pluviais pode ser incrementada através da adoção de técnicas de fitorremediação como as Ilhas Flutuantes. Consistem em estruturas flutuantes que garantem o suporte de vegetação aquática e promovem a criação de habitat para animais aquáticos e melhorias paisagísticas para o corpo d'agua. A estrutura de raiz que se desenvolve debaixo da água constitui um filtro biológico que promove a absorção e transformação metabólica dos nutrientes e impurezas da água, trazendo uma melhoria substancial na sua qualidade e reincorporando os nutrientes à cadeia alimentar, minimizando os processos de eutrofização do corpo hídrico.

A mesma solução pode ser utilizada para recuperação das margens de rios e canais degradados pela poluição e impermeabilização de suas margens, reintroduzindo vegetação ripária em estruturas flutuantes. Além da notável melhoria paisagística, a solução promove melhorias na qualidade da água, aumenta a biodiversidade e o habitat para fauna local em solução de baixo impacto e baixo custo. 


\subsection{5}

\section{Teto Verde}

Solução já largamente utilizada e comprovadamente eficiente não só pelos benefícios em relação à detenção da água como também pelas melhorias ambientais promovidas para o conforto térmico da arquitetura sobre a qual se implanta.

Trata-se da criação de uma cobertura total ou parcial de edificações compostas por uma massa vegetal plantada em uma camada de substrato sobre camada de armazenamento e drenagem das águas de chuva e irrigação.

0 isolamento promovido traz a a melhoria do desempenho térmico da edificação e a diminuição do volume de escoamento superficial, aliviando a demanda sobre o sistema de drenagem. 0 volume de substrato e a tecnologia empregada permitem as mais variadas composições de jardim, desde gramados, arbustos e até pequenas árvores são possíveis.

O mercado brasileiro já vem oferecendo uma gama de produtos industrializados especializados na confecção de soluções de teto verde, permitindo a sua implantação nas mais diversas situações e com diferentes capacidades de armazenamento de água em seu interior. Sua aplicação é possível tanto em novas edificações como em edificações existentes, pela reconfiguração de suas cobertas. A área verde criada pode adquirir configurações diversas, combinadas com passarelas, áreas pavimentadas e mobiliário, tornam-se novas áreas de uso ao ar livre. A manutenção dessas áreas é similar a qualquer jardim. Para minimização da manutenção, é preferível o uso de espécies nativas, melhor adaptadas ao clima local.

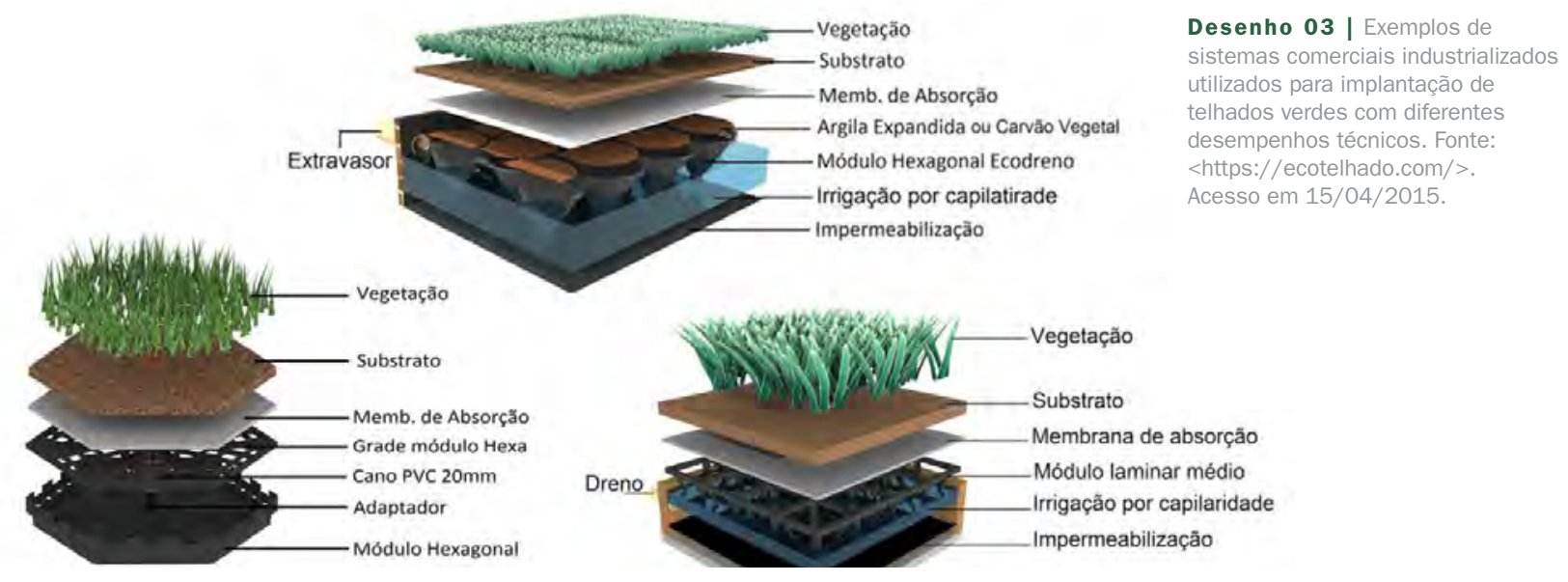




\subsection{6}

\section{Pavimentos Drenantes}
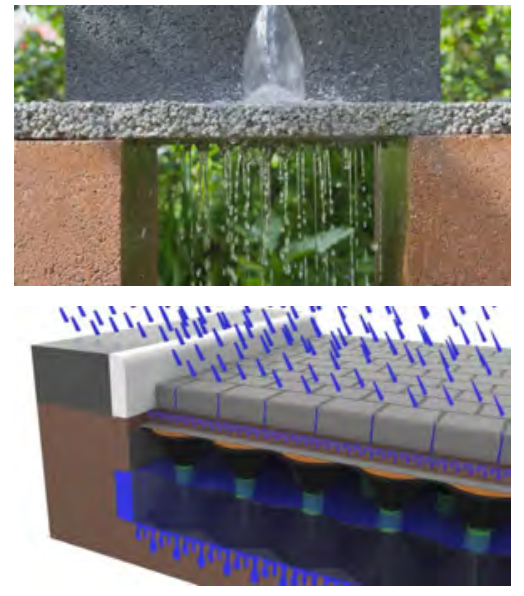

Foto 23 | Exemplos de pavimentação drenante. Solucões técnicas permitem o armazenamento subterrâneo, potencializando a infiltração no solo e reduzindo os efeitos de enxurrada. Fonte: <https://ecotelhado.com/> Acesso em 15/04/2015.
Pavimentos drenantes tratam ou reduzem o escoamento superficial (runoff) ao serem confeccionados com materiais porosos ou semi-porosos na pavimentação de estacionamentos, vias locais, vias de acesso, áreas de manobras, passeios e calçadões. Esse tipo de pavimentação permite o armazenamento subterrâneo ou a infiltração da água no solo, contribuindo para a redução de enxurradas se comparado com superfícies tradicionais pavimentadas com concreto ou pavimentação asfáltica. 0 escoamento superficial percola no solo, contribuindo para a recarga dos aquíferos e retendo os poluentes carreados. Outras soluções como blocos intertravados de concreto e piso-grama, dependendo da forma de assentamento e preparo de suas camadas de base, promovem também os mesmos efeitos de infiltração e minimização de enxurradas.

O uso de pavimentação drenante deve ser precedido pela investigação da capacidade de infiltração do solo local, considerando as alterações preliminares como cortes, aterros ou obras de compactação que podem alterar significativamente o desempenho da solução. 0 tratamento das subcamadas de assentamento garantem o aumento da capacidade de infiltração e a estabilidade física da superfície.

A promoção de infiltração das águas pluviais no solo não é recomendada para áreas críticas de fontes poluidoras tais como postos de gasolina, estacionamentos de carga/descarga, oficinas mecânicas, etc; pelo alto risco de contaminação do lençol freático. 


\subsection{7}

Trincheiras ou Poços de Infiltração

Também denominadas como dreno francês ou poços secos são técnicas de coleta e infiltração das águas pluviais oriundas de cobertas e áreas pavimentadas. As águas são diretamente conduzidas do sistema de drenagem para uma vala, a qual armazena o volume nos vazios da trincheira preenchida por pedrisco ou brita e lentamente é absorvida pelo solo. Os termos de dreno francês e poço seco são frequentemente usados como sinônimos, uma vez que desempenham a mesma função, no entanto, a sua concepção e aplicação diferem ligeiramente. Um dreno francês é uma trincheira subterrânea rasa com tubos perfurados que funcionam ao longo da parte inferior. Um poço seco típico é uma trincheira mais profunda e mais curta escavada com tubos perfurados que são executados tanto verticalmente como horizontalmente através da pedra. Sua aplicação serve a pequenas áreas de contribuição devido a limitada capacidade de armazenamento. (Center for Watershed Protection, 2007)

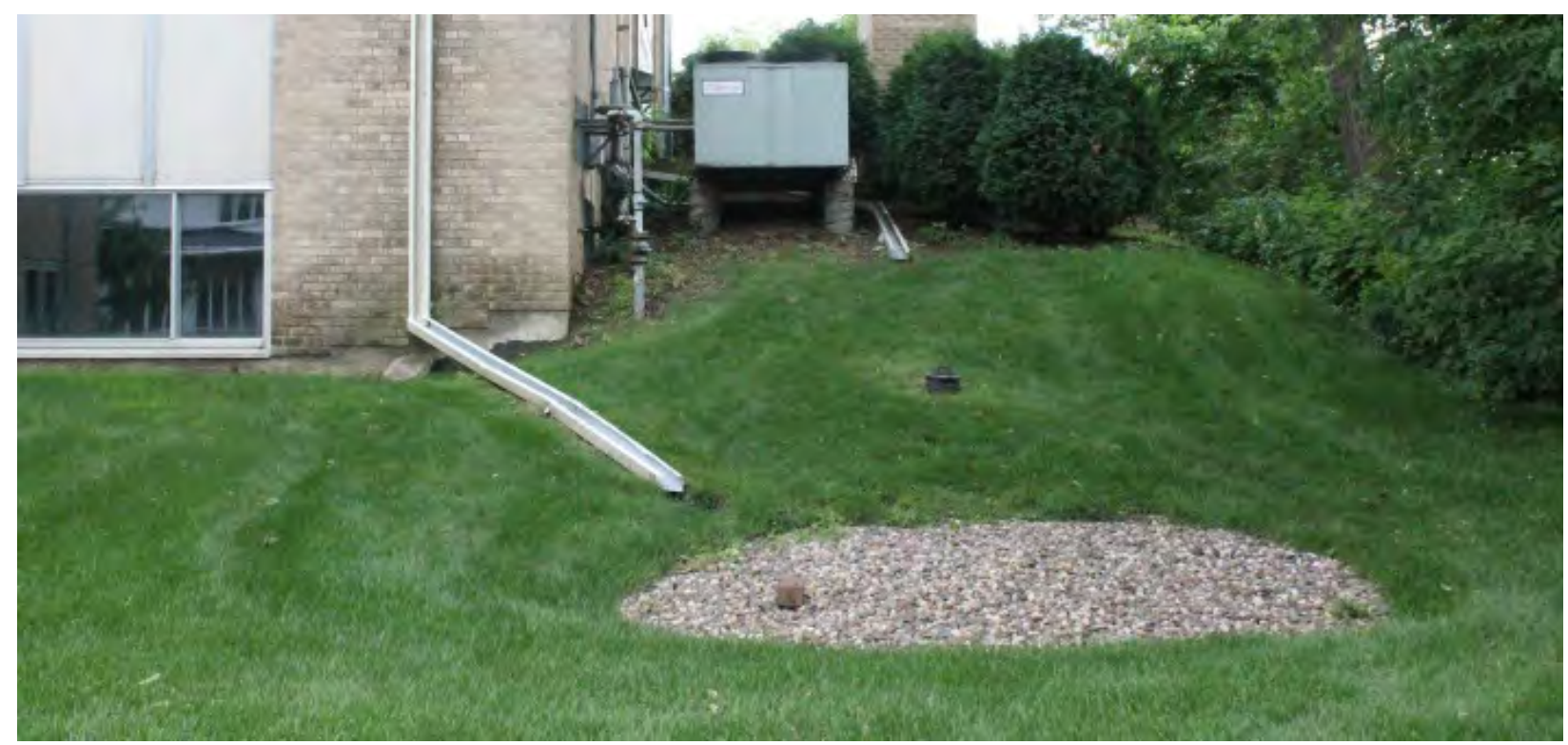

Foto 24 | Exemplo de poço de infiltração. Local: St. Mary's Greek Orthodox Church,

Minneapolis, EUA. Autor: Gerson Amaral - 2014. 
2.1.8

Grade Verde

As diferentes técnicas de Infraestruturas Verdes atendem a distintas demandas e adaptam-se a diversos contextos físicos e espaciais. Adicionalmente, um dos conceitos das Infraestruturas Verdes é a sua capacidade de integração e complementaridade às infraestruturas existentes, trabalhando conjuntamente para promover a melhoria do desempenho dentro das capacidades máximas de cada contexto. Teríamos, pois, a combinação de diferentes soluções em um recorte espacial, com cada solução atuando como subsistemas de um sistema maior.

\footnotetext{
"As grades verdes consistem na combinação das diversas tipologias anteriores, em arranjos múltiplos, que acabam por conformar uma rede de intervenções para setores urbanos inteiros. Desse modo consegue-se que as soluções técnicas mais efetivas e eficientes sejam aplicadas onde mais apropriadas, tirando-se partido das tipologias mais adequadas para os diversos pontos, aumentando o desempenho geral do sistema. Se, por exemplo, em alguns trechos, os solos são argilosos e a topografia se apresenta íngreme, e, portanto, aqueles não se apresentam adequados para uma infiltração, com uma grade verde o escoamento superficial pode ser conduzido até outros lugares para infiltração ou armazenamento." (PELLEGRINO \& CORMIER, 2008, pp. 136-137)
}

Todas as soluções de infraestruturas verdes apresentadas focam na contenção das águas principalmente nas primeiras chuvas, para a retenção da poluição difusa e redução do escoamento superficial da área de contribuição. 
As soluções de Infraestrutras Verdes são extensíveis também a intervenções nas próprias linhas de drenagem, nos componentes da macrodrenagem, através do aumento da rugosidade do canal de escoamento pela introdução de barreiras com elementos naturais (rochas, troncos, fibras naturais, estacas, etc.), elementos construídos (muros, diques, gabiões, defletores, vertedouros, etc), pela introdução de vegetação ciliar e aquática ou pelo simples redesenho do curso, introduzindo sinuosidades no leito.

Tanto quanto possível as soluções adotadas deverão primar pela recuperação do desempenho ambiental de cada um dos componentes da bacia hidrográfica, promovendo não só a meIhoria na qualidade da água, promoção da infiltração e redução dos picos de cheia, mas também aumentando a biodiversidade local e criando habitat para abrigo da fauna silvestre, em solução ambientalmente eficiente e urbanisticamente sustentável, com melhorias substanciais para a qualidade do meio ambiente urbano. 


\section{2}

Investigação e prática na aplicação das infraestrutras verdes

Como se percebe, a busca por soluções infraestruturais que requalifiquem o espaço construído de forma a eliminar os problemas ambientais e urbanísticos gerados pelo modo tradicional de construir levou a compreensão da importância de dois elementos fundamentais a serem trabalhados para a para a obtenção de uma qualidade ambiental do espaço urbano: a água e a cobertura vegetal.

Partindo dessa constatação, vimos surgir na Europa um movimento de busca por soluções integradas de desenvolvimento nomeado Blue Green Dream (Sonho verde e azul).

\subsection{1}

\section{Blue Green Dream}

O projeto Blue Green Dream, liderado pelo Imperial College London, tem participação de 4 países europeus (França, Alemanha, Holanda e Reino Unido) e foca no desenvolvimento de produtos e serviços inovadores com foco nas infraestruturas urbanas considerando os seus impactos para o meio ambiente global. (Fonte: Climage-KIC. Disponivel em: <http://www.climate-kic-centre -hessen.org/blue-green-dream.html>. Acesso em 12/01/2016)

O projeto enfatiza os múltiplos benefícios alcançados pela integração das infraestruturas de água (b/ue) e de elementos vegetais (green), que se materializam através de, por exemplo, um planejamento adequado de canais de irrigação e drenagem, pelo uso de jardins filtrantes, biovaletas, lagoas pluviais e tetos jardins, e comprovando sua eficiência para a distribuição das águas da chuva estimulando a evaporação e diminuição do risco de inundações, assim como a redução 


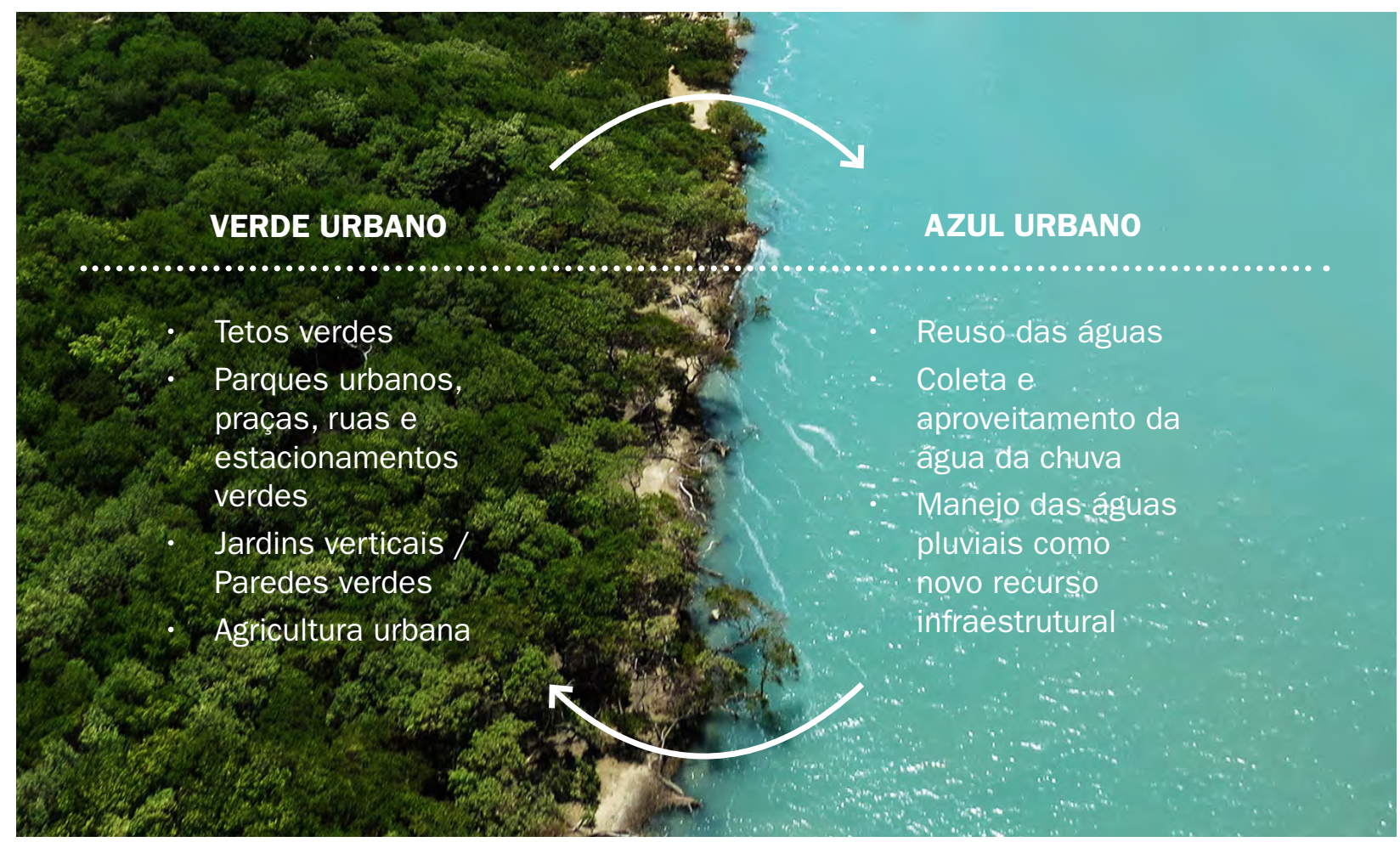

considerável dos efeitos das ilhas de calor no meio urbano, tudo isso associado a redução da poluição, ao incremento da biodiversidade e criação de habitats.

A estratégia do movimento busca identificar quais serviços a água e a vegetação fornecem naturalmente e como eles podem ser aproveitados tanto para o bem estar da sociedade como também para o próprio meio natural.

A integração dos serviços ecossistêmicos da cidade constitui o objetivo norteador da estratégias adotadas promovendo o aumento das interações entre serviços essenciais, contribuindo entre si para a redução dos custos de implantação, diminuição dos gastos energéticos e dos desperdícios materiais, aumentando a eficiência e a qualidade de vida.
Gráfico 03 | Adaptado de Maksimovic. Fonte: MAKSIMOVIC, Cedo et al. Blue-Green innovations in spatial planning. 2014.

Disponível em: < http://resilient-cities.iclei.org/ fileadmin/sites/resilient-cities/files/Resilient Cities_2014/PPTs/E/E2_Maksimovic.pdf>.

Acesso em 12/01/2016. Autor: Gerson Amaral. 


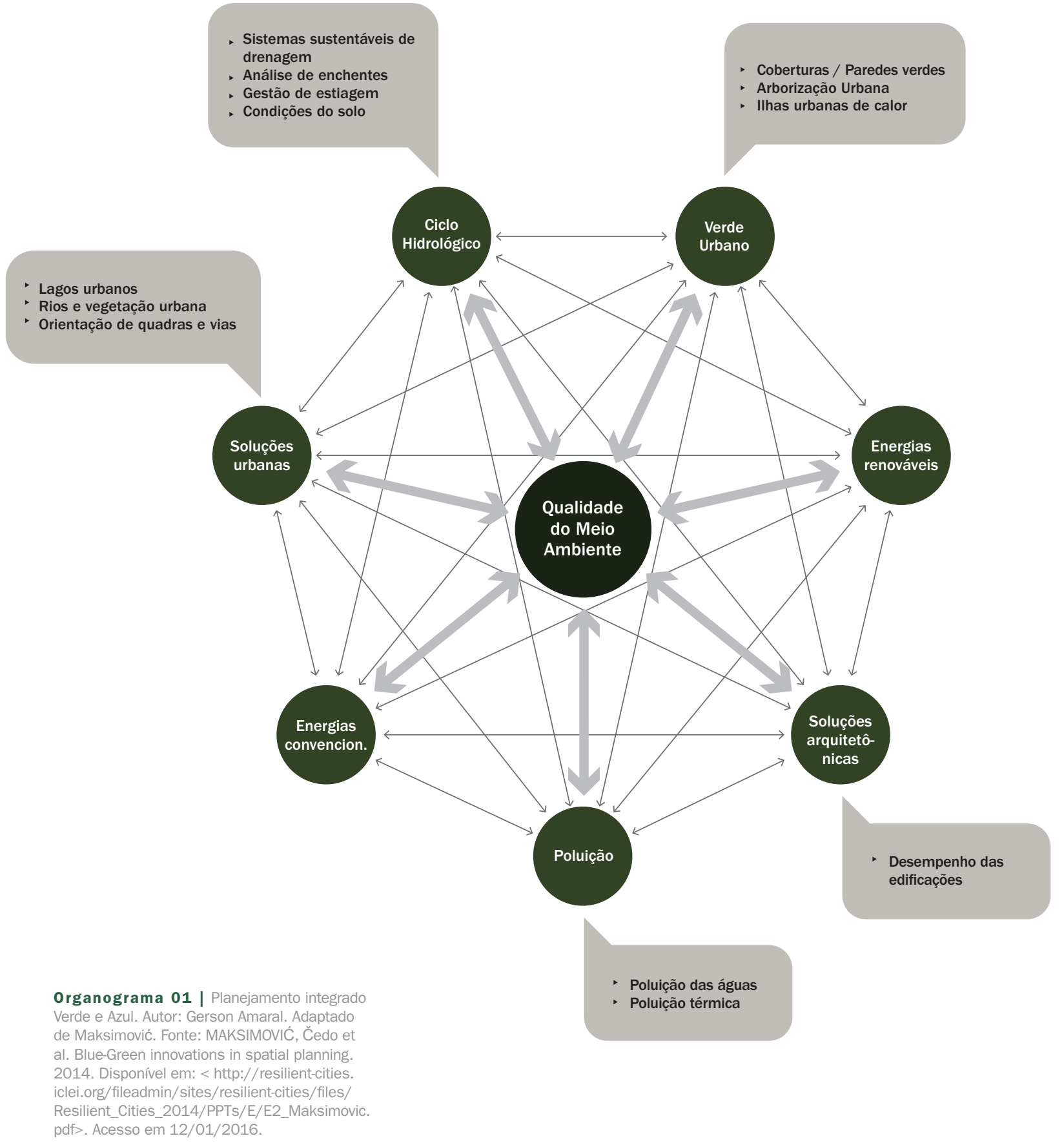


A ideia é a criação de modelos, ferramentas e metodologias através do compartilhamento da expertise de diversos parceiros envolvidos. Essas ferramentas serão testadas e demonstradas em cidades como Berlim, Londres, Paris e Roterdã, em uma combinação de novas infraestruturas com a requalificação de infraestruturas existentes.

Um exemplo de aplicação prática e pesquisa proposta pelo grupo é o trabalho realizado na cobertura ajardinada da École des Ponts ParisTech chamada de Blue Green Wave.

O edifício da escola, localizada em Marn-la-Vallée, Paris, consiste em um edifício de 200 metros de comprimento composto por uma laje jardim ondulada que configura um grande parque central do campus e da cidade. 0 edifício se integra a paisagem como uma longa ondulação na topografia com um tratamento paisagístico que torna-se uma extensão das áreas verdes do campus. A abordagem dessa arquitetura integra as inovações tecnológicas que promovem o desenvolvimento sustentável através da sua relação com o meio ambiente, a gestão de energia, a conservação e manutenção, o aproveitamento da energia geotérmica para o aquecimento de seus ambientes e o conforto visual, como consequência de sua contribuição para a paisagem.

O trabalho do Blue Green Dream sobre esse edifício trata da instalação de um jardim sobre três módulos de coberta ondulada com o objetivo de monitorar a distribuição e o impacto das enxurradas sobre o substrato e fluxo de poluentes, o monitoramento das taxas de infiltração e escoamento superficial sobre cobertas vegetadas assim como o monitoramento do desempenho da filtragem biológica promovida pelo sistema.
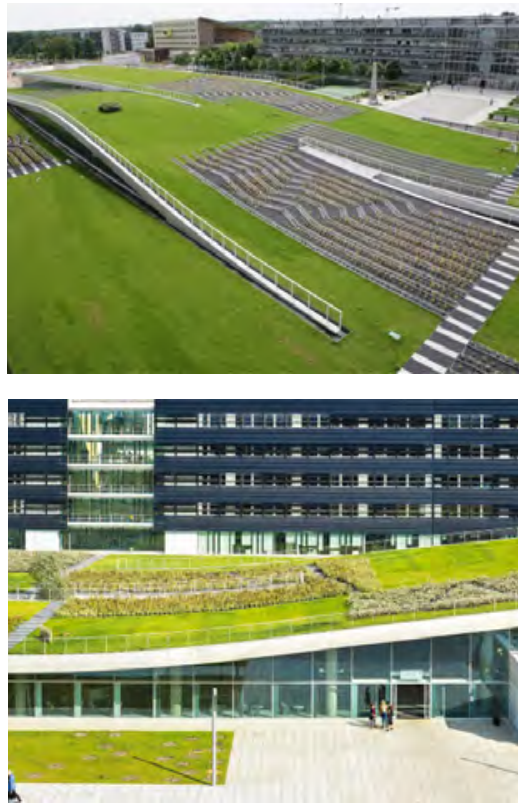

Fotos 25 e 26 | Cobertura verde ondulada da École des Ponts ParisTech. Fonte: Revista Domus. Disponivel em: <http://www.domusweb.it/en/ architecture/2015/02/11/concrete_wave.html> Acesso em: 05/02/2016. 
O edifício torna-se um grande laboratório de investigação do desempenho dessas soluções seja para o manejo das águas pluviais, seja na manutenção desse tipo de coberta e seus benefícios para eficiência energética as construções.

Outro local previsto para as demonstração do Blue Green Dream será a coberta do antigo aeroporto Tempelhof. Essa coberta - famosa por ser considerada a terceira maior coberta única do mundo - está sendo adaptada para coleta e reuso das águas pluviais.

O objetivo dessa pesquisa é demonstrar quanto energia pode ser poupada pelo sistema de drenagem tradicional de Berlim e quanto da água poderá ser efetivamente reaproveitada no uso do edifício, minimizando o impacto que a imensa área impermeabilizada provoca no volume de escoamento superficial.

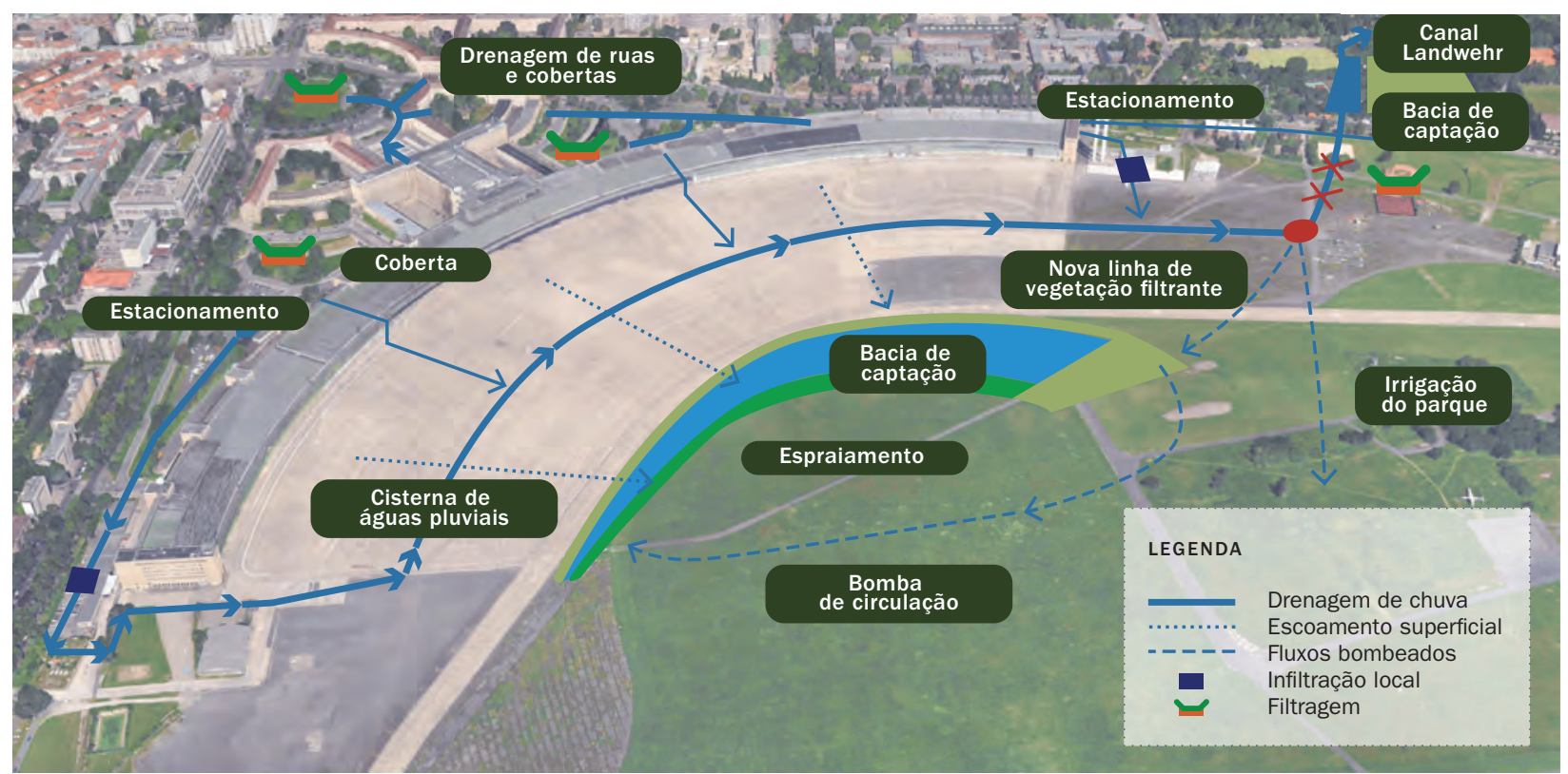

Gráfico 04 | Novas soluções de drenagem para o aeroporto Tempelhof. Autor: Gerson Amaral. Adaptado de: Maksimovic. Fonte: MAKSIMOVIC, Cedo et al. Blue-Green innovations in spatial

planning. 2014. Disponível em: < http://resilient-cities.iclei.org/fileadmin/sites/resilient-cities/files/ Resilient_Cities_2014/PPTs/E/E2_Maksimovic.pdf>. Acesso em 12/01/2016. 


\subsection{2}

\section{Minnesota Landscape Arboretum}

Um pequeno exemplo americano de investigação sobre o desempenho de novos sistemas de manejo das águas pluviais é o modelo de drenagem das águas pluviais criado pelo Minnesota Landscape Arboretum. A construção do modelo foi concluída em 2003 e trata-se de um modelo educacional concebido através de parceria do Minnehaha Creek Watershed District, o Conselho Metropolitano de Minneapolis, Bogert Products, Inc., e o Minnesota Landscape Arboretum.

O experimento educacional está localizado no estacionamento defronte ao Marion Andrus Learning Center dentro das dependências do Minnesota Landscape Arboretum. 0 modelo foi desenhado para demonstrar como o volume de escoamento superficial das águas das chuvas pode ser reduzido modificando as características de infiltração em diferentes superfícies.

0 modelo é dividido em 5 áreas iguais de contribuição do estacionamento com diferentes taxas de permeabilidade, indo desde quase $100 \%$ de área permeável até $100 \%$ de pavimentação impermeável.
Foto 27 | Modelo de drenagem das águas pluviais criado pelo Minnesota Landscape Arboretum de cunho educacional. Fonte: Google Earth. Acesso em 05 de fevereiro de 2016.

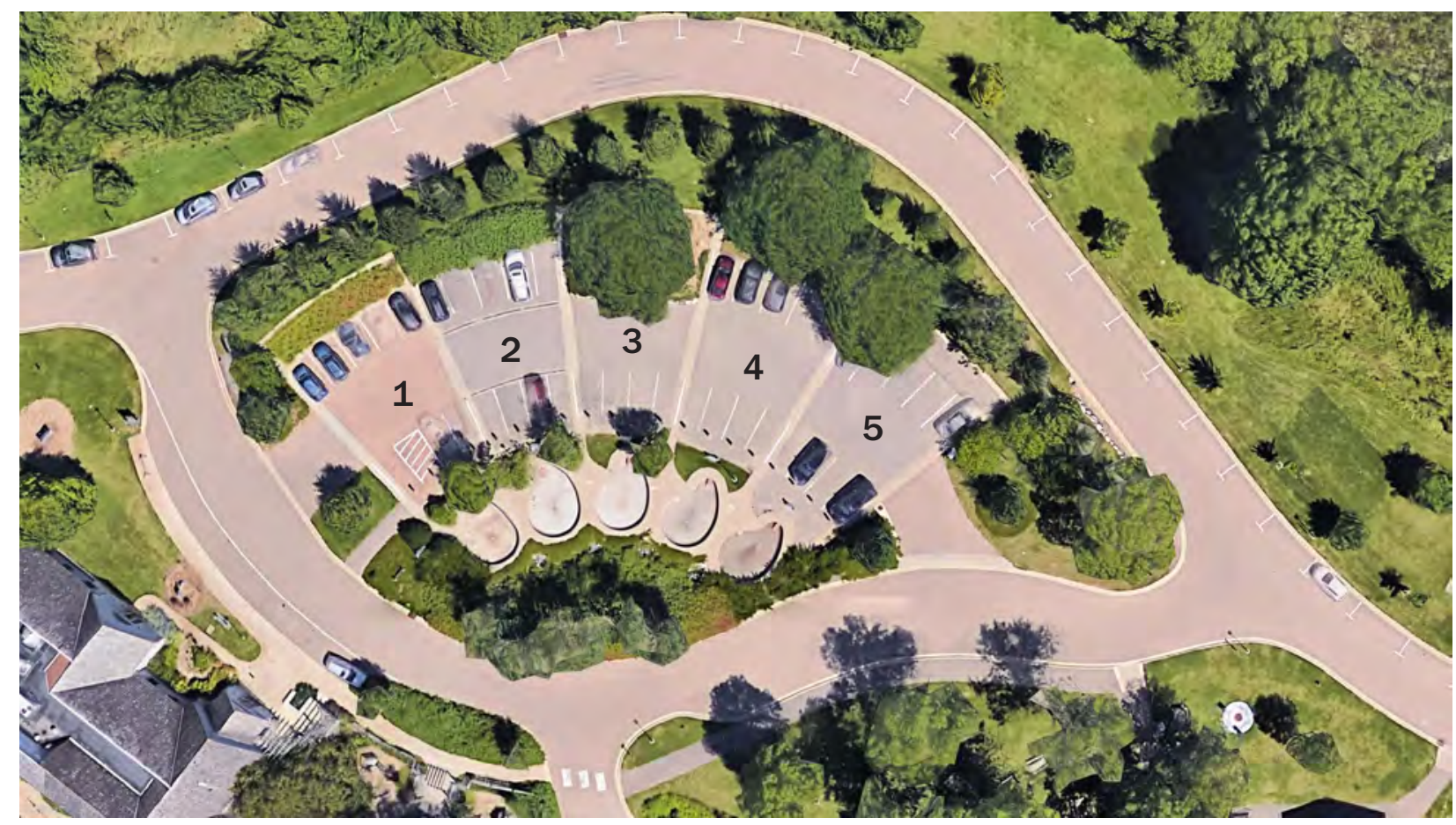




\section{Área 01}

Essa é a área com maior percentual de superfícies permeáveis. A água das chuvas é absorvida por duas áreas vegetadas e pela pavimentação permeável do estacionamento. A infiltração da superfície permeável é incrementada por uma camada de $33 \mathrm{~cm}$ de pedrisco calcário com trincheiras de infiltração abaixo.
Depois de uma precipitação pluviométrica de $25,4 \mathrm{~mm}$, o nível do reservatório correspondente subiu $38 \mathrm{~mm}$. O escoamento superficial foi de cerca de 1.287,04 litros.

\section{Área 02}

A área 02 tem quase a mesma superfície pavimentada da área 04 mas possui uma taxa de escoamento substancialmente menor. Isso se deve ao fato de possuir, em meio a área pavimentada, três grelhas de captação do escoamento com trincheiras de infiltração abaixo, permitindo a percolação no solo. Essa solução pode ser utilizada em estacionamentos e vias existentes. A trincheira é preenchida com brita e tem sua profundidade dimensionada com base na capacidade de absorção do solo.

Depois de uma precipitação pluviométrica de $25,4 \mathrm{~mm}$, o nível do reservatório correspondente subiu $63,5 \mathrm{~mm}$. O escoamento superficial foi de cerca de 2.157 litros.

\section{Área 03}

Essa área possui a maior superfície vegetada (portanto acomoda menos carros) dentre as áreas componentes do modelo. Um muro de arrimo em pedra foi adicionado para preservação de uma árvore existente que além de garantir uma sombra agradável nos meses de verão, maximiza a infiltração das águas pluviais na superfície ajardinada.
Depois de uma precipitação pluviométrica de $25,4 \mathrm{~mm}$, o nível do reservatório correspondente subiu pouco mais de $89 \mathrm{~mm}$. O escoamento superficial foi de cerca de 3.028,33 litros.

\section{Área 04}

A adição de duas faixas gramadas nessa área incrementou a absorção do escoamento superficial. Não existem barreiras físicas, portanto toda a água escoada no estacionamento é direcionada para a área gramada. A simples adição dessas faixas permeáveis reduziu o volume de escoamento superficial na área 04 pela metade se compararmos com o desempenho da área 05.
Depois de uma precipitação pluviométrica de 25,4mm, o nível do reservatório correspondente subiu $165,1 \mathrm{~mm}$. O escoamento superficial foi de cerca de 5.594,83 litros.

\section{Área 05}

Essa área possui pavimentação completamente impermeável. Toda a água da chuva corre superficialmente visto que não há qualquer área de contato da água com o solo abaixo da pavimentação, resultando nos maiores volumes de escoamento durante os períodos de precipitação.

Depois de uma precipitação pluviométrica de $25,4 \mathrm{~mm}$, o reservatório atingiu seu volume máximo e transbordou. A capacidade máxima do reservatório é de 10.300 litros. 
65\% pavimento permeável $20 \%$ concreto

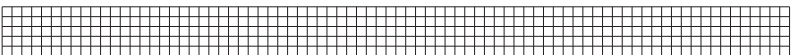
$80 \%$ da superfície total é permeável

\section{$64 \%$ asfalto}

$20 \%$ concreto

$15 \%$ jardim

\#\#半曲

$1 \%$ trincheira de infiltração

$16 \%$ da superfície total é permeável

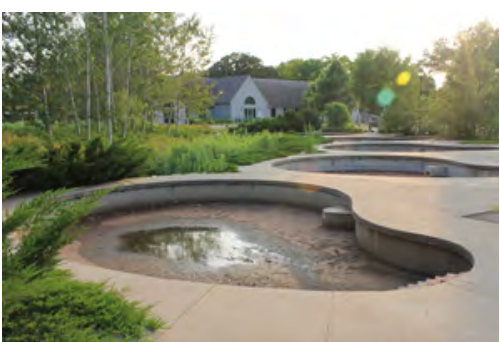

Foto 28 | Conjunto de reservatórios que recebem as contribuiç̧ões das diferentes áreas correspondentes de estacionamento. Autor: Gerson Amaral, 2014.

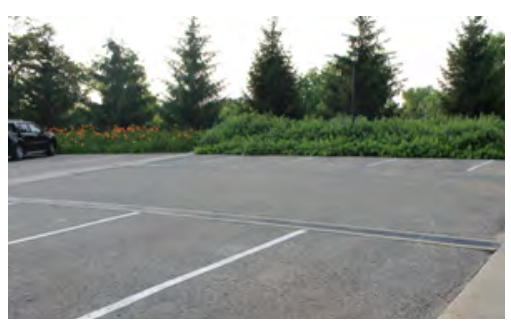

Foto 29 | Grelhas de captação com trincheiras de infiltracão presentes na Áreas 02 possuem contribuição significativa para a redução do volume de escoamento superficial. Autor: Gerson Amaral, 2014.

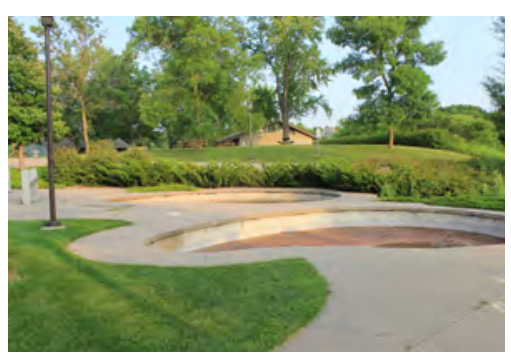

Foto 30 | Reservatórios 04 e 05 recebem as maiores contribuições de escoamento superficial por corresponderem às áreas mais impermeabilizadas. Autor: Gerson Amaral, 2014.

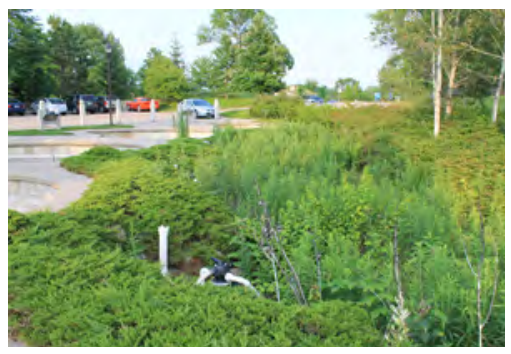

Foto 31 I Uma biovaleta vegetada adjacente ao modelo recebe toda a água excedente nos casos de transbordamento. Autor: Gerson Amaral, 2014. 


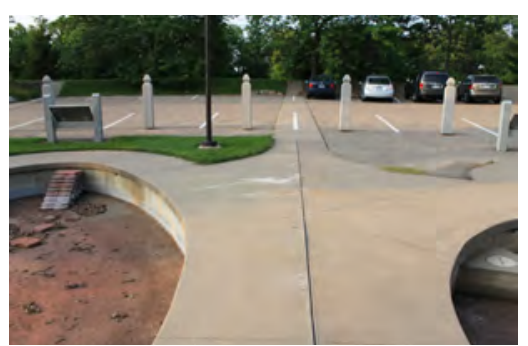

Foto 32 | Faixas de separação das diferentes áreas de contribuição.

Autor: Gerson Amaral, 2014
O escoamento superficial de cada área é conduzida reservatórios correspondentes onde o volume escoado pode ser medido e registrado nos eventos de precipitação. Um separador físico de concreto garante o isolamento das contribuições de cada uma das áreas para garantir que o escoamento superficial seja direcionado para o reservatório específico. Cada reservatório constitui apenas 7,4\% da área de área de contribuição.

Esse experimento demonstra de forma clara os benefícios que pequenas modificações na configuração da pavimentações consegue alterar significativamente o impacto das chuvas no solo e dinâmica hídrica superficial. Nota-se, nos resultados obtidos, como a adição de trincheiras filtrantes, mesmo que locadas pontualmente, possuem notável eficiência na promoção da infiltração e, portanto, diminuição do volume escoado superficialmente.

Importante salientar que o modelo experimental não objetivou fazer qualquer análise referente a qualidade da água escoada em cada uma das áreas de análise. 


\section{3}

\section{Infraestruturas Verdes no Brasil}

A introdução de novas práticas de manejo das águas pluviais é algo de introdução recente na realidade brasileira. 0 urbanismo sanitarista iniciado no Brasil ainda no século XIX pautou todo o desenvolvimento urbanístico do século XX e fincou profundas raízes na cultura brasileira de ocupação do território, caracterizando até os dias de hoje os processos de transformação da natureza para adequação a ocupação humana. (CANHOLI, 2005)

As profundas alterações no ciclo hidrológico nas áreas urbanas brasileiras decorrentes desse modelo de ocupação contribuem para o agravamento dos maiores desastres naturais das cidades brasileiras: as inundações e poluição crítica dos recursos hídricos. Tal fato que decorre da alteração substancial que a impermeabilização do solo, ocupação das margens dos rios e canalização leitos de drenagem natural promovem nas taxas de permeabilidade, aumentando o escoamento superficial e os volumes drenados pelos leitos fluviais nos períodos de precipitação.

Também como consequência desse fenômeno, verificamos o aumento do carreamento da poluição difusa encontrada em áreas urbanas que são conduzidas em taxas cada vez maiores para o sistema de drenagem que têm como destino os leitos dos rios e o mar. Como explica Tucci (2003, p. 36 apud GORSKI, 2010, p. 65), "as chuvas captam a poluição do ar, varrem a superfície das áreas urbanizadas contaminadas por componentes orgânicos e metais, carreiam resíduos sólidos e lixo urbanos, e transportam o esgoto despejado indevidamente na tubulação de drenagem." O transporte de sedimentos é uma grave ameaça aos rios urbanos, que têm seu leito cada dia mais reduzido, diminuindo sua vazão e sua capacidade de retenção das águas.

O enfrentamento de um amplo leque de problemas ambientais urbanos levou à crise ambiental experimentada pelas grandes e médias cidades na segunda metade do século XX. A reação veio através do reconhecimento e consolidação de trabalhos pioneiros, tais como os estudiosos da ecologia da paisagem 
e do urbanismo ecológico, os quais formularam, nas décadas anteriores, a compreensão do espaço urbano enquanto meio ambiente, o qual também se estrutura e se relaciona através de uma organização ecossistêmica de seus componentes. Tal como os já reconhecidos ecossistemas naturais, se reconheceu a necessidade de estabelecimento de um equilíbrio ambiental para o espaço urbano.

Essa nova compreensão levou a surgimento das primeiras intervenções infraestruturais que se contrapunham ao modelo adotado até então. Conforme afirma HERLING (2002):

\footnotetext{
"Em contraposição às propostas elaboradas no período anterior, de implantação de grandes sistemas de infraestrutura desvinculados de sua base física natural, as novas propostas visam propor a exploração dos recursos naturais vinculada à regeneração de sua base física. Estas propostas, ainda incipientes enquanto corpo técnico coeso, ganham força nas áreas de abastecimento de água, de esgotamento sanitário e de drenagem urbana."
}

Sob esse novo enfoque, no que tange ao tratamento das águas urbanas, tanto a alteração na dinâmica hídrica, com o aumento progressivo das vazões de pico, quanto à elevação das taxas de poluição difusa carreadas pelo escoamento superficial para as linhas de drenagem têm sido combatidas através de múltiplas estratégias de reformulação das infraestruturas urbanas e na conformação do espaço construído e natural de forma a eliminar ou minimizar seus efeitos no meio ambiente. Convencionou-se nomear essa nova abordagem, que busca regular os fluxos dos elementos naturais, especialmente a água, como Infraestruturas Verdes (IEV). Tal como coloca Benedict e McMahon (2006, p. 1 apud HERZOG, 2009, p. 29) Infraestruturas Verdes:

[... "é uma rede interconectada de áreas naturais e outras áreas livres que conserva os valores e funções do ecossistema natural, mantém o ar e a água limpos, e proporciona um grande leque de benefícios para o homem e a vida sil- 
vestre. Usado nesse contexto, infraestrutura verde é a estrutura ecológica para a saúde ambiental, social e econômica - em suma, nosso sistema de suporte de vida natural."

A aplicação das Infraestruturas Verdes nas cidades é pautada em intervenções em diversas escalas, com foque na conservação dos processos e fluxos, assegurando a conectividade. 0 equilíbrio buscado é dinâmico, portanto acontece em sintonia com o crescimento e desenvolvimento do espaço, alterando e exigindo adaptações ao longo do tempo em trabalho constante de manutenção.

Como já exemplificado, tais práticas já vêm se consolidando em diversos países, especialmente nos Estados Unidos, Canadá, China, Austrália e países da Europa, que já apresentam grande variedade de projetos que aplicam os conceitos da infraestrutura em espaços públicos e privados. Como exemplo notório, temos as cidades de Seattle e Portland que já apresentam um conjunto de tipologias de infraestruturas aplicadas a diferentes contextos e atendendo a diferentes funções. (PELLEGRINO \& CORMIER, 2008)

Pela diversidade e amplitude da aplicação do termo, é difícil precisar o momento de introdução do termo Infraestruturas Verdes no Brasil. Contudo, no conceito em que ele é trabalhado dentro do manejo das águas pluviais o termo foi primeiramente empregado em um curso promovido pela faculdade de Arquitetura e Urbanismo da Universidade de São Paulo (FAU -USP) tendo como convidado o arquiteto Paisagista Nathaniel S. Cormier ${ }^{8}$ no ano de 2004. O curso exemplificou a aplicação das diversas tipologias de IEV já em uso nas cidades de Portland e Seattle, e que gerou uma publicação, Infraestrutura verde: uma estratégia paisagística para água urbana ${ }^{9}$. A partir

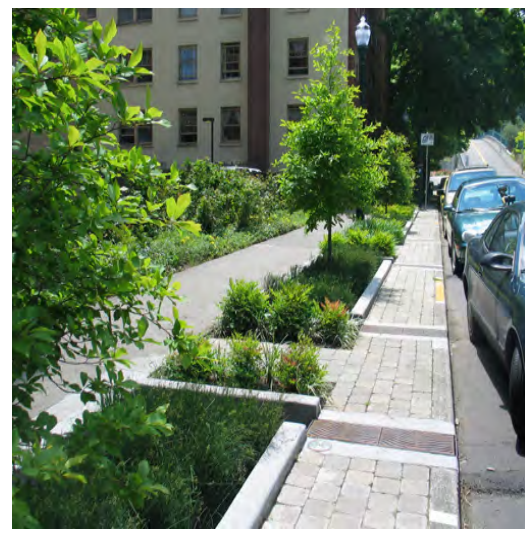

Foto 33 | Jardins de chuva já fazem parte do quotidiano da cidade de Portland, no Oregon -EUA. Fonte: <https://hpigreen. files.wordpress. com/2010/02/ 12th_ave_green_street.jpg>. Acesso em 18 de maio de 2015.

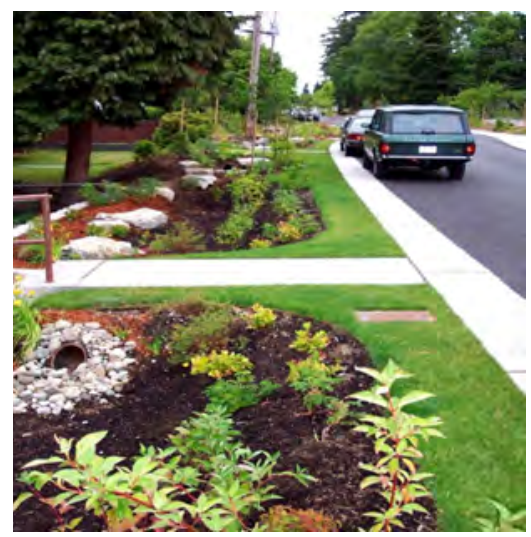

Foto 34 | Seattle SEA Street é exemplar no uso de biovaletas em um trabalho de retrofit de uma rua para melhor manejo de suas águas pluviais. Fonte: $<$ http://issuu. com/allyhangartner/docs/hangartner_ stormwaterthesisbook_pag>. Acesso em $18 \mathrm{de}$ maio de 2015. 
de então o termo foi definido na prática nacional e continuamente vem sendo aprimorado e investigado em pesquisas e experiências no âmbito do planejamento da paisagem e nos projetos de espaços livres.

Aplicações práticas no Brasil, contudo, ainda são poucas. As primeiras experiências concretizadas podem ser encontradas na cidade de São Paulo, como por exemplo, a sede da FUPAM (Fundação para a Pesquisa em Arquitetura e Ambiente) e a Praça das Corujas, ambos na zona oeste de São Paulo. (BONZI, 2015)

\subsection{1}

Praça das Corujas

A Praça das Corujas constitui um exemplo de retrofit de um espaço livre urbano que propunha o tratamento de toda sua área $\left(26.000 \mathrm{~m}^{2}\right)$ como uma grande infraestrutura de captação, condução e retenção das águas pluviais, recolhendo-as do entorno imediato e lançando-as em menor vazão e melhor qualidade no Córrego das Corujas, pela incorporação de soluções diversas como biovaletas, pisos drenantes, lagoas pluviais e colchões drenantes. A obra, concluída em 2009, não implantou fielmente os detalhes construtivos projetados em virtude da leitura equivocada do projeto e pouca familiaridade do empreiteiro com as soluções de bioengenharia, drenagem e paisagismo. Elementos de retenção das águas, projetados para incrementar a infiltração das águas no solo foram substituídos por correlatos impermeabilizados, tais como parte das biovaletas que tiveram seu leito concretado. As lagoas pluviais, por sua vez, não foram executadas. Somado a isso, a ausência de cobertura vegetal adequada não garantiu a estabilidade dos solos junto às biovaletas e margens do riacho. Por tais motivos, atualmente a praça opera com apenas parte de seu potencial de retenção e tratamento das águas pluviais. (MOURA, 2013)

A análise e compreensão dos problemas enfrentados quando da implantação da Praça das Corujas constitui importante ferramenta para o aprimoramento das tecnologias de Infraestruturas Verdes no Brasil. A própria ecologia da paisagem, com sua compreensão das relações estabelecidas entre os 
padrões espaciais, trouxe a visão do não equilíbrio ao planejamento da paisagem. A gestão dos recursos adotou o conceito de gestão adaptativa através do qual poderiam abordar incertezas e aprender-fazendo (learn-by-doing) através da concepção e projeto de ações de manejo como experimentos que poderiam se adaptar caso os resultados não saíssem como esperado, ou para aprender novos métodos quando as ações se provarem eficazes. (AHERN, 2011)

O planejamento da paisagem e planejamento urbano desde muito cedo adotaram os princípios da sustentabilidade, contudo tendiam para uma concepção estática, onde a sustentabilidade foi concebida como uma forma durável, estável, às vezes estereotipada, livre de falhas (fail-safe), que uma vez alcançada, poderia persistir por gerações. Se partirmos de uma perspectiva do não-equilíbrio essa visão de sustentabilidade e estabilidade é paradoxal na medida que a sustentabilidade torna-se algo improvável em uma condição estática da paisagem visto que está inserida em um contexto de perturbação e mudanças imprevisíveis. A postura segura-para-falhar (safe-to-fail) antecipa falhas e projeta sistemas de forma estratégica de modo que a falha está contida e minimizada. A resiliência teoricamente oferece uma nova perspectiva, ou possivelmente uma solução para este paradoxo da sustentabilidade. (op. Cit.)

O projeto de Infraestruturas Verdes da Praça das Corujas efetivamente implantado não cumpre plenamente os objetivos previstos em projeto, mas, com toda certeza, já oferece importante serviço ambiental no tratamento das águas urbanas em sua configuração atual e constitui grande avanço para consolidação dessa prática no contexto nacional. 


\subsection{2}

Modelo experimental de biorretenção
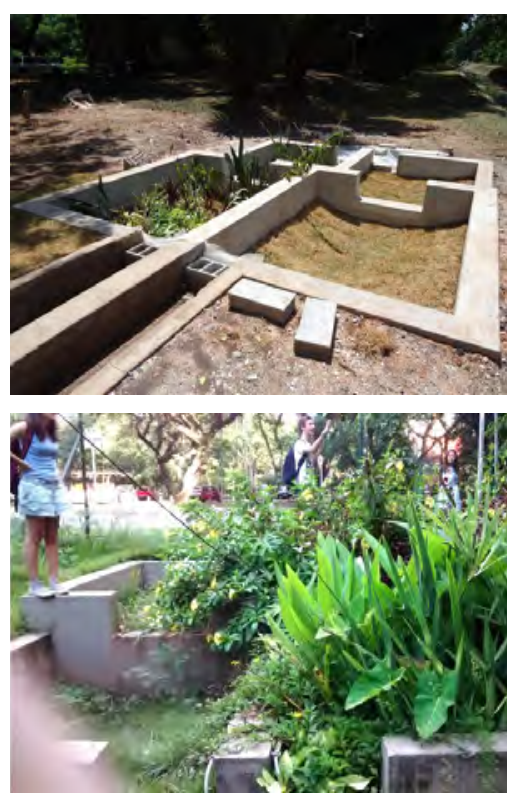

Fotos 35 e 36 | Modelo experimental executado na Cidade Universitária da USP. Acima, aspecto dos jardins em fase inicial de implantação (dezembro/2011). Abaixo, aspecto dos mesmos jardins dois anos depois (março/2014). Autor: Gerson Amaral.
A eficiência técnica das soluções de biorretenção propostas para a Praça das Corujas pôde ser confirmada através do experimento realizado pelo Programa de Pós-Graduação da Faculdade de Arquitetura e Urbanismo da Universidade de São Paulo FAU-USP, desenvolvido numa cooperação com a Escola Politécnica-USP, tendo recursos da FUNDEP, FCTH e LabVERDE. $O$ experimento consistiu na construção de um modelo de biorretenção em escala 1:1, implantado na Cidade Universitária Armando Salles de Oliveira (CUASO-USP), São Paulo, cuja função é o manejo dos escoamentos pluviais, utilizando uma matriz orgânica composta por vegetação, solo e agregados para retenção e tratamento iniciais localizados.

Conforme MOURA (2013), o experimento:

Composto por dois canteiros isolados entre si, os quais recebem águas pluviais da sarjeta da via adjacente, possuem substratos iguais, mas com coberturas vegetais distintas. Um recebeu cobertura com apenas uma espécie de gramínea e o outro recebeu diversas espécies de herbáceas e arbustos, em composição heterogênea. 0 experimento foi monitorado durante um ano, entre março de 2012 e março de 2013, quando foram coletados os dados referentes ao seu funcionamento e eficiência durante os períodos de precipitação, permitindo uma comparação do desempenho dos jardins para melhoria da qualidade da água através de sua passagem pelo sistema. (op. Cit.) 
Os resultados do experimento confirmaram a eficiência da biorretenção para diminuição da poluição difusa nas águas pluviais, reduzindo as cargas poluidoras acumuladas de $89,94 \%$ para o canteiro gramado e $95,49 \%$ para o canteiro com diversas espécies herbáceas, o qual foi comprovadamente mais eficiente. Esse experimento respalda tecnicamente a viabilidade e eficiência do sistema de biorretenção para a redução da poluição difusa pelo manejo das águas pluviais em espaços urbanos, no Brasil. (MOURA, 2013)

Não é à toa que as soluções de infraestrutura verde têm se disseminado no campo do planejamento da paisagem e nos projeto de infraestruturas, criando um novo horizonte de readequação dos espaços para adoção de melhores práticas de produção, manutenção e uso dos espaços construídos e dos espaços livres. As Universidade de São Paulo já direciona seu planejamento para ações desse tipo, dando início a criação de um plano de Viabilidade de Infraestruturas Verdes para o Campus da Universidade de São Paulo - Cidade Universitária Armando Salles de Oliveira- São Paulo- SP através da Oficina de Infraestruturas Verdes realizada na FAUUSP no ano de 2014, a qual foi ministrada pelo professor Paulo Renato de Mesquita Pellegrino e pela professora Maria de Assunção Ribeiro Franco. 0 trabalho consistiu no desenvolvimento de uma síntese diagnóstica do campus para elaboração de projetos de paisagens multifuncionais integradas às demais redes de infraestrutura de drenagem urbana, contemplando também aspectos de mobilidade e ecologia na busca de modelos tecnológicos inspirados nos processos naturais. Como resultado final da oficina foi elaborado um livreto que apresenta suscintamente os resultados do trabalho, apontando diretrizes projetuais que servirão como embriões para os futuros aprofundamentos sobre áreas e temas específicos com foco na construção de uma paisagem sustentável para o campus universitário. A oficina 

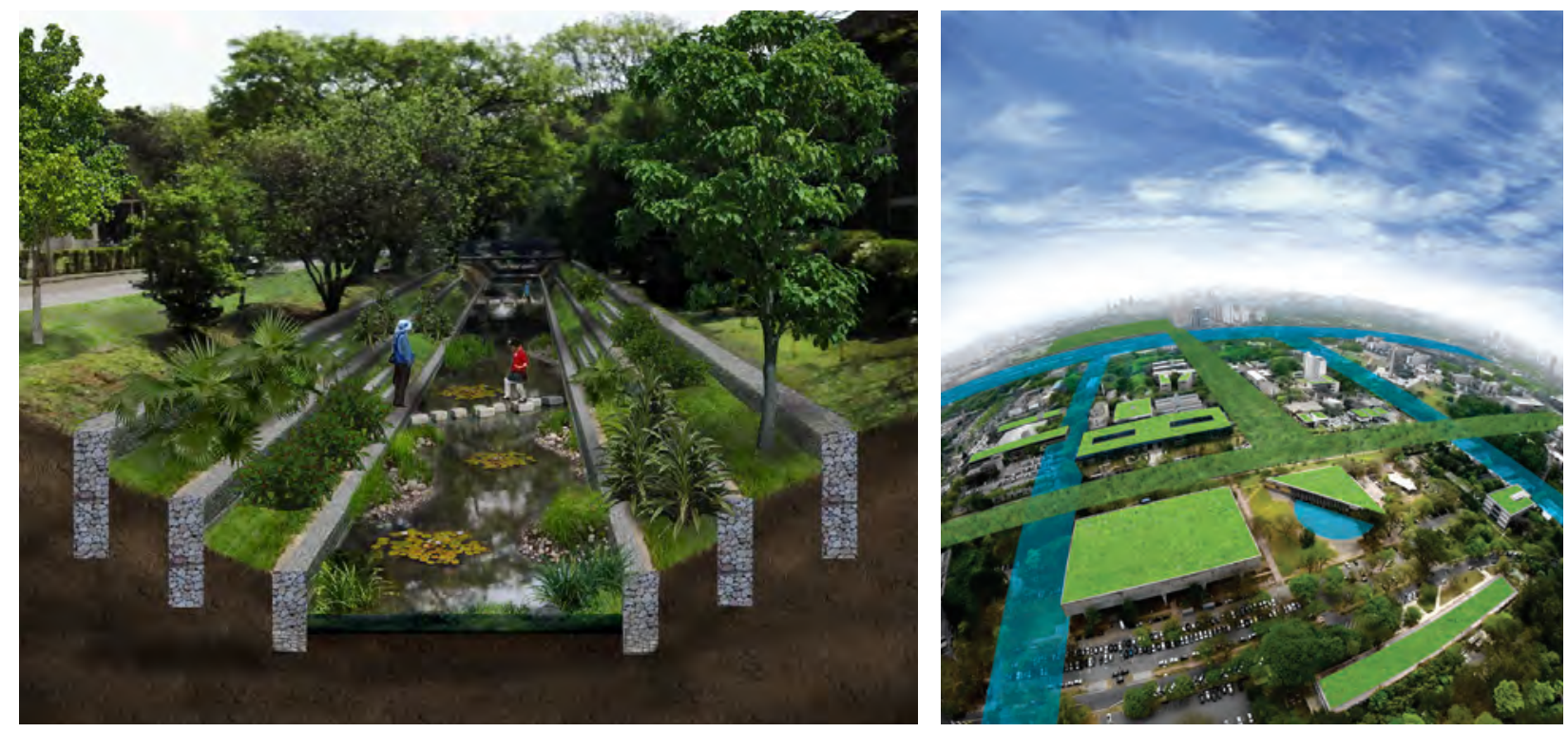

Desenho 04 | Produção gráfica da Oficina de Infraestruturas Verdes. Fotomontagem conceitual para o redesenho do canal do Tejo, incorporando novas soluções construtivas de baixo impacto, promoção da fitorremediação e aproximacão dos usuários com o recurso

Desenho 05 | Produção gráfica da Oficina de Infraestruturas Verdes. Fotomontagem. conceitual dos eixos verdes e eixos azuis, elementos concebidos para estruturação de uma paisagem mais sustentável para o CUASO. Autor: Gerson Amaral, 2014.

hídrico. Autor: Gerson Amaral, 2014.

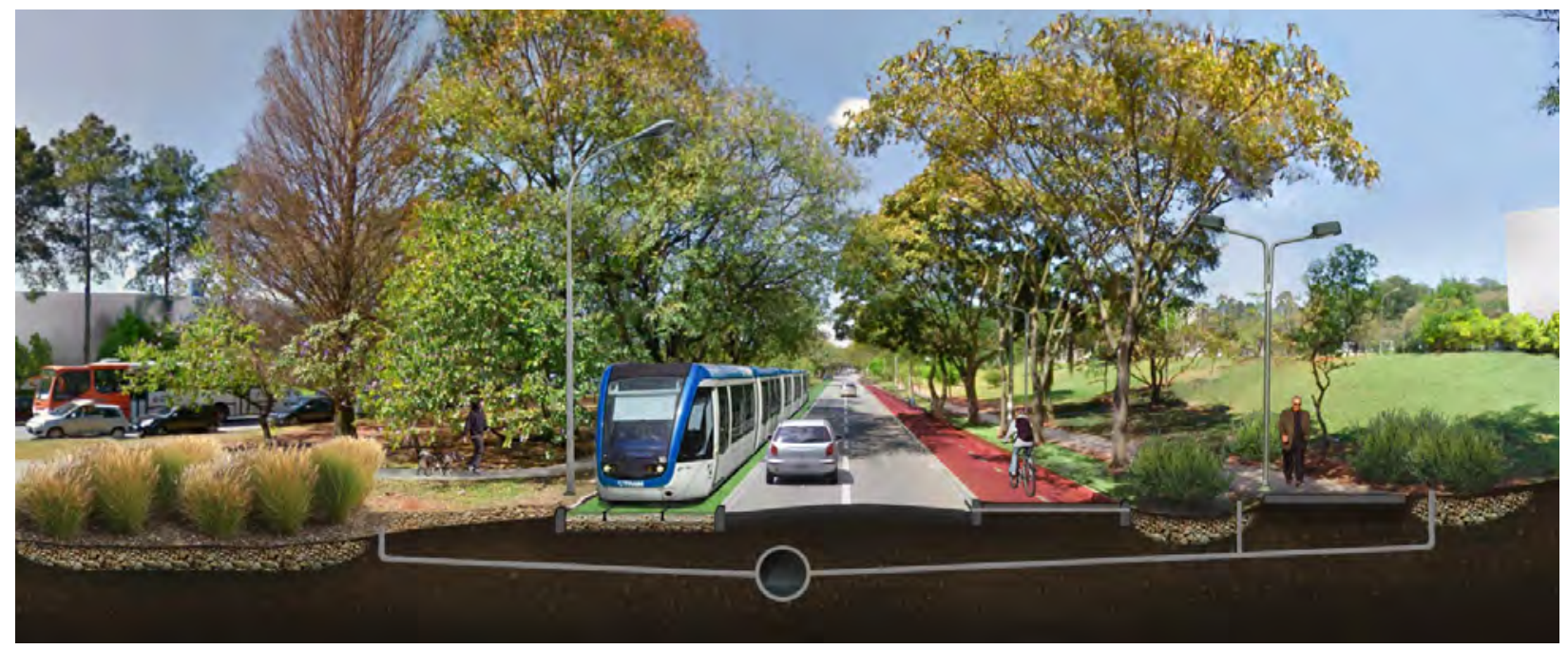

Desenho 06 | Produção gráfica da Oficina de Infraestruturas Verdes. Fotomontagem conceitual das diversas soluções de circulação, drenagem e paisagismo na incorporacãa de soluções infraestruturais de baixo impacto e maior resiliência. Autor: Gerson Amaral, 2014. 
também resultou em um artigo científico titulado Oficina de Projeto do LABVERDE para implantação de Infraestruturas Verdes no Campus USP - Cidade Universitária, publicado na revista LABVERDE $n^{\circ} 09$, que abre a discussão dessas ideias para todos aqueles interessados em contribuir para o assunto.

Os resultados obtidos com essas primeiras experiências já vem promovendo a disseminação desse método de planejamento em outras porções do território brasileiro. A presente dissertação apresenta, pois, um dos primeiros projetos de drenagem urbana que aplica efetivamente os conceitos de infraestrutura verde no contexto climático do semiárido brasileiro, dentro da região metropolitana de Fortaleza. Trata-se, portanto, do projeto de drenagem urbana do campus da Fiocruz no Ceará, equipamento com certificação ambiental AQUA que exigiu o mais alto padrão de controle no quesito Gestão das Águas, impulsionando o conjunto de projetistas a buscar as melhores soluções de drenagem em voga para alcançar o desempenho exigido. 0 contexto de sua implantação e as características do empreendimento serão abordados no capítulo que segue. 


\section{Campus Fiocruz Ceará: Primeiras aplicações das infraestruturas verdes no contexto do semiárido}

\section{1}

Urbanização x recursos naturais:

Uma breve caracterização das últimas intervenções na região metropolitana de Fortaleza

Durante todo o século XX, a capital cearense assistiu a um vertiginoso crescimento populacional que foi fruto, majoritariamente, da acolhida de centenas de milhares de sertanejos que fugiam das precárias condições de vida no interior, notadamente pela falta de investimentos no campo e dificuldade de convivência com a escassez hídrica nos anos de maior estiagem.

Seguindo o mesmo padrão predatório de ocupação do território desenvolvido no Brasil, o crescimento da cidade de Fortaleza e das cidades próximas se pautou na ocupação extensiva do solo, impulsionado pela especulação imobiliária e o crescimento industrial. A expansão da sua malha urbana aconteceu de forma relativamente fácil pela ausência de acidentes topográficos que impusessem limites ao seu crescimento. Apenas as áreas de campos de dunas constituem as zonas de maior irregularidade de relevo em faixa próxima ao litoral.

Por outro lado, o território encontra-se permeado por uma rica rede de drenagem composta por pequenas e médias bacias hidrográficas, características dos tabuleiros litorâneos cearenses, formando riachos, lagoas e manguezais. São exatamente
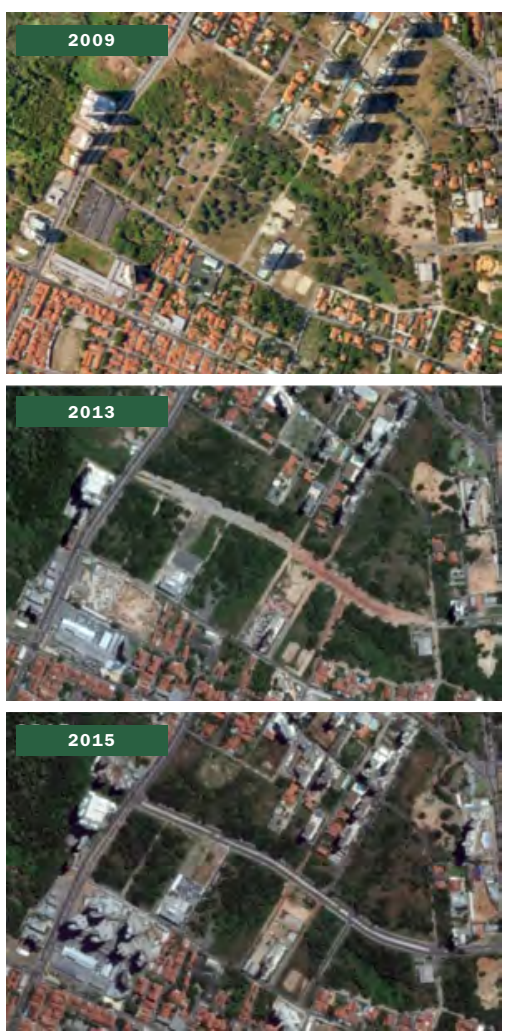

Fotos 38, 39 e $40 \mid$ Av. Chanceler Edson Queiroz (Fortaleza/CE). Área de APP completamente devastada para canalização de riacho e criação de avenida, viabilizando a exploração comercial de toda a gleba. Fonte: Google Earth. Acesso em 05 de março de 2016. 

nas áreas de ocorrência desses recursos hídricos que encontramos os territórios de ocupação mais difícil que, pelas restrições legais para construção, passaram a ser alvos de ocupações irregulares de todo tipo, independente de classe social. Desta feita, na mancha urbana de Fortaleza vemos diversos exemplos de ocupações clandestinas seja por uma população de baixíssima renda, com precárias construções de baixo padrão construtivo e carência de infraestrutura básica, seja pela classe média ou alta, com condomínios residenciais de alto padrão ou instalações de comércio e indústria.

Na medida em que os cursos hídricos constituíam entraves à exploração comercial ou acesso a terra urbana, eles passaram a ser intensivamente processados, adaptados ou até suprimidos da paisagem, cedendo espaço para vias e edificações. Vemos processos dessa natureza nos trechos mais densamente urbanizados da metrópole, nos quais já constatamos rios completamente tamponados ou transformados em simplórios canais de drenagem regularizados e pavimentados. A impermeabilização do solo e supressão da mata ciliar eliminaram drasticamente a biodiversidade local. Trechos que antes constituíam valiosos habitats para fauna e flora, hoje dá lugar a vias rodoviárias estéreis e desagradáveis. Nem ao bem estar do homem se presta.

As inúmeras lagoas que pontuam o desenho urbano de Fortaleza, por mais que façam parte de uma mesma bacia hidrográfica, cada vez mais se tornam ecologicamente desconectadas, segregadas pela mancha urbana que Ihes cercam, poluídas e constrangidas em suas margens, perdendo gradualmente sua capacidade de suporte de vida e resiliência às adversidades do meio. Somado aos prejuízos ecológicos constatamos os prejuízos funcionais dos canais de drenagem que cada vez mais se encontram sobrecarregados pelo aumento dos picos de escoamento, fruto da impermeabilização do solo da cidade, e pela perda de capacidade de vazão devido assoreamento acelerado dos leitos. 


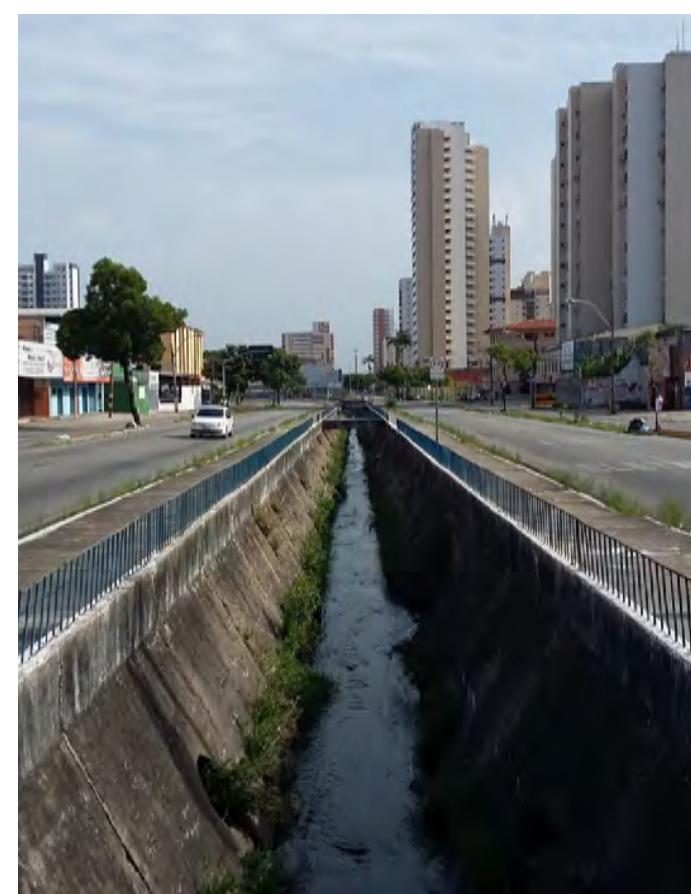

Foto 41 | Canal da avenida Aguanambi (Fortaleza/CE). Obra realizada na década de 1970 aterrou as margens do riacho e concretou seu leito para viabilizar a construção de uma vía expressa de entrada na cidade a partir da BR-116. Autor: Gerson Amaral - 2016.

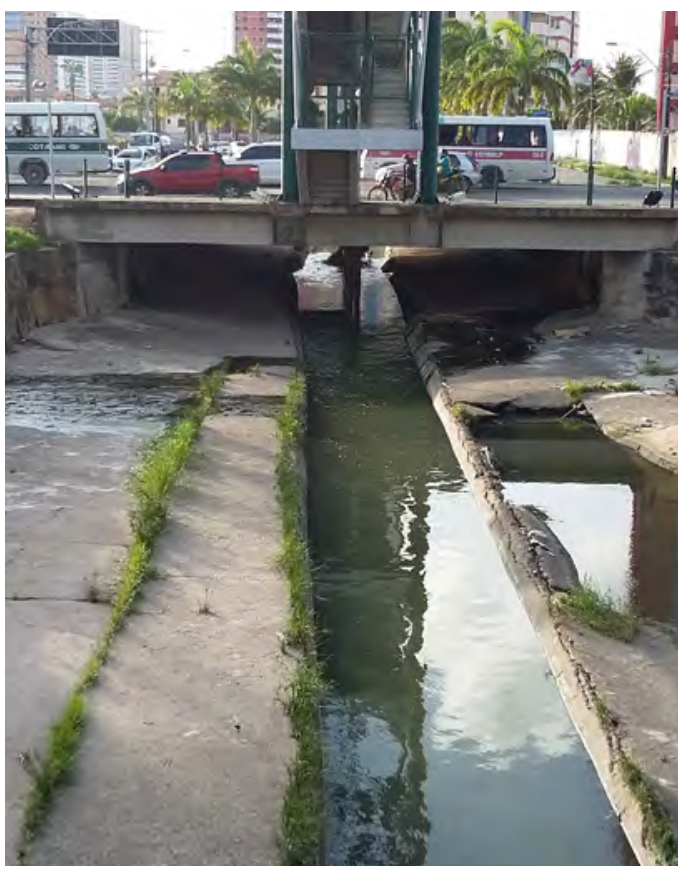

Foto 42 | Leito concretado do canal da avenida Eduardo Girão (Fortaleza/CE), em sua confluência com o canal da avenida Aguanambi. Autor: Gerson Amaral - 2016.

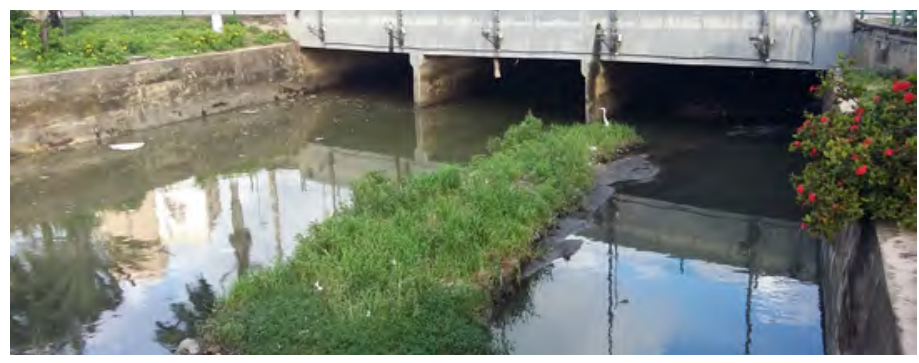

Figura 43 | Apesar da estratégias de aumento de velocidade do escoamento o assoreamento do canal persiste, fruto do grande volume de sedimentos e lixo carreados durante as chuvas. Local: Canal da Avenida Aguanambi (Fortaleza/CE). Autor: Gerson Amaral - 2016

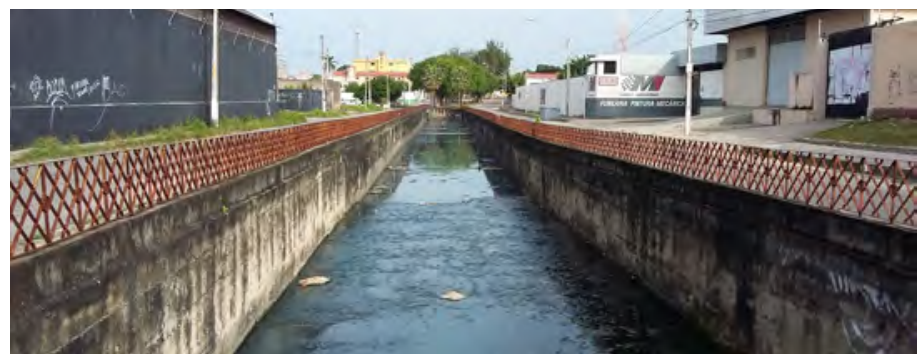

Foto 44 | Afluente do riacho Parreão (Fortaleza/CE) com leito concretado. Ao adquirir uma configuração tão artificial a população local passa a não identifica-lo mais como rio. Ligações clandestinas de esgoto são frequentes e o cheiro resultado reforça essa percepç̃o negativa. Autor: Gerson Amaral - 2016.

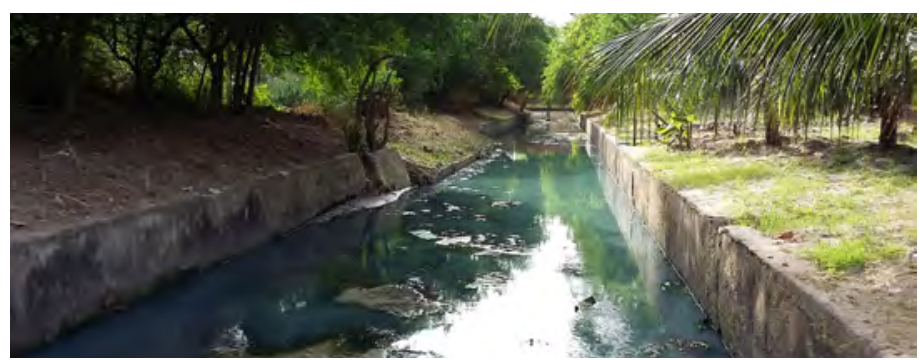

Foto 45 | Afluente do riacho Parreão (Fortaleza/CE) em trecho que corta propriedade privada. Muro de concreto segrega o rio da área verde circundante. Autor: Gerson Amaral - 2016

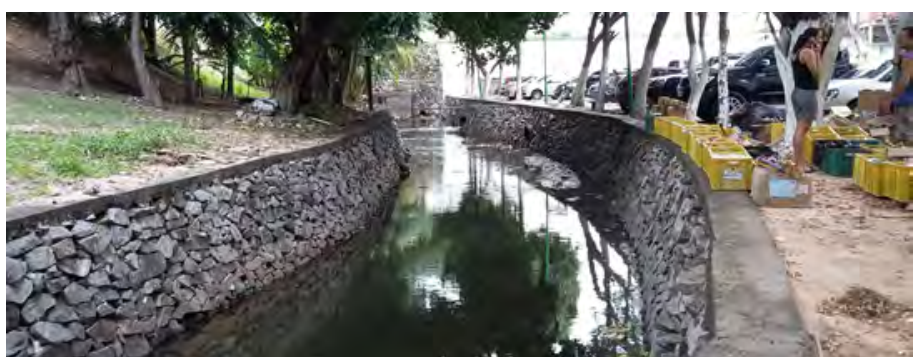

Foto 46 | O rio Pajeú (Fortaleza/CE) em trecho que corta o centro da cidade. A canalização em paredes de pedra argamassada foi utilizada nos poucos trechos em que ele ainda se encontra a céu aberto. Na foto vemos uma de suas margens utilizadas como estacionamento do Mercado Central. Autor: Gerson Amaral - 2016. 
Essa já é uma realidade de grande parte dos recursos hídricos da cidade de Fortaleza, contudo, ao analisarmos a globalidade dos rios que compõem a região metropolitana, encontramos uma ocupação relativamente menos densa que a região central do município de Fortaleza. Em contraste com a região central, em grande parte desse território encontramos ainda uma ampla conservação dos leitos naturais e planícies fluviais, na medida em que avançamos para a periferia dos aglomerados urbanos. Os rios e lagoas, portanto, ainda constituem fortes referenciais na paisagem da metrópole, muito embora em diferentes graus de degradação, poluição, assoreamento, devastação de mata ciliar e antropização do meio. Elas constituem importantes áreas verdes que, considerando sua estruturação no território, compõem grandes corredores verdes que permeiam a cidade, mesmo que ainda não sejam vistos em todo seu potencial urbanístico e ecológico. Apesar da degradação que já se manifesta, trata-se de uma situação ambiental que oferece ainda grandes possibilidades de recuperação da qualidade das águas, conservação e reintrodução da fauna e flora silvestres. Uma recuperação que se torna viável através de intervenções em trechos específicos, reestabelecendo a continuidade espacial dos biomas envolvidos e a preservação das áreas de proteção necessárias.

Dentro do desse quadro geral de degradação ambiental dos cursos hídricos, destacamos aqui dois notáveis exemplos que se diferenciam, apontando estratégias projetuais que apontam para uma melhoria na qualidade ambiental urbana de Fortaleza.

O primeiro trata-se de um pequeno porém notável exemplo de intervenção realizada em 1993 que tratou de um trecho do riacho Parreão, o qual aliou benefícios ecológicos à criação de um agradável espaço de lazer para a população local. 0 segundo exemplo constitui um dos maiores parques lineares da cidade, o Parque Rachel de Queiroz, ainda em processo de implantação, que está qualificando o que restou das margens do riacho Cachoeirinha. 


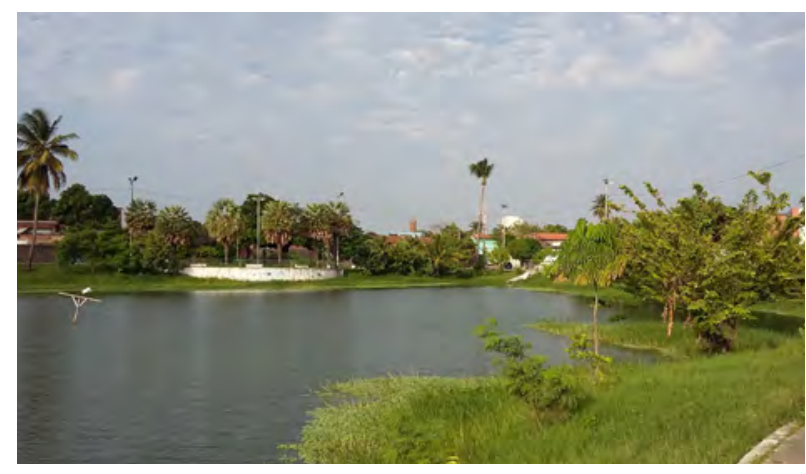

Foto 47 | Lagoa do Porangabussu (Fortaleza/CE). Apesar de todos os aterros e supressão de vegetação, a lagoa ainda se destaca como importante elemento natural na paisagem do bairro. Autor: Gerson Amaral - 2016.

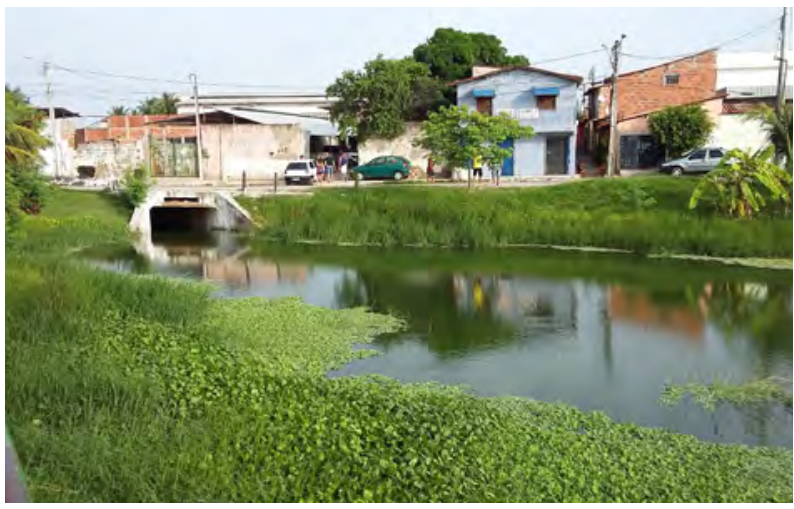

Foto 48 | Sangradouro da lagoa do Porangabussu. A partir desse ponto a água segue por canal de concreto. Autor: Gerson Amaral - 2016.

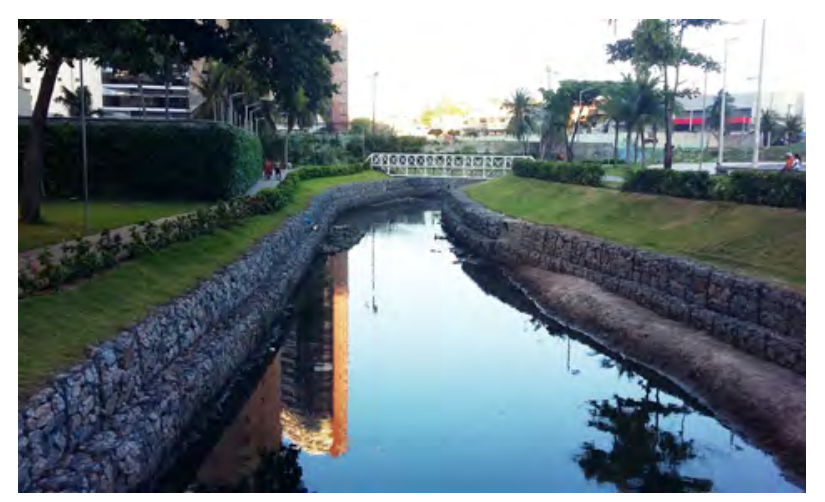

Foto 49 | Riacho Maceió (Fortaleza/CE) em trecho próximo a sua foz. Obra de canalização executada em 2014 utilizou gabião em suas paredes laterais. Apensar do menor impacto, a intervenção segue a mesma linha sanitarista. É notória a supressão da mata ciliar agora substituída por acanhado jardim de função meramente cosmética.

Autor: Gerson Amaral - 2016.

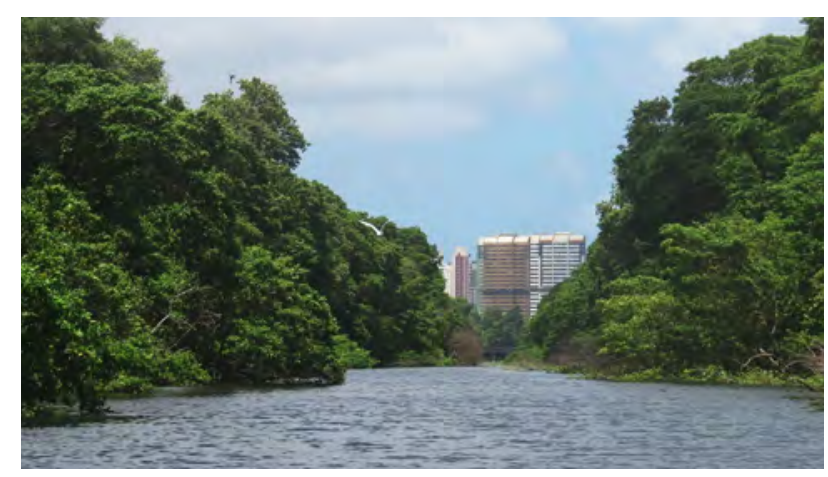

Foto 50 | Rio Cocó é componente da maior bacia hidrográfica do território de Fortaleza. O parque urbano que leva seu nome possui quilômetros de manguezais preservados e constitui um dos mais importantes recursos naturais da capital. Autor: Gerson Amaral - 2016.

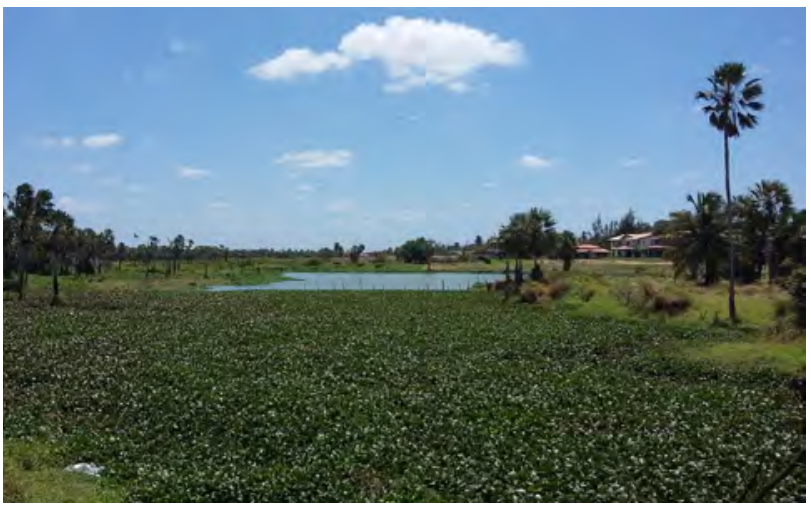

Foto 51 | Rio Coaçu em região próxima ao município de Eusébio/CE. Ainda é marcante a preservação da mata ciliar de carnaubeiras em sua ampla planície fluvial. Autor: Gerson Amaral - 2016. 


\section{Parque Parreão}

Construído em 1993, esse pequeno parque de $22.000 \mathrm{~m}^{2}$ foi concebido de forma a preservar a o leito natural do deste trecho do riacho optando por soluções construtivas de baixo impacto. Para proteção das margens foi utilizada apenas uma corda de pedras que, em certo trecho, passou a definir o leito maior do riacho, reservando uma ampla área verde para absorver o volume de transbordamento. 0 desenho sinuoso do leito menor foi preservado tanto quanto possível, e as áreas pavimentadas se limitaram a poucos percursos dispostos nos pontos mais altos do terreno. A solução de belo efeito estético e baixo custo criou um agradável espaço público, atrativo tanto para a população residente quanto para a fauna local pela ampla adoção de espécies vegetais nativas que hoje compõem rico bosque urbano.

Ao contrário da corriqueira solução de canal de concreto, que segrega o rio da paisagem, a preservação do leito maior do riacho assegurou a percepção deste recurso hídrico como importante componentes ecológico da paisagem. A permeabilidade, a sinuosidade e a rugosidade do leito são componentes fundamentais para a minimização da velocidade do escoamento superficial minimizando os efeitos dos alagamentos tanto na área do parque quanto a jusante. A definição de leito maior, claramente destinado para receber controladamente o transbordamento, revela a maturidade do desenho paisagístico no entendimento dos processos naturais que definem a paisagem que estava sendo construída. 


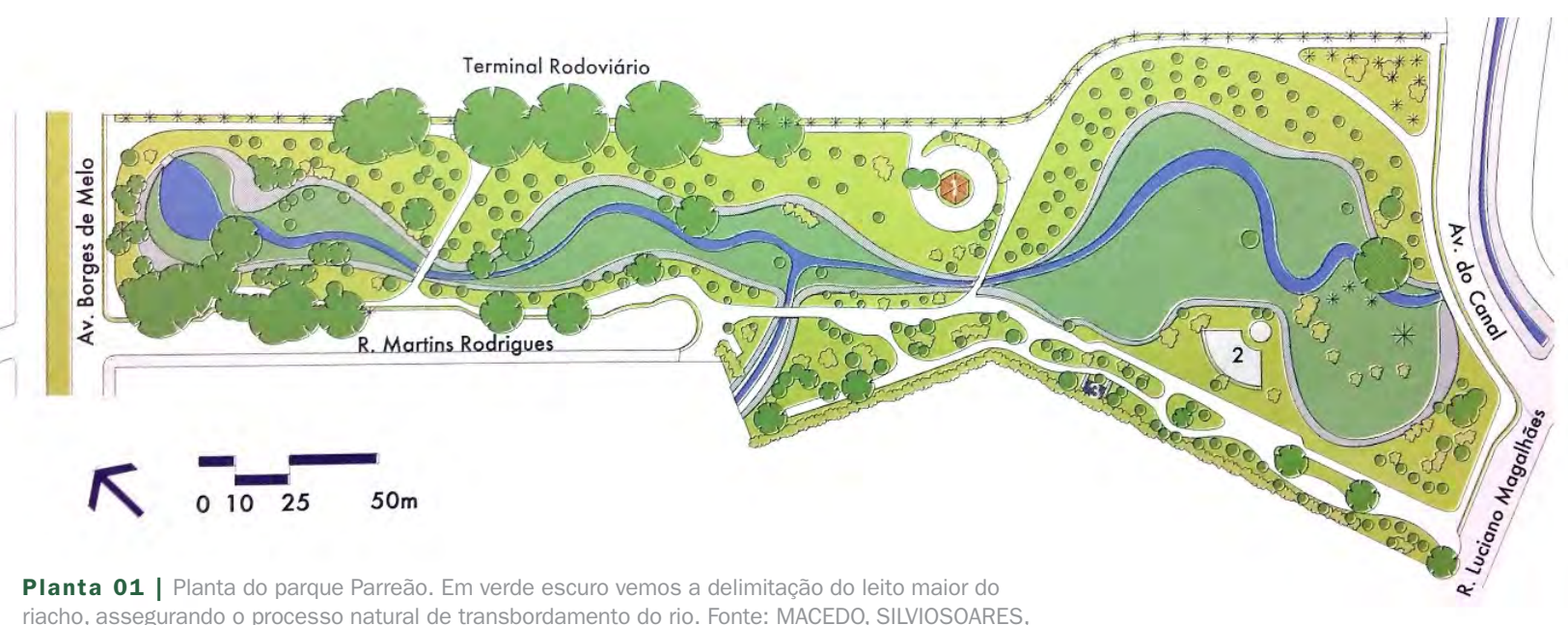

riacho, assegurando o processo natural de transbordamento do rio. Fonte: MACEDO, SILVIOSOARES, SAKATA, FRANCINE GRAMACHO. Parque urbano brasileiro. 2003. EDUSP. São Paulo.

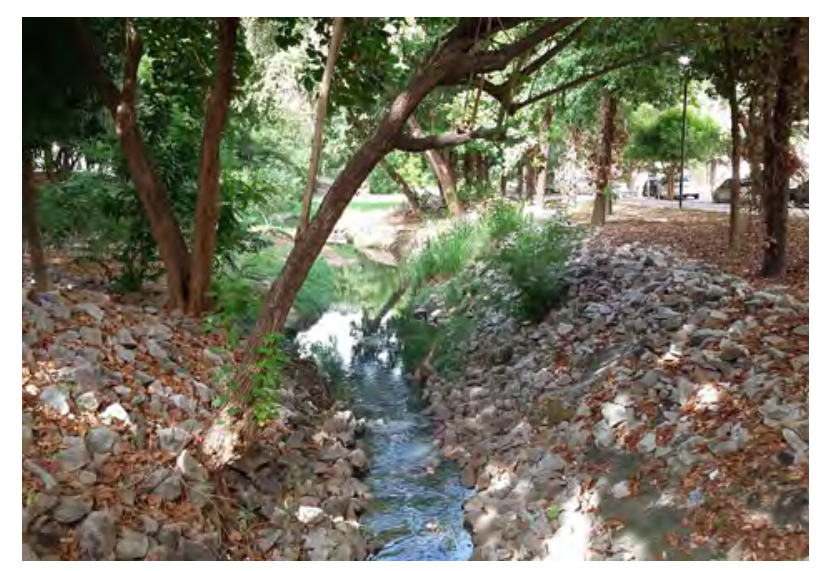

Foto 52 | Riacho Parreão no trecho que corta o parque. A contenção das margens utiliza corda de pedras soltas, conferindo um aspecto mais natural para o rio. Autor: Gerson Amaral - 2016.

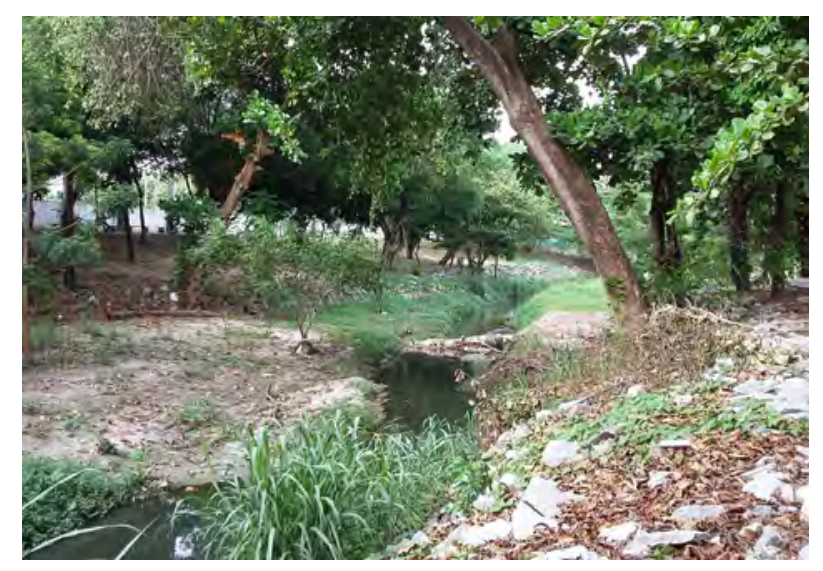

Foto $\mathbf{5 3}$ | Os processos erosivos naturais do rio não constituem problemas para a solução adotada. O leito menor do rio muda de configuração ao longo das estações sem qualquer dano para a integridade do parque. Autor: Gerson Amaral - 2016.

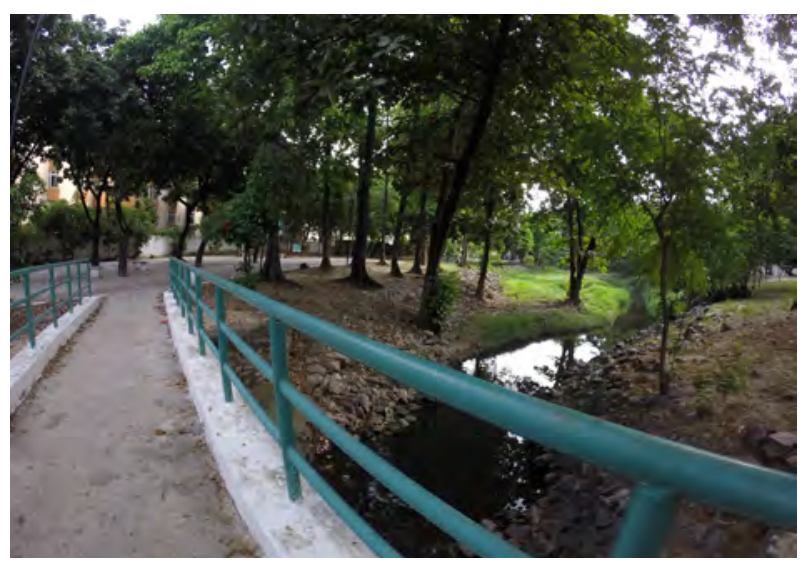

Foto 54 | Ponte sobre o rio acontece nos trechos mais estreitos do leito. Autor: Gerson Amaral - 2016

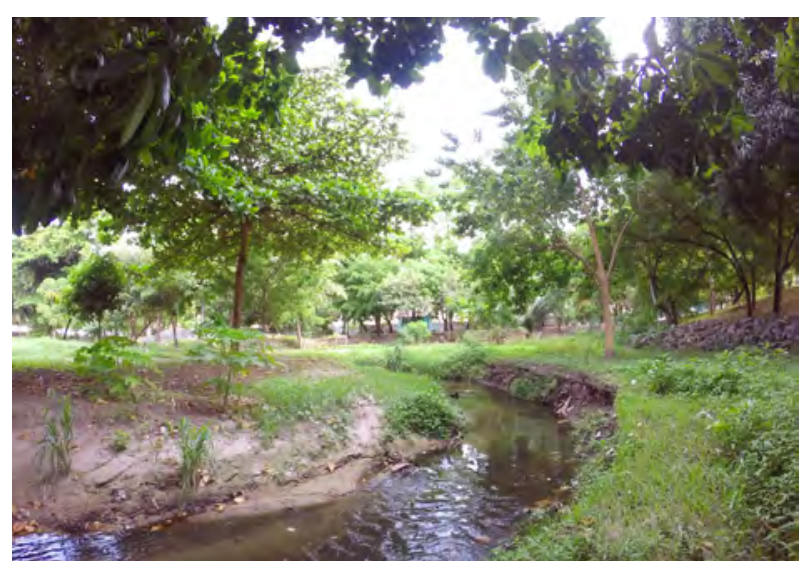

Foto 55 | Leito maior do riacho definido especialmente na porção sudeste do parque possui relevante papel na regulagem da vazão e promoção da infiltração no solo. Autor: Gerson Amaral - 2016. 
3.1.2

Parque Rachel de Queiroz

O parque é fruto de um movimento popular de atuação nos bairros na zona oeste de Fortaleza desde a década de 1980, visando benefícios à população e preservação do meio ambiente daquela área, já explorada pelas intervenções imobiliárias. Foi criado através do Decreto Municipal n 13.292, de 14 de janeiro de 2014 o qual considera que o parque:

\footnotetext{
“(...) se encontra em área verde da cidade configurada, pelo Plano Diretor Participativo (PDP-FOR/2009), na Macrozona de Proteção Ambiental, a qual é composta por ecossistemas de interesse ambiental, bem como por áreas destinadas a proteção, preservação, recuperação ambiental e ao desenvolvimento de usos e atividades sustentáveis, que se inicia no Açude João Lopes, Bairro Monte Castelo, nas proximidades das ruas Raquel Holanda e Gonçalo dos Lagos, seguindo até as margens do Rio Maranguapinho."
}

Sua área é de aproximadamente 203 hectares. Possui configuração linear, estruturando-se a partir de uma malha hidrográfica ao longo de aproximadamente $10 \mathrm{~km}$, desde o açude João Lopes até o desague junto ao rio Maranguapinho, cortando 15 bairros da zona oeste da cidade de Fortaleza.

Do projeto inicial de requalificação espacial do parque foram executados exclusivamente obras de drenagem que interviram no leito dos rios de forma a melhorar o condicionamento do escoamento fluvial em detrimento dos impactos ecológicos proporcionados por tais intervenções. Em suas primeiras obras, trechos de riachos tiveram suas margens retificadas, convertidas em um canal com piso e paredes de concreto. 0 resultado ecológico é desastroso, tendo em vista a incapaci- 

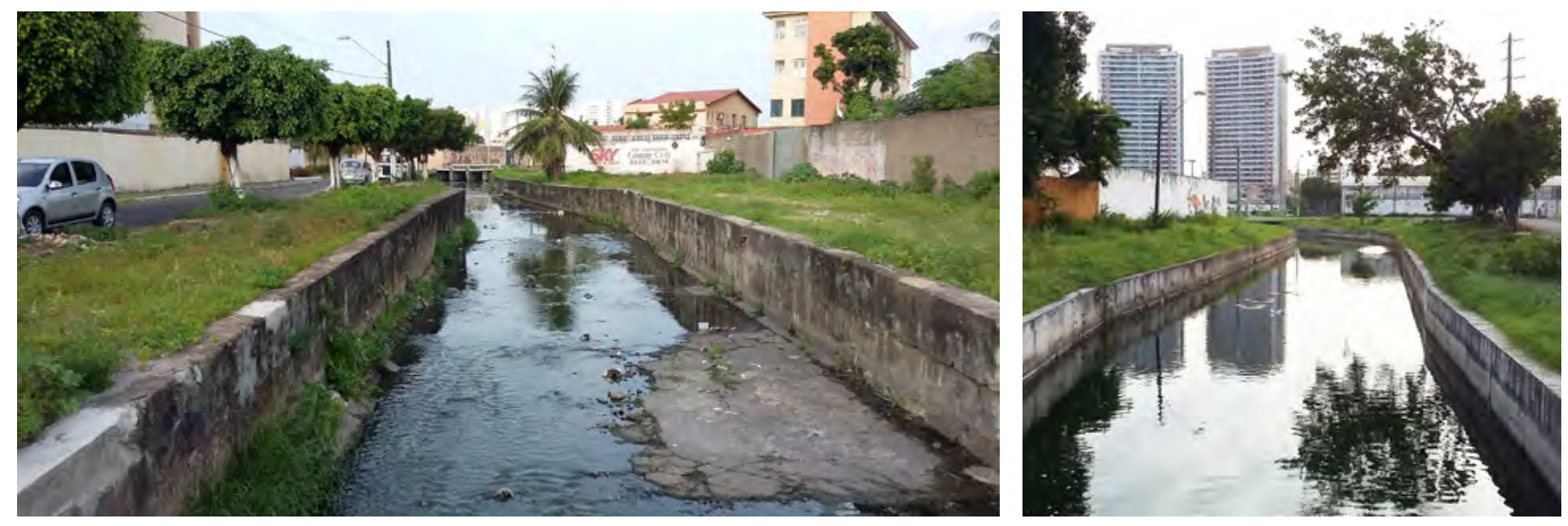

dade de estabelecimento de trocas biológicas entre o leito e suas margens. Além do desmatamento da mata ciliar, a elevação do nível das margens contida pelo arrimo do canal em concreto dificulta o acesso dos animais a água. A solução adotada tem como objetivo claro inviabilizar a capacidade de fixação da mata ciliar no leito do rio, aumentar a sua velocidade de escoamento e alargar a área útil das margens para implantação de sistema viário.

Os problemas de transbordamento, cada vez mais frequente, foram tratados de forma quantitativa, com altos custo ambientais como podemos observar na drástica intervenção realizada na área do Polo de Lazer Sargento Hermínio. O que era uma grande área alagável, com uma notável diversidade de espécies vegetais e habitat para grande número de animais, foi transformada em um imenso reservatório de água, construído para controlar o fluxo hídrico a jusante no caso de elevadas precipitações.

O espelho d'agua gerado foi geometricamente definido por muros de arrimo em concreto que viabilizou o aterro das margens para criação de um passeio pavimentado. A solução causa, além da drástica modificação das características ecológicas do terreno pela supressão de quase a totalidade da área verde do local, uma grave segregação do novo lago com as suas margens e a rarefeita arborização que foi poupada pela obra. 0 acesso de pessoas e animais também é dificultado e em alguns trechos, completamente inviabilizado dado o desnível criado.

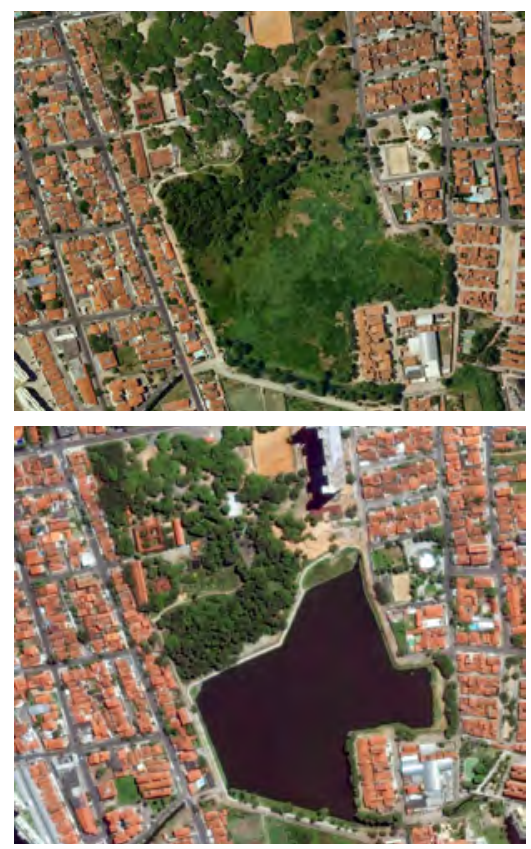

Figuras 58 e 59 | Maior obra hidráulica executada na primeira etapa de obras do parque criou imensa lagoa que ocupou quase a totalidade da área verde disponível. Fonte: Google Earth. Acesso em 05 de março de 2016. 


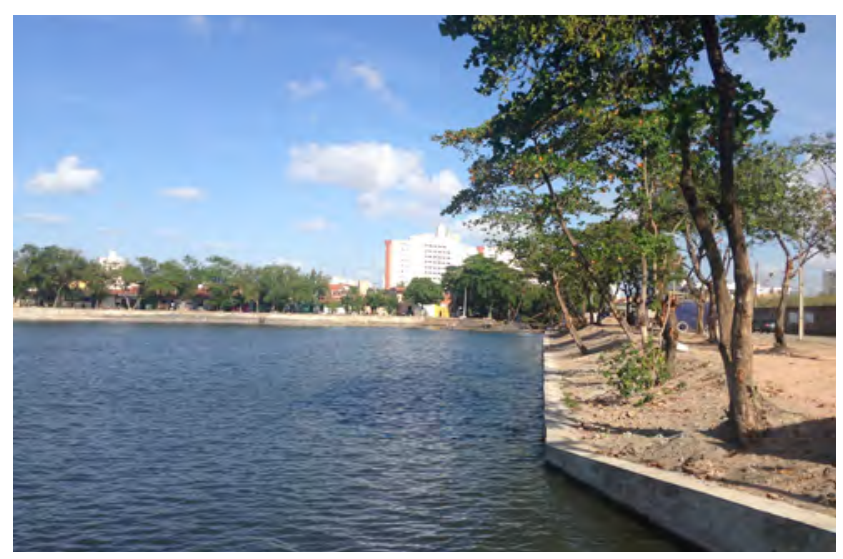

Foto 60 | Aspecto das margens em concreto que definem a lagoa criada. Autor: Iderlan Medeiros - 2014

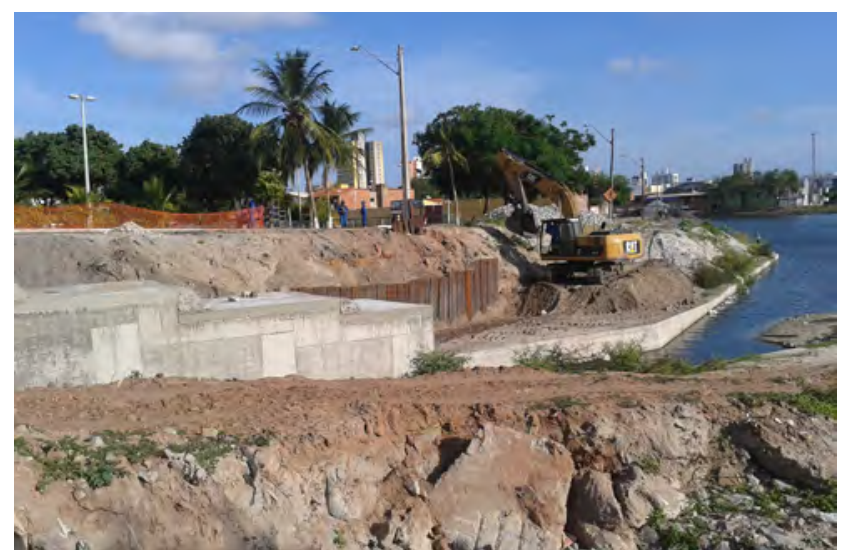

Foto 61 | Obras de aterro e concretagem das margens. Autor: Iderlan Medeiros - setembro de 2014.

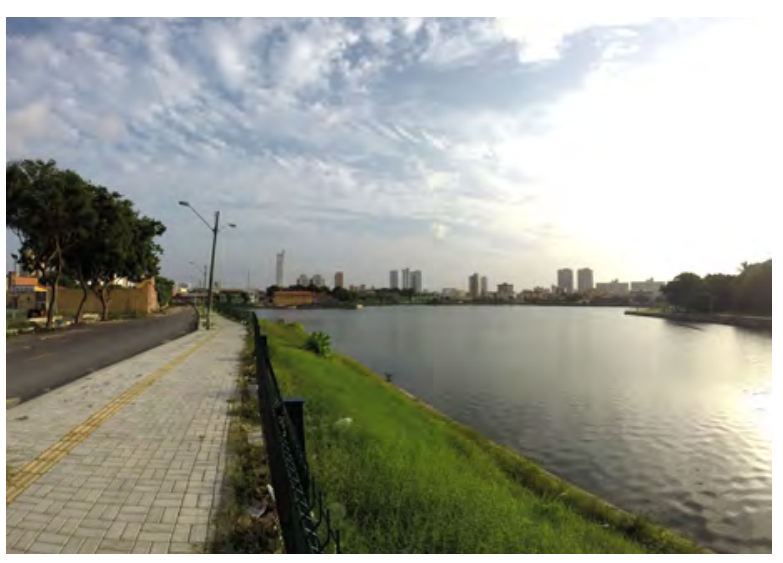

Foto 62 | Após construção da lagoa a área verde resultante se limita a estreita faixa gramada. Nem a arborização da calcada circundante foi proposta. Autor: Gerson Amaral - 2016.

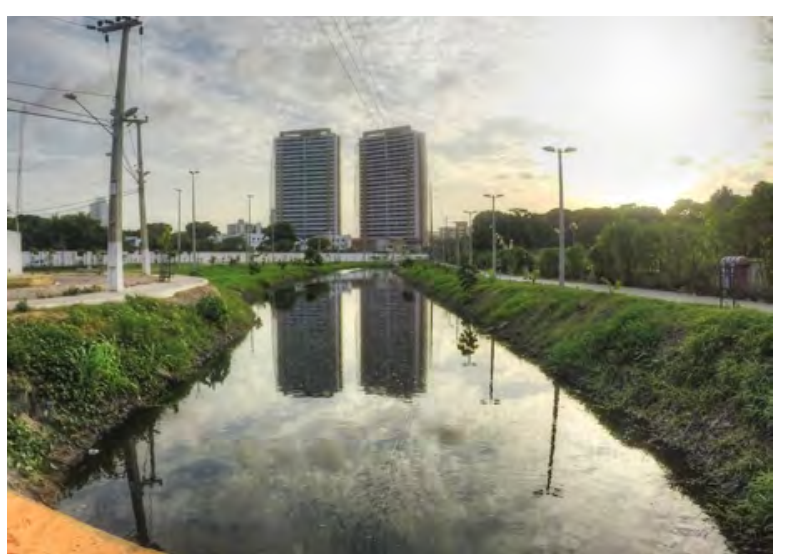

Foto 63 | Aspecto adquirido pelo riacho no trecho contemplado pela $2^{\mathrm{a}}$ etapa da intervenção. Por pressão dos movimentos sociais foi adotado o uso de gabião para as margens e colchão reno para o leito. 0 resultado final possui aspecto mais natural, assegurando a permeabilidade do solo e a fixação de vegetação. Autor: Gerson Amaral - 2016.

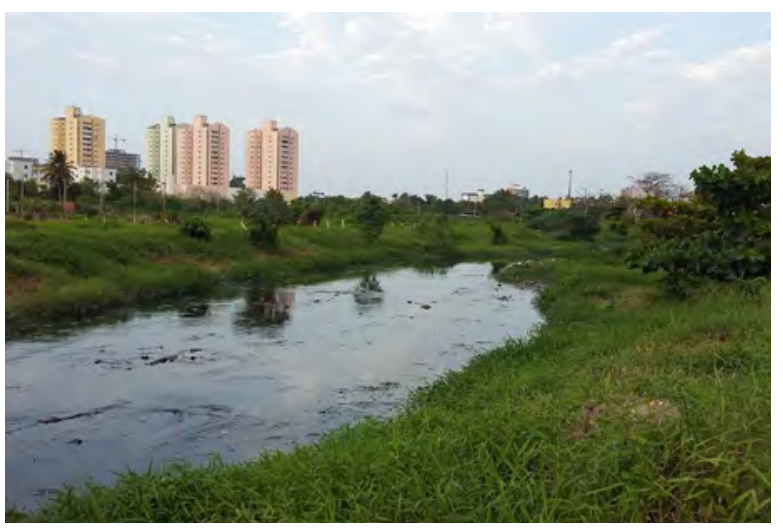

Foto 64 | Soluções de menor impacto permitiram uma melhor incorporação da natureza no resultado final. Mesmo sem a implantação do projeto paisagístico, a natureza se encarregou de reestabelecer o aspecto naturalizado do riacho, recobrindo as estruturas de pedra implantadas. Autor: Gerson Amaral - 2016 . 
De longe as obras de drenagem dessa primeira etapa de intervenção tiveram a preocupação com a preservação ou criação de um habitat natural, nem sequer a criação de áreas livres de lazer para a população. É notória, por exemplo, a exiguidade dos espaços destinados aos passeios na borda do espelho d'agua projetado.

A reação popular às soluções tradicionais de canalização do riacho tiveram força suficiente para gerar mudanças substanciais nas etapas subsequentes de implantação do parque. As intervenções que se seguiram na segunda etapa de intervenção adotaram algumas soluções menos impactantes como a construção do canal utilizando a técnica do colchão reno, o que traz uma melhoria substancial na permeabilidade do solo e redução da velocidade de escoamento do riacho. Da mesma forma se observa uma maior preocupação na arborização, mesmo que de forma incipiente. As margens taludadas asseguram o acesso da fauna ao leito do rio e permite a fixação de vegetação ripária, conferindo aspecto mais natural para rio.

Uma grande extensão do parque ainda espera por obras de qualificação urbana. Tais trechos ainda possuem grande potencial de tratamento adequado de suas áreas, preservando e qualificando as suas matas ciliares e incrementando as funções ecológicas de seus alagadiços e planícies fluviais que remanescem em alguns trechos.

Essa mudança de postura verificadas nas distintas etapas de implantação do Parque Rachel de Queiroz apontam para um crescente interesse, por parte dos setores públicos, na preservação dos cursos hídricos, pela adoção de um discurso ambientalmente sustentável e preservação de áreas verdes de suas margens, muito embora esse processo de amadurecimento esteja sendo algo tardio e lento, enfrentando grandes dificuldades para instrumentação e capacitação do corpo técnico envolvido e conscientização da população local sobre os valores ambientais do rios urbanos.

A questão ambiental na região vem recebendo um grande impulso nas áreas de projeto através da busca cada vez mais frequente de selos ambientais tais como LEED, Aqua, Procel, entre outros. Seja no setor privado, seja no setor público, vimos surgir obras que buscam adotar boas práticas de construção com o objetivo de serem contempladas com os respectivos selos ambientais como prova de uma preocupação tanto com o meio ambiente quanto com uma maior qualidade na concepção dos espaços construídos. Tal é o estudo de caso que será analisado na sequência: o projeto para construção do Campus da Fiocruz no Ceará. 


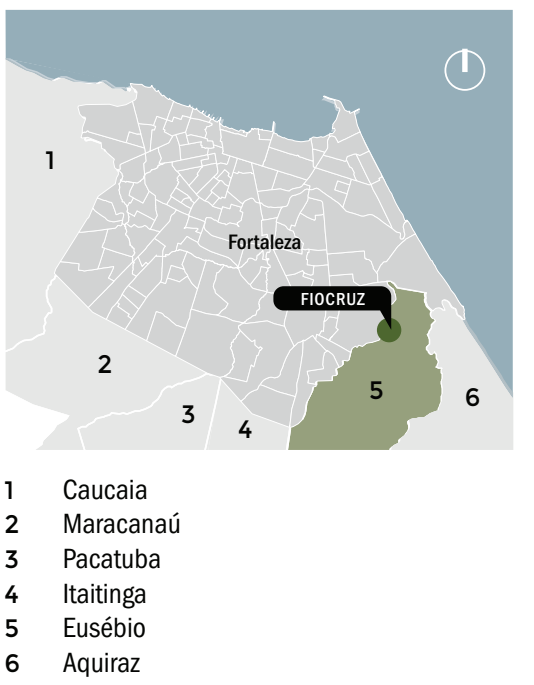

Mapa 03 | Localização do campus da Fiocruz dentro da Região Metropolitana de Fortaleza. Elaborado pelo autor.

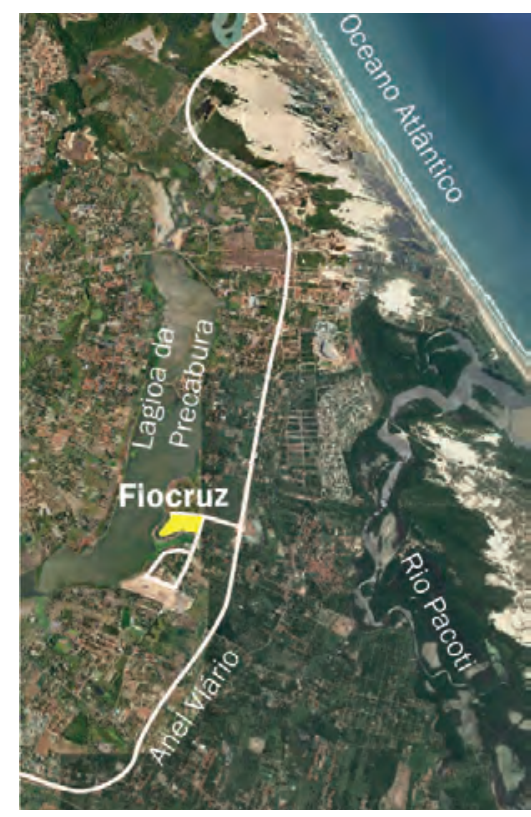

Mapa 04 | Localização do Campus da Fiocruz junto a lagoa da Precabura. Fonte: Elaborado pelo autor sobre imagem do Google Earth.

\section{2}

\section{Projeto para o Campus da Fiocruz no Ceará}

Localizado no município de Eusébio, na região metropolitana de Fortaleza, o campus da Fiocruz no Ceará ocupa um terreno localizado junto à lagoa da Precabura. A Fiocruz é o equipamento pioneiro do Polo Industrial e Tecnológico da Saúde (PITS), criado em 2012, que tem como objetivo principal desenvolver o segmento farmoquímico do Estado, promover a inovação e a integração entre a academia e o setor privado e fomentar a sinergia entre as indústrias que formam o Polo. 0 polo ocupará uma área de aproximadamente 30 hectares e terá três empresas âncoras: Fundação Oswaldo Cruz (Fiocruz), Centro de Tecnologia da Informação Renato Archer (vinculado ao Ministério da Ciência e Tecnologia) e Isofarma Industrial Farmacêutica Ltda.

O pólo se instalará em região de grande crescimento urbano, já em processo avançado de conurbação com a cidade de Fortaleza, mas que ainda preserva amplas áreas verdes, especialmente no entorno da Lagoa da Precabura, e na planície fluvio marinha do rio Pacoti. Uma expansão do anel viário encontra-se em fase de implantação e garantirá o acesso ao complexo através da ampliação da rua São José, conectando-o a pontos estratégicos como o Porto do Mucuripe, BR-116 e CE-040.

A Fiocruz ocupará um terreno de $103.683,83 \mathrm{~m}^{2}$, porém, em sua primeira fase de implantação, a instituição efetivamente ocupará $57.000 \mathrm{~m}^{2}$ e contará com um bloco de Laboratórios e Pesquisa, um prédio de Gestão e Ensino, um auditório, praça central com dois quiosques, o prédio de Infraestrutura e Serviços, guaritas e estacionamentos.

Na implantação do empreendimento a Fiocruz identificou uma oportunidade de incorporar a todo o processo de construção, operação e manutenção da instituição novas práticas de responsabilidade ambiental, tomando partido de melhores práticas de construção e as mais eficientes tecnologias que assegurem o menor impacto do empreendimento sobre o meio ambiente onde se implanta. 0 objetivo é que o empreendimento torne-se exemplo de sustentabilidade como forma de disseminar valores e impulsionar esta prática no cenário local evidenciando as suas vantagens.

Como metodologia para alcance destes objetivos, a Fiocruz optou pela adoção de uma certificação Ambiental para o empreendimento, o qual, desde as primeiras fases de projeto, estabeleceu critérios para avaliação do desempenho do edifício frente aos vários aspectos ambientais relacionados. 

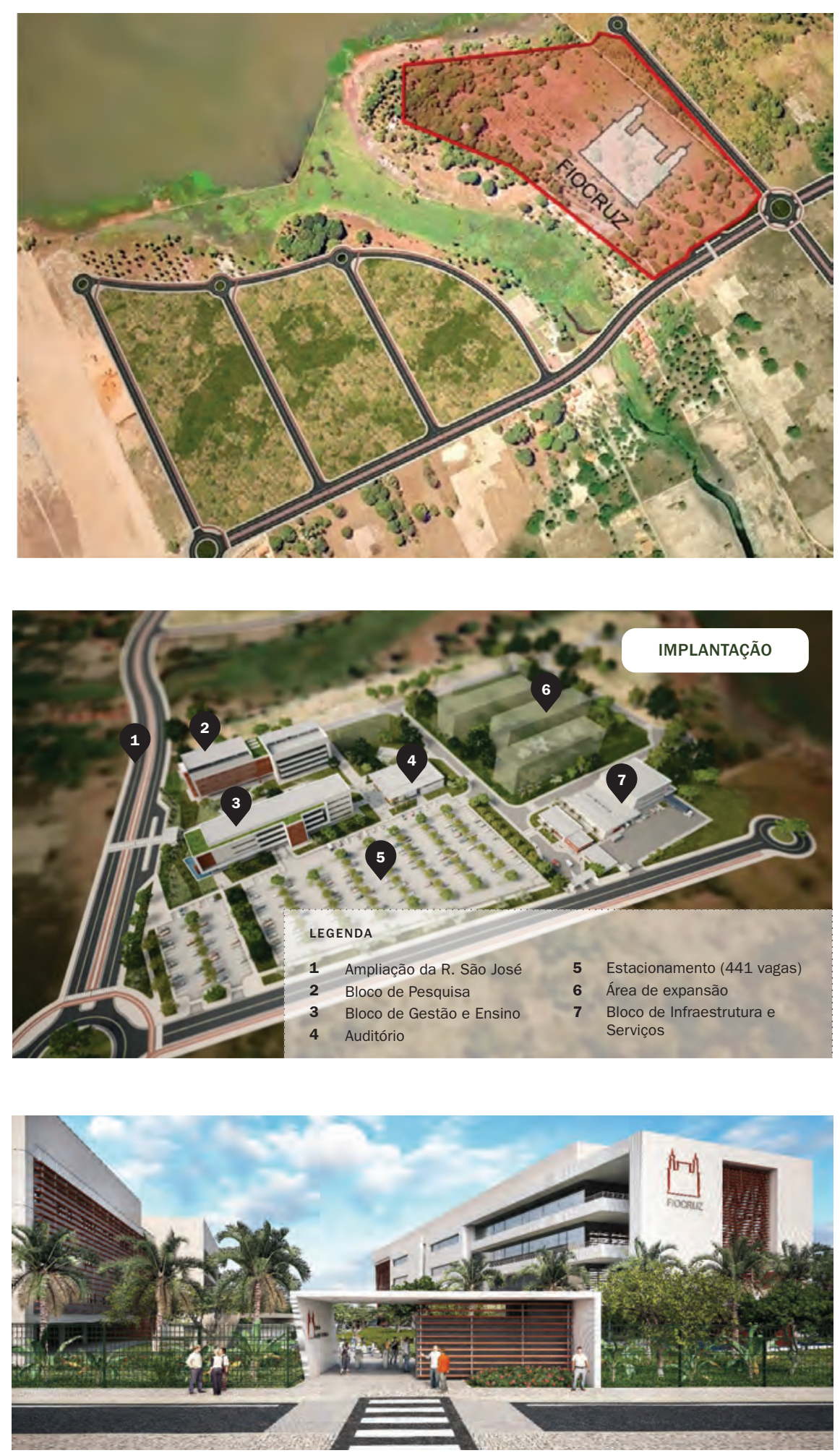

Desenho 07 | Terreno da Fiocruz no contexto do Pólo Industrial e Tecnológico da Saúde. Podemos ver a relação com a lagoa a oeste e o córrego em sua latera sul. Fonte: Memorial Descritivo do Projeto Executivo de Arquitetura Fiocruz Unidade Ceará. Architectus S/S.

Desenho 08 | Visão geral do campus da Fiocruz Ceará em sua primeira fase de implantação. Fonte: ARCHITECTUS.

Memorial Descritivo do Projeto Executivo de Arquitetura Fiocruz Unidade Ceará.

Desenho 09 | Imagem digital do acesso principal ao campus da Fiocruz Ceará. Edifício de Gestão e Ensino em. destaque a direita. Fonte: ARCHITECTUS. Memorial Descritivo do Projeto Executivo de Arquitetura Fiocruz Unidade Ceará. 


\section{3}

\section{Certificação ambiental na construção civil}

O ramo da construção civil tem incorporado cada vez mais em seus planos o tema da sustentabilidade na sua produção. Isso é consequência de mudanças na forma de concepção, planejamento, gestão e manutenção de empreendimentos, com o objetivo de torna-los mais sustentáveis. 0 compromisso ambiental tem exigido o planejamento no desenvolvimento dos projetos e obras, a formalização e o aperfeiçoamento técnico de materiais e sistemas construtivos, a inovação tecnológica, a racionalização do processo produtivo, a preservação de recursos naturais, a responsabilidade social e, especialmente, a consolidação de um ambiente construído mais saudável e confortável.

O que caracteriza um empreendimento sustentável não são apenas soluções de consumo racional de recursos, eficiência energética, gestão de resíduos e baixa emissão de gases de efeito estufa. O sustentável também aborda a qualidade de vida dos usuários e a permanência dos desempenhos ao longo do tempo, considerando também a inserção urbana, seus impactos sobre a vizinhança, a relação com o entorno e as questões econômicas operacionais e imobiliárias envolvidas.

O empreendimento sustentável parte da boa arquitetura, que promove o convívio harmonioso entre as pessoas em um ambiente saudável, confortável e de baixo impacto ambiental.

Para o alcance desses objetivos, foi necessário o estabelecimento de critérios e condições, de ordem técnica e legal, para determinar se este ou aquele produto e processo de produção, atendem a nomenclatura dos princípios éticos e de produção inseridos no conceito de sustentabilidade, ora estabelecido pela sociedade moderna, o qual chamamos de "certificação".

Os chamados processos certificadores seguem instrumentos regulatórios estabelecidos por entidades ou governos, os quais se utilizam os profissionais, empresas e produtores, para informar a sociedade se determinado produto, modelo de produção, atende os requisitos indispensáveis para considerá-lo política e ambientalmente correto. No Brasil, utilizam- 
se como referência regulatória os ditames da Lei nº 6938/81 (Lei do Meio Ambiente), Código Florestal, e outras legislações nacionais e internacionais.

Além disso, integram os processos de certificações ambientais Selos ou ISOs, a elaboração de sistemas de gestão ambiental, auditorias ambientais, avaliações de desempenho, selos ambientais, rotulagem ambiental, entre outros mecanismos, inerentes ao sistema de produção, de produtos ou serviços, objeto da certificação.

As ditas "Ecoetiquetas", que se constituem em Selos e ISOs, asseguram a melhoria da qualidade ambiental dos produtos, gerando vantagens para os consumidores, produtores e, claro, para o meio ambiente, tais como: aumenta a consciência dos consumidores e produtores; incrementa a venda e agrega valor ao produto certificado; gera informação exata sobre a qualidade do produto e seu sistema de produção; protege o meio ambiente; auxilia no aprimoramento dos processos de produção, obrigando os produtores à adoção de medidas que diminuam os impactos ambientais adversos, entre outros.

As certificações precisam ser renovadas e reavaliadas periodicamente por um órgão regulador certificador, que será responsável pela credibilidade dos métodos de avaliação do certificado. O certificador pode tanto ser um órgão público, quanto uma empresa privada independente, a exemplo da ISO - INTERNATIONAL ORGANIZATION FOR STANDARTIZATION, que no geral, possuem como atribuição, promover a harmonização e o desenvolvimento de normas para produtos, processos e sistema de gestão ambientais.

Posto isso, denota-se que as Certificações Ambientais são ferramentas fundamentais para a sustentabilidade do meio ambiente, especialmente no contexto da construção civil, para assegurar que os sistemas de produção, produtos e serviços, estejam comprometidos com uma performance econômica e ambiental corretas, na busca de uma vida digna e saudável 
e que preserve o meio ambiente onde vivemos, com vistas a garantir, entre outros benefícios, um consumo sadio e de qualidade, o uso racional e responsável dos recursos materiais do planeta, garantindo a sobrevivência das gerações futuras.

Dentre os inúmeros benefícios resultantes de empreendimentos sustentáveis podemos elencar:

- Economia direta no consumo de água e energia;

- Menores despesas gerais como limpeza, conservação e manutenção;

- Menor demanda sobre as infraestruturas urbanas;

- Redução considerável da poluição;

- Redução das emissões de Gases de Efeito Estufa;

- Menor impacto à vizinhança;

- Menor demanda de recursos hídricos;

- Melhores condições de conforto e saúde para seus usuários;

- Valorização patrimonial ao longo do tempo

- Melhor aproveitamento da infraestrutura local;

- Melhor gestão de riscos;

- Melhor gestão de resíduos sólidos;

- Consciência de sua contribuição para o desenvolvimento sustentável e a sobrevivência no planeta.

O Brasil possui diversas certificadoras que atendem a produtos e ramos específicos de produção e serviços. Dentre aqueles vinculados ao ramo da construção civil podemos citar o ISSO 1401 (conferida pela Associação de Normas Técnicas -ABNT), o selo LEED (conferido pelo Green Building Council), Procel (Programa Nacional de Conservação de Energia Elétrica) e Processo AQUA (conferida pela Fundação Vanzolini). 
Para a Certificação Ambiental do Campus da Fiocruz Ceará foi escolhido o Processo AQUA, o qual é a adaptação para o Brasil da "Démarche HQE", da França e contém os requisitos para o Sistema de Gestão do Empreendimento (SGE) e os critérios de desempenho nas categorias da Qualidade Ambiental do Edifício (QAE).

Nesse processo, para obter a certificação o empreendedor da construção deve estabelecer o controle total do empreendimento em todas as suas fases:

- Programa;

- Concepção (Projeto);

- Realização (Obra) e

- Operação (Uso)

Isso deve ser realizado por meio do Sistema de Gestão do Empreendimento (SGE), para que sejam atendidos os critérios de desempenho da Qualidade Ambiental do Edifício (QAE). Os requisitos do SGE exigem o comprometimento com o perfil de QAE visado e acompanhamento, análise e avaliação da QAE ao longo do empreendimento, entre outros. Os critérios de desempenho do QAE abordam a eco-construção, a eco-gestão e a criação de condições de conforto e saúde para o usuário. (Fundação Vanzolini, 2007)

Todo o processo conta com 14 categorias ou objetivos distribuídos em quatro bases de ação: ecoconstrução, ecogestão, conforto e saúde. 0 empreendedor é pontuado por três níveis de desempenho: excelente, superior e bom. Para obter a certificação deve alcançar pelo menos três níveis "excelente" e quatro "superior".

O Campus possui certificação ambiental nas suas diversas etapas: programa, concepção e realização, e dentro do processo AQUA foi aplicado o Referencial Técnico de Edifícios de Setor de Serviços: Escritórios - Edifícios Escolares (Versão 0 de 15/10/2007). 
Tal como citado anteriormente, o processo AQUA divide-se em duas etapas:

- O referencial do Sistema de Gestão do Empreendimento (SGE) serve para avaliar o sistema de gestão ambiental implementado pelo empreendedor, nesse caso a FIOCRUZ.

- O referencial da Qualidade Ambiental do Edifício (QAE) serve para avaliar o desempenho arquitetônico e técnico da construção.

A Qualidade Ambiental do Edifício (QAE) divide-se em 14 categorias que refletem as considerações ambientais. Estas categorias são desmembradas em subcategorias, que representam as principais preocupações associadas a cada consideração ambiental, e que por sua vez se dividem em preocupações elementares. (Fundação Vanzolini, 2007)

Dentre as diversas categorias, a presente pesquisa terá maior foco na categoria n5: Gestão da água, sem deixar de considerar também o rebatimento que as soluções de drenagem e paisagismo trarão para outras categorias, tais como: Relação do Edifício com Seu entorno, Escolha integrada de produtos, sistemas e processos construtivos, Gestão de Energia, Manutenção, Conforto Visual, Conforto Olfativo e Qualidade Sanitária do Ar.

Em seu referencial técnico, o processo AQUA destaca na Gestão da Água, dentre outros quesitos, que a "gestão de águas pluviais no terreno possibilita uma ação em escala micro urbana que visa limitar o escoamento de águas pluviais a fim de prevenir o risco de inundação e reduzir a poluição difusa". (Fundação Vanzolini, 2007)

Para atingir esse objetivo foram assumidas opções de intervenção em três parâmetros:

- A RETENÇÃO: reter a água após a chuva a fim de assegurar um escoamento controlado quer no meio natural quer no sistema de drenagem;

- A INFILTRAÇÃO: favorecer a percolação de águas pluviais nos solos a fim de manter tanto quanto possível o ciclo da água; 
- O TRATAMENTO: recuperar as águas que escoaram sobre superfícies com risco de poluição (estacionamento, zonas de circulação de veículos, etc.) e tratá-las em função da sua natureza antes do descarte.

O quadro de avaliação do SGE assim avalia essas intervenções e seus critérios de avaliação:

\begin{tabular}{|c|c|c|c|}
\hline \multirow{2}{*}{ PREOCUPAÇÃO } & \multirow{2}{*}{ INDICADOR } & \multicolumn{2}{|c|}{ CRITÉRIO DE AVALIAÇÃO } \\
\hline & & (TÍTULO) & (NÍVEL) \\
\hline \multirow{2}{*}{$\begin{array}{l}5.2 .1 \\
\text { Gestão da } \\
\text { retenção }\end{array}$} & \multirow{2}{*}{$\begin{array}{l}\text { Vazão de escoa- } \\
\text { mento após a } \\
\text { implantação do } \\
\text { sistema projetado }\end{array}$} & $\begin{array}{l}\text { Inferior ou igual à } \\
\text { vazão inicial }\end{array}$ & Bom \\
\hline & & $\begin{array}{l}\text { Inferior ou igual } \\
\text { à vazão inicial e } \\
\text { Inferior à vazão de } \\
\text { escoamento que } \\
\text { corresponde a uma } \\
\text { impermeabilização } \\
\text { de } 65 \% \text { da superfí- } \\
\text { cie do terreno }\end{array}$ & Excelente \\
\hline \multirow{6}{*}{$\begin{array}{l}5.2 .2 \\
\text { Gestão da } \\
\text { infiltração }\end{array}$} & \multirow{3}{*}{$\begin{array}{l}\text { Coeficiente de } \\
\text { impermeabilização } \\
\text { após a implantação } \\
\text { do sistema projetado }\end{array}$} & $70 \%$ a $80 \%$ & Bom \\
\hline & & $60 \%$ a $70 \%$ & Superior \\
\hline & & $<60 \%$ & Excelente \\
\hline & \multirow{3}{*}{$\begin{array}{l}\text { Para os locais forte- } \\
\text { mente urbanizados: } \\
\text { percentagem de } \\
\text { melhoria do coefi- } \\
\text { ciente de impermea- } \\
\text { bilização do estado } \\
\text { existente }\end{array}$} & $<2 \%$ & Bom \\
\hline & & $2 \%$ a $10 \%$ & Superior \\
\hline & & $>10 \%$ & Excelente \\
\hline $\begin{array}{l}5.2 .3 \\
\text { Gestão de } \\
\text { águas de } \\
\text { escoamento } \\
\text { poluídas }\end{array}$ & $\begin{array}{l}\text { Recuperação e } \\
\text { tratamento de águas } \\
\text { de escoamento } \\
\text { poluídas }\end{array}$ & $\begin{array}{l}\text { Medidas tomadas } \\
\text { para recuperar as } \\
\text { águas de escoa- } \\
\text { mento potencial- } \\
\text { mente poluídas } \\
\text { e para tratá-las } \\
\text { antes do descarte } \\
\text { em função da sua } \\
\text { natureza }\end{array}$ & Bom \\
\hline
\end{tabular}

Tabela 01 | Fonte: Adaptado de FUNDAÇÃO VANZOLINI, 2007, p. 110. 
O tema das águas pluviais também é avaliado na categoria 01 - Relação do Edifício com o seu entorno. Neste quesito, o quadro de avaliação da categoria destaca:

\begin{tabular}{|c|c|c|}
\hline PREOCUPAÇÃO & INDICADOR & $\begin{array}{c}\text { CRITÉRIO } \\
\text { DE AVALIAÇÃO }\end{array}$ \\
\hline $\begin{array}{l}1.1 .4 \\
\text { Prevenir o risco } \\
\text { de inundação nas } \\
\text { áreas suscetíveis } \\
\text { e limitar a } \\
\text { propagação de } \\
\text { poluentes }\end{array}$ & $\begin{array}{l}\text { Ações para limitar } \\
\text { o escoamento das } \\
\text { águas pluviais }\end{array}$ & 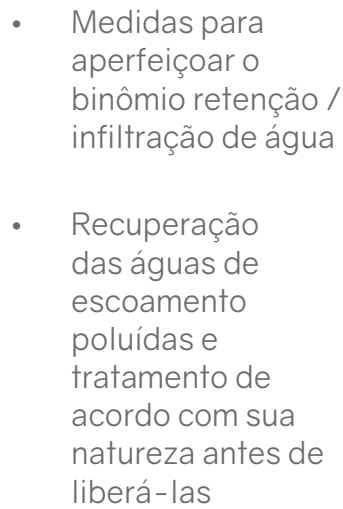 \\
\hline
\end{tabular}

Tabela 02 |Fonte: Adaptado de FUNDAÇÃO VANZOLINI, 2007, p. 46.

Adicionalmente, o referencial técnico cita como exemplos de elementos para a otimização do binômio retenção / infiltração:

- Conhecimento dos dados pluviométricos e do solo;

- Sistemas de infiltração específicos implantados (poço aberto, lameiros, charcos, açudes);

- Sistemas de retenção implantados (telhados verdes, poços, cisternas, espelhos d'água etc.);

- Coeficiente de impermeabilização;

- Gestão da retenção.

Foram consideradas questões como características regionais, orçamento, programa em desenvolvimento, viabilidade das tecnologias, entre outras para que possam ser aplicadas as diretrizes mais viáveis para o edifício em questão. 
De acordo com o Perfil Ambiental do Empreendimento, ilustrado a seguir, foi proposto o nível máximo de qualidade para a categoria Gestão da Água, o que exigiu o mais alto nível de desempenho técnico para as soluções infraestruturais que possuem qualquer relação com o tema, tanto dentro do perímetro do empreendimento, como seu impacto para os corpos hídricos ao seu redor, resultando nos seguintes níveis de avaliação:

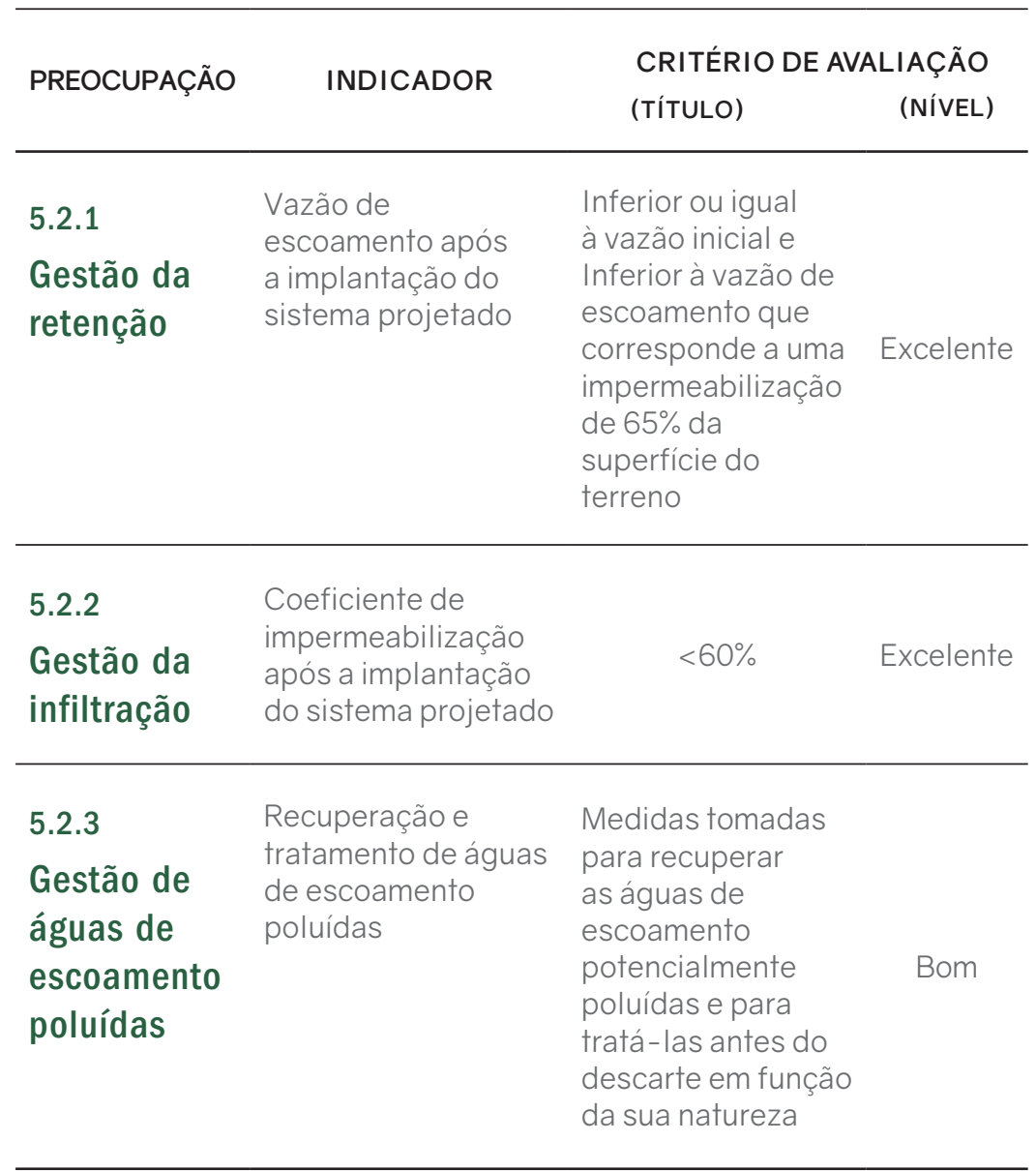

Tabela 03 | Níveis de avaliação - Gestão da Água. 


\section{PERFIL AMBIENTAL DO EMPREENDIMENTO}

\section{EXCELENTE}

\section{SUPERIOR}

\section{BOM}

\section{ECO - CONSTRUÇÃO}

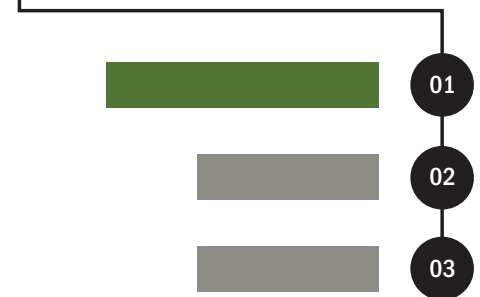

Relação do edifício com seu entorno

Escolha integrada de produtos, sistemas e processos construtivos

03 Canteiro de obras com baixo impacto ambiental

\section{ECO - GESTÃO}

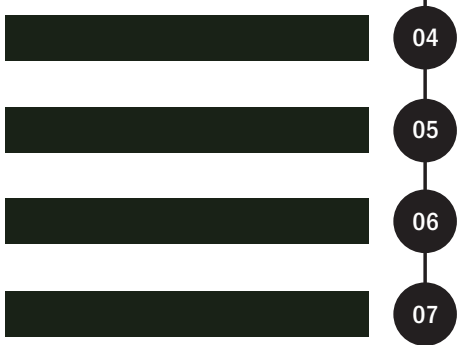

Gestão de energia

Gestão da água

Gestão dos resíduos de usos e operação do edifício

Manutenção - Permanência do desempenho ambiental

\section{CONFORTO}

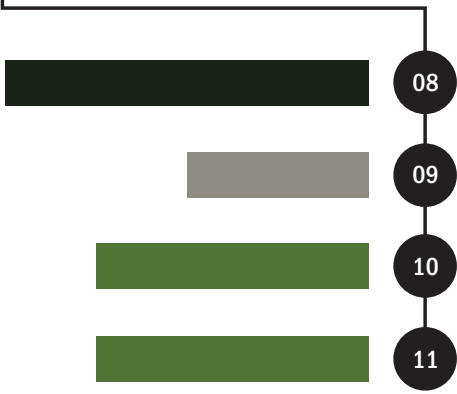

Gestão de energia

Gestão da água

Gestão dos resíduos de usos e operação do edifício

Manutenção - Permanência do desempenho ambiental

\section{SAÚDE}

Qualidade sanitária dos ambientes

Qualidade sanitária do ar

Qualidade sanitária da água 


\section{4}

\section{0 projeto de drenagem}

O sistema de drenagem urbana aqui analisado contempla exclusivamente a drenagem das áreas livres do campus. Não são consideradas as contribuições das águas pluviais das cobertas dos edifícios visto que essas serão conduzidas através de um sistema de captação, tratamento e reuso dessas águas para uso no próprio edifício, assim como para rega das áreas ajardinadas.

O controle preciso da condução das águas pluviais do campus é possível em virtude das configurações do relevo do local, o qual assegura que não haja contribuições externas ao terreno, além das características da instituição que será responsável pela manutenção do sistema de forma independente da drenagem do entorno.

A primeira ação para definição das soluções técnicas de drenagem urbana que atendessem criteriosamente aos três itens exigidos (retenção, infiltração e tratamento) tem relação direta com o projeto de implantação do campus e definição de seu arruamento.

A implantação do campus já foi algo previamente determinado pela equipe técnica da Fiocruz, determinando o arruamento, o posicionamento dos edifícios e a definição da área de expansão, inviabilizando maiores ajustes em sua conformação. 0 desenho posto teve a preocupação de evitar a ocupação das áreas próximas à lagoa da Precabura e porção do território com maior densidade de vegetação (setor sudoeste do terreno). O desenho ortogonal adotado para o arruamento acontece alheio à forma da gleba e à morfologia do terreno, impactando fortemente no resultado do escoamento superficial das águas pluviais e, consequentemente no projeto de drenagem, como será mostrado na sequência.

A escolha dos diferentes materiais componentes da pavimentação do campus foi orientada para minimizar, tanto quanto possível, a impermeabilização do solo. Considerando as diferentes características de uso, exigências de fluxo e carga, foram adotados pisos com características drenantes seja nos passeios, seja em parte do sistema viário. Dessa forma, em toda a pavimentação externa dedicada aos pedestres foi utilizada uma placa drenante de concreto pré-moldado $(50 \times 50 \mathrm{~cm})$ sob leito de areia. Por sua vez, nas vagas para carros de todos os estacionamentos foi utilizado piso ecológico pré-moldado de concreto e grama. Ambas soluções, se considerada a extensão de sua aplicação no campus, tem grande impacto na promoção da absorção no solo, reduzindo significativamente o escoamento superficial.

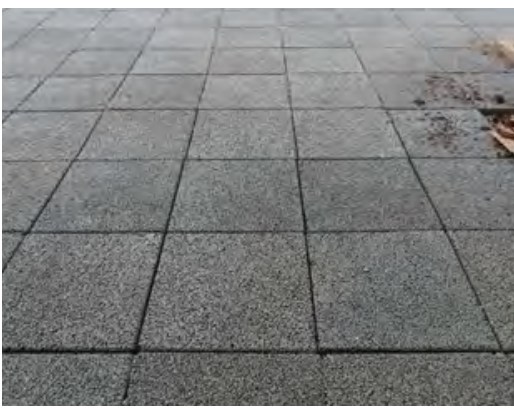

Foto 65 | Pavimentação dos passeios e praças do campus sendo executadas em placas drenantes. Fotos da obra em março/2016. Autor: Gerson Amaral.

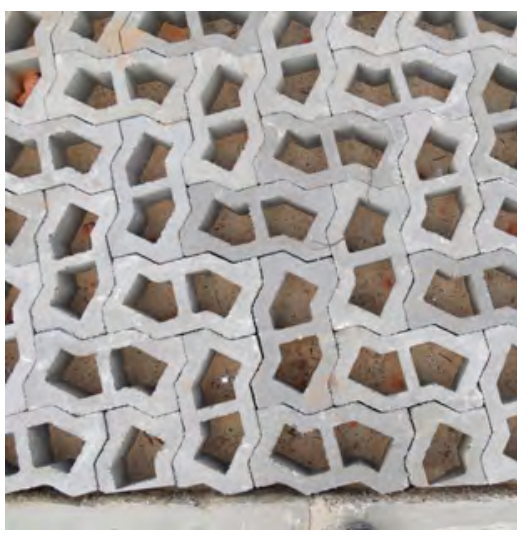

Foto 66 | Piso ecológico adotado para as vagas de estacionamento do campus. Fotos da obra em março/2016. Autor: Gerson Amaral.

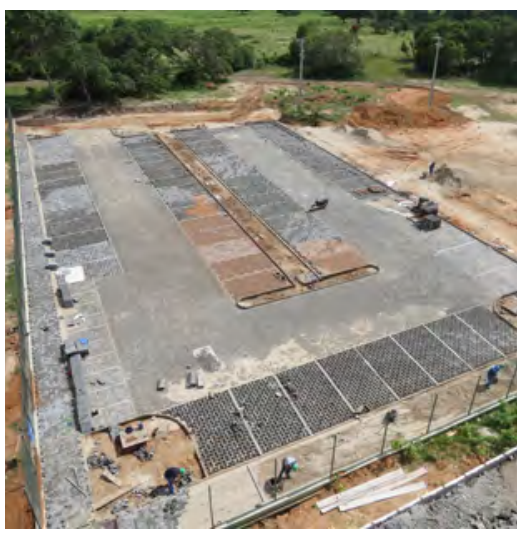

Foto 67 | Configuração da pavimentacão do estacionamento de visitantes. Circulação em piso intertravado pré-moldado de concreto e vagas pavimentadas com piso ecológico. Fotos da obra em março/2016. Autor: Gerson Amaral. 
0 projeto de terraplanagem, também em atenção às diretrizes da certificação ambiental, definiu os níveis de fundação dos diferentes blocos e níveis das áreas livres adaptando-os às configurações naturais do relevo, em trabalho de terraplanagem que compensou os volumes de corte e aterro. 0 terreno, de pouca inclinação, possui caimentos nos sentidos sul e oeste, possuindo cota mais elevada em seu vértice nordeste, onde se localiza o maior bolsão de estacionamento. Essa configuração determinou o escoamento superficial das áreas pavimentadas, principalmente do sistema viário, direcionado majoritariamente no sentido sul e oeste, conforme podemos verificar na planta 02 .

Considerando essas bases de arruamento e implantação do campus, foram iniciados os estudos para o desenvolvimento do projeto de drenagem, o qual, a princípio, não possuía nenhum condicionante específico além dos parâmetros postos pela certificação ambiental.

Uma solução tradicional de drenagem facilmente optaria pelo lançamento direto do volume escoado através de dois vertedouros, um junto ao cul-de-sac a oeste, lançando as águas diretamente para a lagoa, e outro ao sul do terreno, diretamente para o riacho limítrofe. Essa opção foi inicialmente descartada em virtude da necessidade de tratamento prévio da carga poluidora carreada pelo escoamento superficial antes do descarte nos recursos hídricos.

Diante disso, a solução adotada contou com a criação de um sistema de captação e condução subterrânea das águas pluviais para um sistema de tratamento composto por um filtro vortex localizado no limite sul do terreno, que seria responsável pelo tratamento de todo o volume escoado antes do seu descarte no riacho.

Considerando os picos de escoamento superficial durante os eventos de precipitação, o projeto previu uma cisterna para detenção do volume escoado de forma a controlar a vazão de entrada no filtro vortex, tendo em vista sua capacidade máxima de tratamento. A concepção preliminar do sistema de drenagem das águas pluviais pode ser sintetizada pelo esquema que segue.

A adoção do filtro vortex consegue dar uma resposta adequada para o tratamento das águas, cumprindo com as exigências do item 5.2.3. Gestão de águas de escoamento poluídas do SGE. A cisterna que precede o filtro vortex detém o volume escoado com vistas ao controle da vazão de entrada, considerando sua capacidade de tratamento. Para tanto, foi dado início ao cálculo do dimensionamento do sistema.

Importante salientar que nesta solução foi ignorada a necessidade de promoção da infiltração no solo conforme exigia o SGE. Nessa fase de projeto, como se constata, não havia qualquer discussão sobre o uso de tecnologias de baixo impacto para as soluções de drenagem. Apenas o piso drenante e piso ecológico constituíam soluções que apontava nessa direção. 

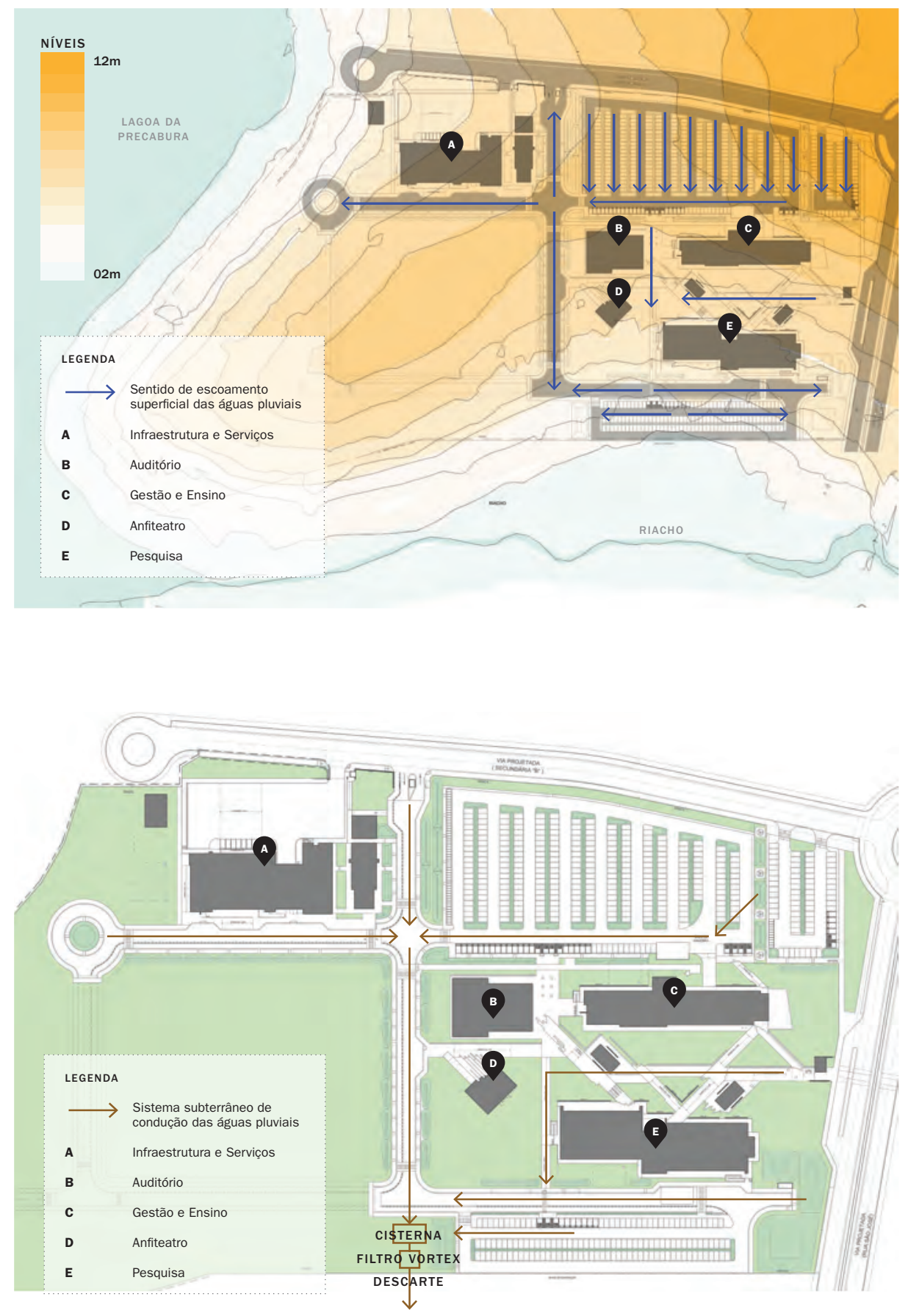

Planta 02 | Configuração do relevo condicionou o caimento das vias do campus. A terraplanagem optou pela mínima intervenção, promovendo uma compensação de cortes e aterros na definição dos patamares de assentamento das diferentes edificaçōes. Planta elaborada pelo autor com base nos estudos iniciais fornecido pela ARCHITECTUS S/S
Planta 03 | Síntese do esquema de condução subterrânea das águas pluviais elaborado no estudo preliminar. Planta elaborada pelo autor com base nos estudos iniciais fornecido pela ARCHITECTUS.
Gráfico 06 | Esquema de condução das águas pluviais idealizado na fase de anteprojeto. Autor: Gerson Amaral. 


\subsection{1}

Dimensionamento do sistema

Estabelecido o esquema geral do sistema de drenagem, foi dado início ao dimensionamento da infraestrutura com base no cálculo do volume de escoamento resultante após a implantação do empreendimento em função das características pluviométricas da região.

Conforme memorial descritivo do Projeto de Drenagem Pluvial, a intensidade das chuvas foi calculada através da equação das chuvas intensas, $i=\left(K \times T^{a}\right) /(t+b)^{c}$, onde $T$ é o tempo de retorno em anos e $t$ a duração da chuva em minutos.

Os valores de "k", "a", "b" e "c" foram obtidos através do software Pluvio 2.1. Para tempo de retorno $(T)$ considerou-se 10 anos e para duração 60 minutos.

A partir dos dados acima obtivemos:

\begin{tabular}{ccccccc}
\hline$*$ Intensidade das chuvas $[i=(\mathrm{K} \times \mathrm{Ta}) /(\dagger+\mathrm{b}) \mathrm{c}]$ & & \\
\hline $\begin{array}{c}\text { RETORNO } \\
\begin{array}{c}\text { EM ANOS } \\
(\mathrm{T})\end{array}\end{array}$ & $\begin{array}{c}\text { DU- } \\
\text { RAÇÃO } \\
(\mathrm{T})\end{array}$ & $\mathrm{K}$ & A & B & C & $\begin{array}{c}\text { INTENS. } \\
(\mathbf{M M} / \mathrm{H})\end{array}$ \\
\hline 10 & 60 & 491,78 & 0,21 & 5,00 & 0,64 & 55,15 \\
\hline
\end{tabular}

Tabela 04 | Cálculo de intensidade das chuvas.

Desta feita, estimando-se um tempo de recorrência de 10 anos, a maior intensidade de chuva observada na região metropolitana de Fortaleza foi de 55,15 milímetros por hora. Sobre esse volume total de precipitação foi feito um cálculo de vazão inicial do terreno, considerando as suas características de solo e ocupação. 
Foi utilizado o método racional conforme descrito a seguir.

\begin{tabular}{|c|c|c|c|c|c|}
\hline \multirow[t]{2}{*}{$\begin{array}{l}\text { TIPO DE } \\
\text { SUPERF. }\end{array}$} & \multirow[t]{2}{*}{$\begin{array}{c}\text { C. E.S.* } \\
\text { (C) }\end{array}$} & \multirow[t]{2}{*}{$\begin{array}{l}\text { INTENSIDADE } \\
\text { PLUVIOMÉTRICA } \\
\text { (I) - L/H.S }\end{array}$} & \multirow[t]{2}{*}{$\begin{array}{l}\text { ÁREA DE } \\
\text { CONTRIB. } \\
\text { (A) - HA }\end{array}$} & \multicolumn{2}{|c|}{$\begin{array}{c}\text { VAZÃO DE } \\
\text { ESCOAMENTO } \\
(\mathrm{Q})\end{array}$} \\
\hline & & & & $\mathrm{L} / \mathrm{I}$ & $\mathrm{M}^{3} / \mathrm{H}$ \\
\hline $\begin{array}{l}\text { Terrenos } \\
\text { livres e } \\
\text { ajardina- } \\
\text { dos (solo } \\
\text { pesado) }\end{array}$ & 0,05 & 153,18 & 6,00 & 45,95 & 165,44 \\
\hline
\end{tabular}

Tabela 05 | *C.E.S.: Coeficiente de Escoamento Superficial

Chegou-se, portanto, ao volume máximo de escoamento superficial do terreno diante do maior evento pluviométrico em um período de retorno de 10 anos $\left(165,44 \mathrm{~m}^{3} / \mathrm{h}\right)$. Determinase, pois que, de acordo com as determinações do SGE, esse volume escoado deve permanecer inalterado, ou até ser reduzido após a implantação do campus.

Considerando a impermeabilização do solo prevista e o consequente aumento do coeficiente de runoff do local, o excedente de escoamento superficial produzido quando da implantação do empreendimento deverá ser detida em algum ponto do sistema antes de ser tratada para descarte no riacho. Para melhor dimensionamento desse excedente, o campus foi dividido em seis diferentes bacias conforme topografia do terreno e urbanização prevista em projeto. A partir dos dados definidos, calculou-se a vazão projetada em cada uma das bacias de modo a dimensionar o que seria necessário para atingir os objetivos da certificação. Assim foram obtidos os seguintes valores: 


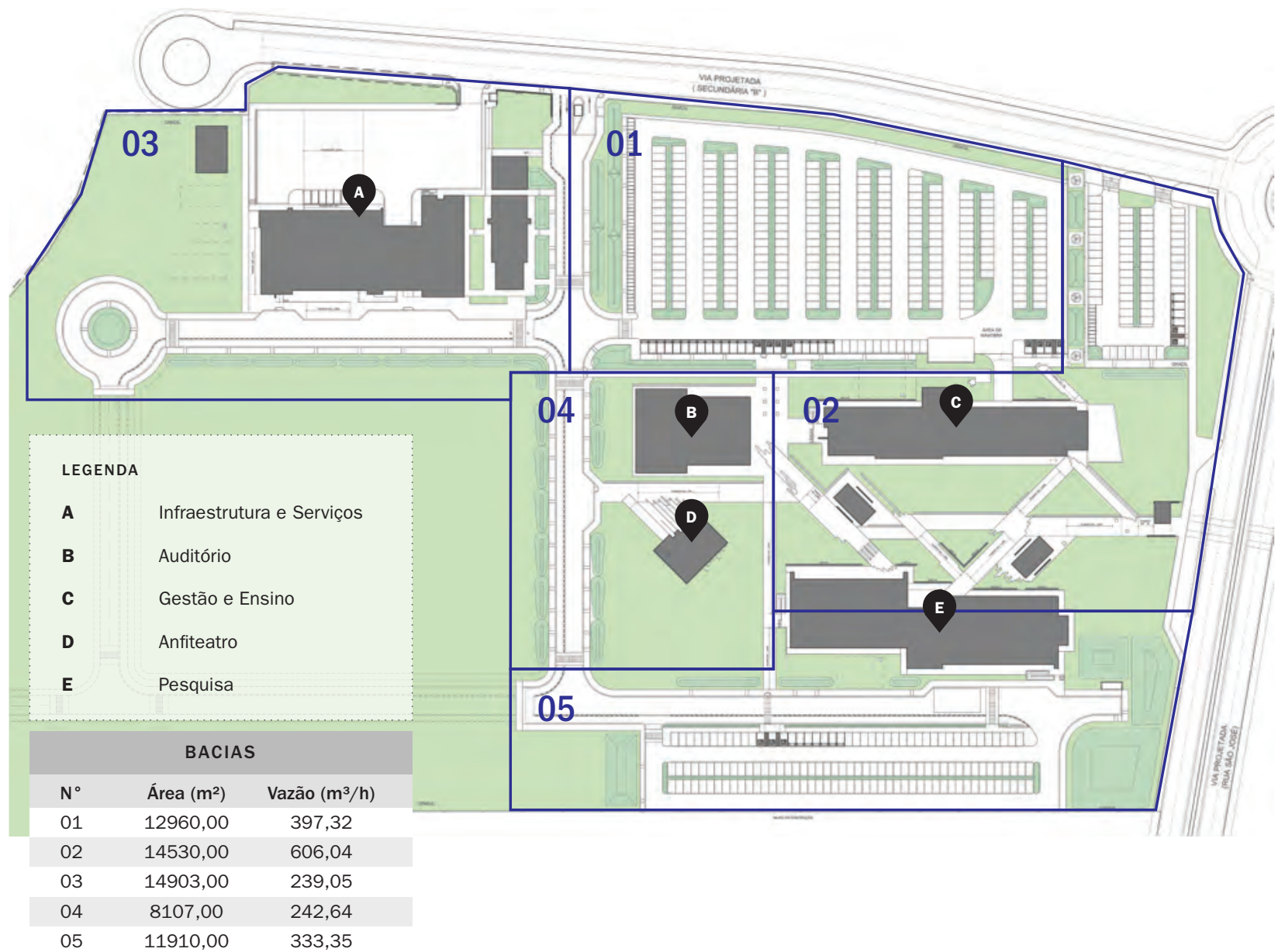

Percebe-se, portanto, o aumento substancial da vazão de es-

Planta 04 | Subdivisão da área do campus em 5 bacias para cálculo das vazões finais de escoamento (runoff). Planta elaborada pelo autor com base nos estudos fornecido pela ARCHITECTUS S/S. coamento superficial previsto após a implantação do campus. De uma vazão de escoamento original de $165,44 \mathrm{~m}^{3} / \mathrm{h}$, passamos a ter um total de $1818,40 \mathrm{~m}^{3} / \mathrm{h}$, o que equivale a um aumento de mais de $1000 \%$ na vazão de escoamento.

O grande volume obtido trouxe grandes desafios para o esquema de drenagem originalmente concebido. Para o dimensionamento adotado, compatível para o porte do empreendimento, o filtro vortex proposto não tem capacidade suficiente de tratamento das águas pluviais nas precipitações de maior intensidade. Da mesma forma, o uso de uma cisterna convencional para armazenamento temporário do pico de vazão tornou-se inviável, dada as dimensões desproporcionais que tal equipamento teria que adquirir dentro do conjunto como um todo, resultando em um impasse técnico diante do desafio que se descortinava. Além disso, restava insolúvel a questão da promoção da infiltração das águas pluviais no solo. 


\section{5}

\section{Infraestruturas verdes: uma solução possível}

As infraestruturas cinzas inicialmente concebidas para o sistema de drenagem do campus não conseguiram dar uma resposta viável para as determinações da certificação ambiental, a qual preza pela mitigação das alterações causadas pela implantação do campus no ciclo hidrológico local através do controle da poluição difusa, retenção das águas e promoção de sua infiltração no solo.

A equipe técnica de engenharia que estava envolvida no projeto até então desconhecia as soluções de baixo impacto para resolução de sistemas de drenagem. 0 projeto paisagístico foi o responsável pela proposição do uso de jardins de chuva como solução viável para a retenção do volume de água calculado, apresentando, tanto para equipe técnica de engenharia quanto para a diretoria da Fiocruz, a possibilidade do uso de Infraestruturas Verdes como uma solução promissora para atingir os objetivos da certificação, em solução de menor impacto construtivo sobre o empreendimento e de maior potencial de qualificação paisagística do conjunto.

A apresentação das soluções de IEV para a equipe utilizou os modelos de jardins de chuva existentes no exterior, tais como aqueles encontrados em Seattle (EUA), Portland (EUA) e Venlo (Holanda). Porém, uso de exemplos exclusivamente em países com climas distintos do Brasil gerou um forte questionamento, por parte de todos aqueles que estavam tendo contato pela primeira vez com a tecnologia, se tais soluções seriam aplicáveis às nossas condições ambientais. Infelizmente, no momento ainda não havia qualquer exemplo brasileiro de aplicação de jardins de chuva que pudesse responder aos questionamentos.

Apesar da resistência, a Fiocruz aceitou o desafio de desenvolver o projeto de drenagem baseado no uso de jardins de chuva, reiniciando, de forma tardia, os projetos de drenagem e de paisagismo.

Dessa forma, o novo projeto de drenagem e paisagístico foi iniciado pela identificação das potencialidades das áreas livres do campus como espaços passíveis de incorporação ao sistema de drenagem. Um estudo pormenorizado da implantação e escoamento superficial do campus em sua relação com as áreas ajardinadas permitiram um cálculo mais pormenorizado das demandas de retenção nos diferentes setores do terreno.

A criação de áreas de retenção foi a primeira meta buscada no estabelecimento das tipologias de IEV a serem adotadas. Com base nas diferentes vazões das distintas bacias de contribuição, foi estabelecida a necessidade de criação de um volume de retenção de águas pluviais compatível com a contribuição de 60 minutos da maior precipitação.

Desta forma temos para o período de 1 hora de volume acumulado:

\begin{tabular}{cccccc}
\hline $\begin{array}{c}\text { BACIA 01 } \\
\left(\mathrm{m}^{3}\right)\end{array}$ & $\begin{array}{c}\text { BACIA 02 } \\
\left(\mathrm{m}^{3}\right)\end{array}$ & $\begin{array}{c}\text { BACIA 03 } \\
\left(\mathrm{m}^{3}\right)\end{array}$ & $\begin{array}{c}\text { BACIA 04 } \\
\left(\mathrm{m}^{3}\right)\end{array}$ & $\begin{array}{c}\text { BACIA 05 } \\
\left(\mathrm{m}^{3}\right)\end{array}$ & $\begin{array}{c}\text { VOLUME } \\
\text { TOTAL } \\
\left(\mathrm{m}^{3}\right)\end{array}$ \\
\hline 397,32 & 606,04 & 239,05 & 242,64 & 333,35 & 1818,40 \\
\hline
\end{tabular}


Foram escolhidas as áreas verdes para criação de jardins de chuva que promoveriam a retenção desse volume. Concebidos apenas como uma depressão topográ fica através de movimentação do solo, foram de finidas 54 unidades de retenção, os jardins de chuva, distribuídos ao longo de todo o sistema viário do campus e estacionamentos.

Nomeadas pelo projeto de drenagem apenas como "valas", as unidades de retenção foram concebidas com margens taludadas, adquirindo seção trapezoidal, e adquiriram diferentes profundidades, compatíveis com as áreas verdes disponíveis e a contribuição de vazão que contemplam. Em seu fundo, receberam camada de brita e areia grossa para proporcionar maior capacidade de in filtração no solo. Ver Figura 83.

O cálculo do volume de cada unidade segue abaixo.

\begin{tabular}{|c|c|c|c|c|c|}
\hline VALA & $\begin{array}{c}\text { CA P AC IDADE } \\
\left(\mathrm{m}^{3}\right)\end{array}$ & VALA & $\begin{array}{c}\text { CA P ACIDADE } \\
\left(\mathrm{m}^{3}\right)\end{array}$ & VALA & $\begin{array}{c}\text { CA PAC IDADE } \\
\left(\mathrm{m}^{3}\right)\end{array}$ \\
\hline V01 & 47,90 & V16 & 6,55 & V35 & 616,25 \\
\hline V02 & 73,96 & V17 & 14,80 & V35a & 12,24 \\
\hline V03a & 15,75 & V18 & 66,12 & V35b & 150,04 \\
\hline V03b & 15,75 & V19 & 13,42 & V36 & 9,04 \\
\hline V03c & 15,75 & V20 & 12,07 & V37 & 9,04 \\
\hline V04 & 28,27 & V21 & 15,96 & V38 & 9,04 \\
\hline V05 & 31,22 & V22 & 6,75 & V39 & 9,04 \\
\hline V06 & 27,13 & V23 & 68,50 & V40 & 9,04 \\
\hline V07 & 28,37 & V24 & 48,09 & V41 & 9,04 \\
\hline V08 & 26,39 & V25 & 11,24 & V42 & 9,04 \\
\hline V09 & 24,37 & V26 & 11,24 & V43 & 9,04 \\
\hline V10 & 28,82 & V27 & 11,24 & V44 & 13,67 \\
\hline V11 & 25,22 & V28 & 11,24 & V45 & 11,24 \\
\hline V12 & 12,55 & V29 & 11,24 & V46 & 11,24 \\
\hline V13 & 3,65 & V30 & 19,74 & V47 & 11,24 \\
\hline V13a & 7,77 & V31 & 12,87 & V48 & 11,24 \\
\hline V13b & 0,32 & V32 & 6,75 & V49 & 11,24 \\
\hline V14 & 11,48 & V33 & 163,63 & V50 & 11,24 \\
\hline V15 & 3,56 & V34 & 255,24 & & \\
\hline
\end{tabular}




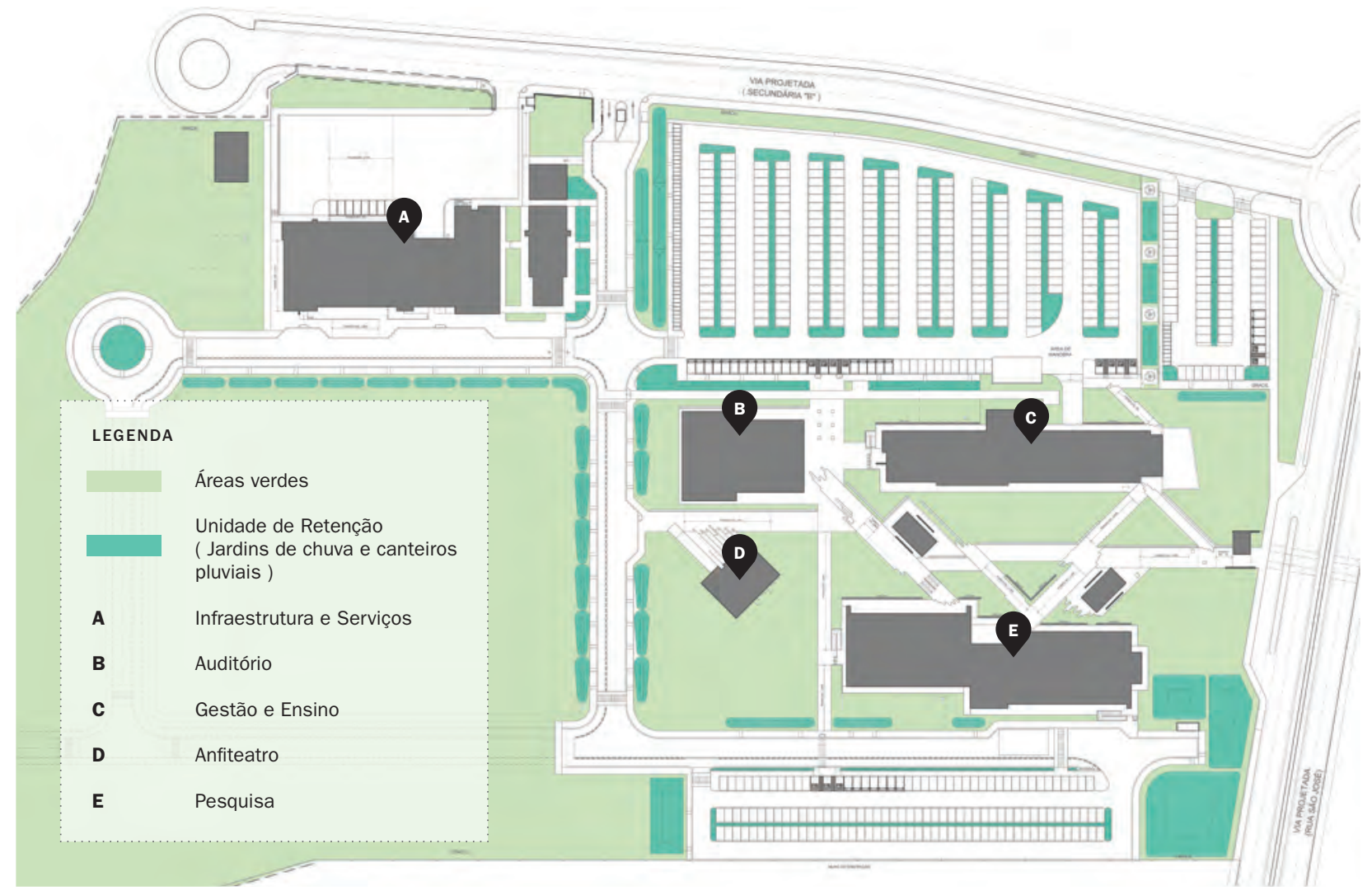

Planta 05 | Definição das unidades de retenção nas áreas livres do complexo adjacentes às áreas de contribuição (vias e passeios). Planta elaborada pelo autor com base no projeto executivo fornecido pela ARCHITECTUS S/S.

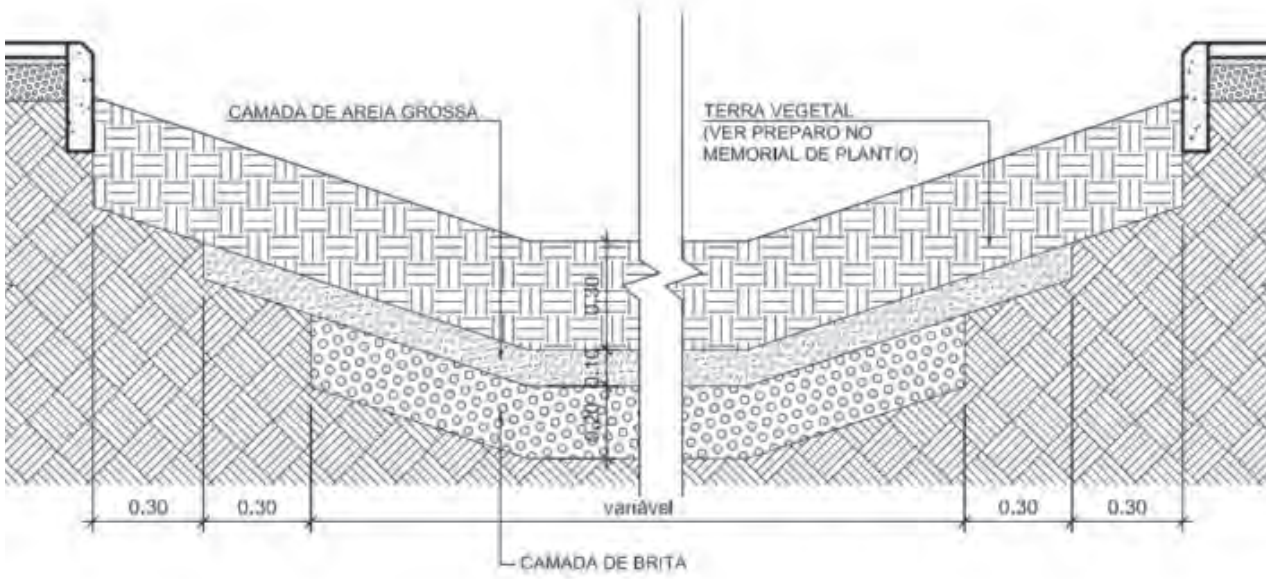

Desenho 10 | Seção típica das unidades de retenção. 0 tratamento com diferentes granulometrias do fundo tem como objetivo assegurar uma maior capacidade de infiltração das águas retidas. Fonte: ARCHITECTUS S/S. Projeto de Drenagem Campus Fiocruz Ceará. 
O somatório dos volumes de retenção criado atingiu o valor de $2127,14 \mathrm{~m}^{3}$, portanto um volume superior ao total acumulado durante 60 minutos de precipitação $\left(1818,40 \mathrm{~m}^{3}\right)$. Esse cálculo ignora a taxa de permeabilidade das valas, característica que garantirá um aumento substancial do tempo de retenção das águas, o que pode apontar para um possível superdimensionamento do sistema de retenção projetado. Essa possibilidade se torna mais evidente ao considerar o solo do local, o qual, através de teste de absorção realizado, apontou taxas que variam de 25 a $90 \mathrm{~L} / \mathrm{m}^{2} /$ dia, portanto, viáveis para a implantação unidades de retenção.

Mesmo com tal dimensionamento, o sistema de drenagem projetado ainda considerou a possibilidade de um evento de precipitação superior ao volume calculado, mantendo um sistema convencional de drenagem como alternativa de emergência que permitisse o extravasamento dos jardins de chuva, captando o excedente para um sistema subterrâneo que o conduz para uma cisterna convencional e filtro vortex, tal como anteriormente previsto.

Naturalmente, a adoção de jardins de chuva promoveu não só a garantia da retenção e infiltração das águas pluviais no solo, como também trará relevantes contribuições para controle da poluição difusa e erosão, melhorando a qualidade das águas pluviais do campus.

Desta forma, assim foi descrito o sistema adotado no memorial descritivo do projeto de drenagem do campus: 


\begin{abstract}
no solo removem os poluentes difusos trazidos pelo escoamento superficial. A adição de plantas aumenta a evotranspiração e a remoção de nutrientes.
\end{abstract}

Nas vias o sistema de drenagem funcionará através das sarjetas que conduzirão as águas até as bocas-de-lobo ligadas às bacias de retenção. Desse modo, a água pluvial será absorvida gradualmente pelo próprio terreno." (ARCHITECTUS. Memorial Descritivo do Projeto Executivo de Arquitetura Fiocruz Unidade Ceará)

Alguns elementos de urbanismo sofreram adaptações em seu desenho, como, por exemplo, a boca de lobo que foi convertida em uma passagem sob o passeio, conduzindo as águas das sarjetas em direção aos jardins de chuva adjacentes. Foram criados extravasores localizados dentro das unidades de retenção que cumprem o papel de controle da cota de transbordamento, escoando o eventual volume não suportado pela unidade de retenção. 0 maior impacto visual promovido pela instalação das Infraestruturas Verdes no campus diz respeito ao tratamento paisagístico conferido aos jardins e chuva e canteiros pluviais.

Para incremento da capacidade de retenção de poluentes carreados pelas águas das chuvas, optou-se pelo uso de vegetação herbácea no interior das unidades de retenção. Por conta das características climáticas locais, caracterizada por períodos de intensas chuvas durante em um curto período do ano (entre fevereiro e maio) e um longo período de estiagem (junho a janei-
Gráfico 07 | Configuração final do sistema de drenagem adotado. Gráfico elaborado pelo autor com base no projeto executivo fornecido pela ARCHITECTUS S/S.

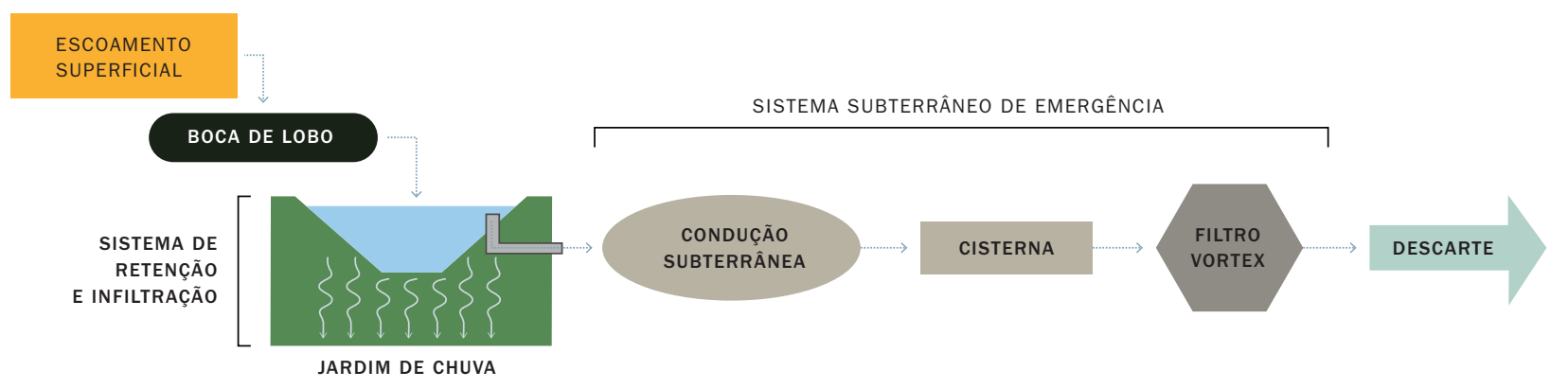




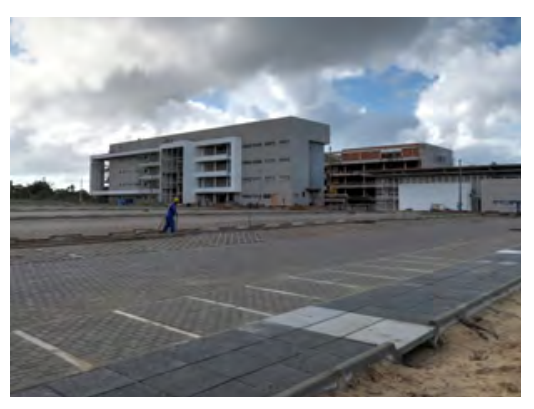

Foto 68 | Estrutura de captação e condução das águas pluviais executada junto ao passeio. Fotos da obra em março/2016. Autor: Gerson Amaral.

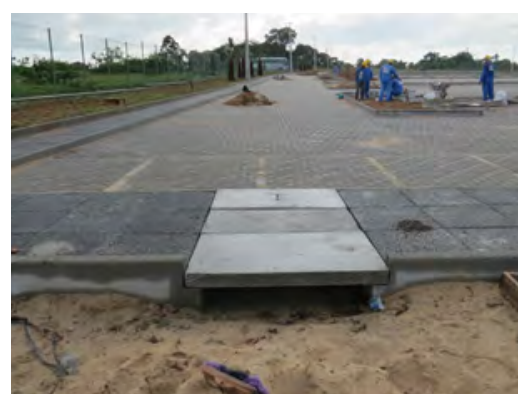

Foto 69 | Aspecto do elemento de captação e condução das águas pluviais para os jardins de chuva (ainda em processo de implantação). Local: estacionamento. Fotos da obra em março/2016. Autor: Gerson Amaral. ro), a vegetação adotada deveria estar adequada aos distintos períodos, suportando momentos de grande umidade do solo e até formação de espelhos d'agua em curtos períodos, assim como suportando relativo déficit hídrico ao longo da maior parte do ano, exigindo o mínimo possível de irrigação.

A resposta mais adequada a essas condições foram achadas na investigação da flora local. Já adaptada às adversidades do clima semiárido, assim como às condições de solo, salinidade e cheias periódicas, um conjunto de plantas palustres de ocorrência nas margens dos rios da região ofereciam características botânicas adequadas ao uso nos jardins de chuva. Do conjunto identificado, foram escolhidas aquelas espécies que possuíam porte e aspecto mais adequados aos objetivos paisagísticos do campus. Foram selecionados 03 espécies herbáceas nativas de valor ornamental: a Ipomoea carnea, Acrostichum aureum e a Canna glauca. Complementarmente foi utilizada a espécie Canna indica para incrementar a paleta de cores dos maciços vegetais.

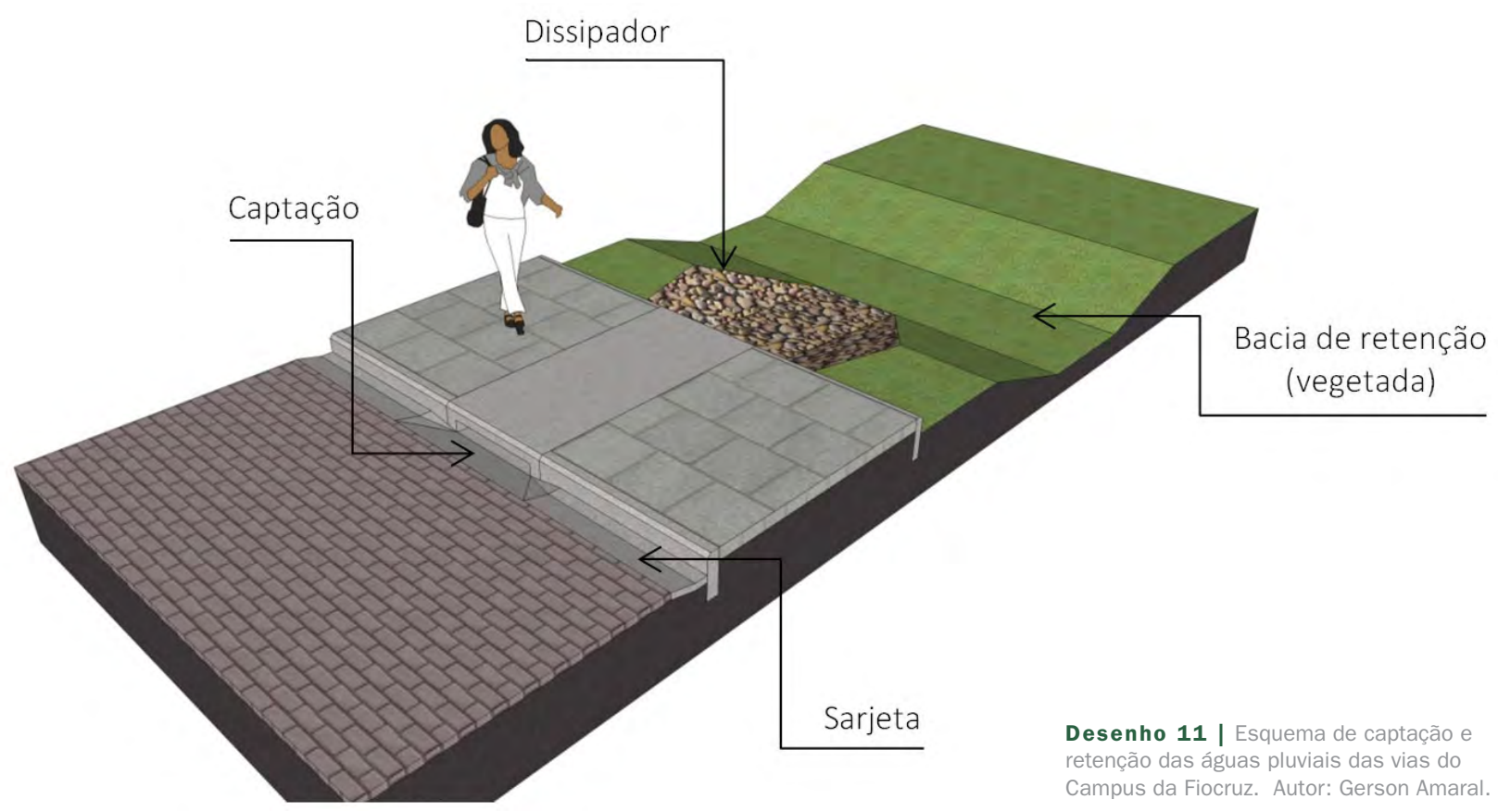


Nos jardins de chuva maiores, por sua vez, foram utilizadas espécies de maior porte como a Carnaúba (Copernicia prunifera), que é notória por cobrir extensas várzeas de inundação da região, o Guajiru (Chrysobalanus icaco) e o Torém (Cecropia pachystachya), igualmente resistentes a solos sujeitos a períodos de inundação.

As demais áreas ajardinadas do campus receberam espécies prioritariamente nativas ou adaptadas à região, contanto que não se caracterizassem como espécies invasoras do bioma local.

Palmeiras rústicas como a Guariroba (Syagrus oleracea) e o Licuri (Syagrus coronata) foram adotadas como estratégia de incorporação de vegetação pouco exigente a irrigação ainda pouco exploradas em projetos paisagísticos da região. Pela rusticidade e ampla ocorrência na no bioma local foi utilizada a palmeirinha Catolé (Syagrus cearensis), já consagrada no paisagismo cearense.

Foram inseridas também espécies arbóreas típicas da caatinga cearense tais como o Cumaru (Amburana cearensis), a Barriguda (Ceiba glaziovii), o Pau-branco (Cordia oconcalyx), o Trapiá (Crataeva tapia), o Juazeiro (Zizyphus joazeiro), etc.

Das matas de tabuleiro foram incorporados o Pereiro (Aspidosperma pyrifolium), Pau-ferro (Caesalpinia ferrea var. ferrea) o Pau-ferro-da-praia (Chamaecrista ensiformis), a Janaguba (Himathantus drasticus), o Pau-mocó (Luetzelburgia auriculata), o Pau-d'Arco-Amarelo (Tabebuia serratifolia), entre outras.

Maciços de herbáceas foram compostos com o uso de Clusias (Clusia fluminensis), Alamandas (Allamanda nerifolia), Macambira (Encholirium spectabilis), Triális (Galphimia brasiliensis), Cambará (Lantana camara), entre demais espécies de ampla utilização paisagística como Pandanus, Espada-de-São-Jorge, Moreia, Dianelas etc. que complementaram a composição florística do paisagismo. 


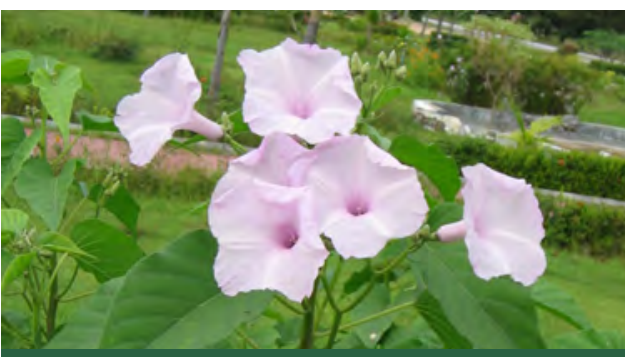

Foto 70 | Algodão-bravo - Ipomoea carnea.

Fonte: http://tropical.theferns.info/viewtropical. php?id=lpomoea+carnea. Acesso em 25/03/2015.

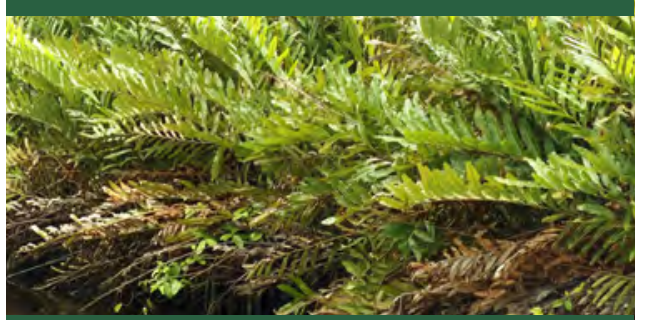

Foto 71 | Samambaia-gigante-do-brejo - Acrostichum aureum. Fonte: http://tropical.theferns.info/image. php?id=Acrostichum+aureum.

Acesso em 25/03/2015.

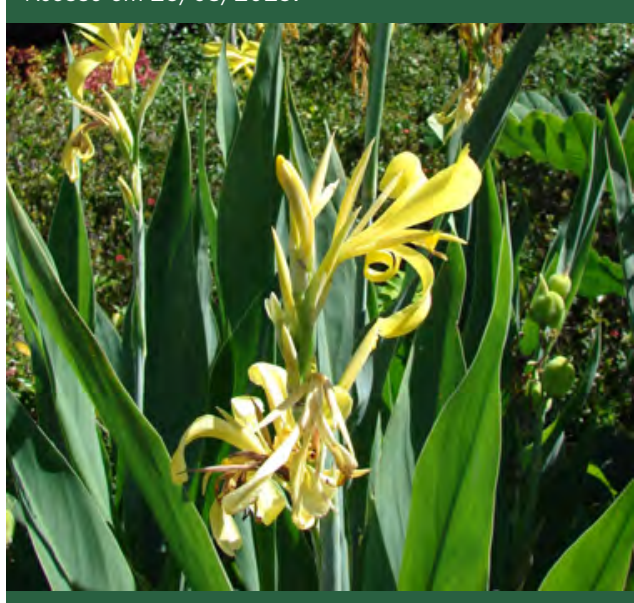

Foto 72 | Piriquiti - Canna glauca. Fonte: http://tropical.theferns.info/viewtropical. php?id=Canna+glauca. Acesso em 28/03/2015.

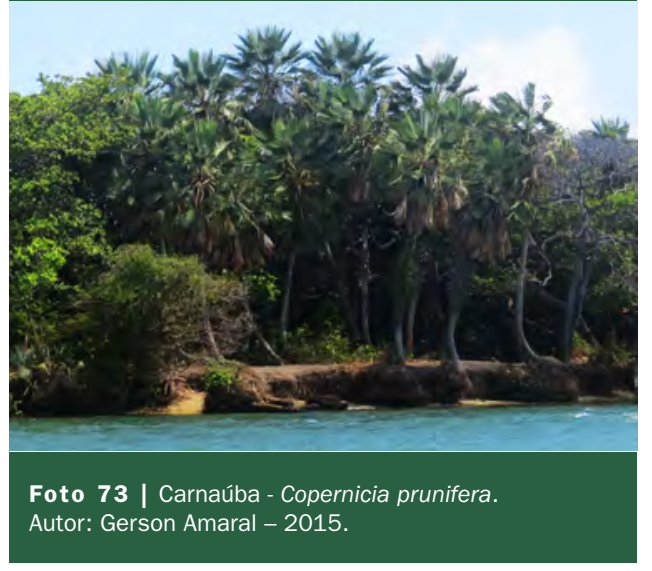

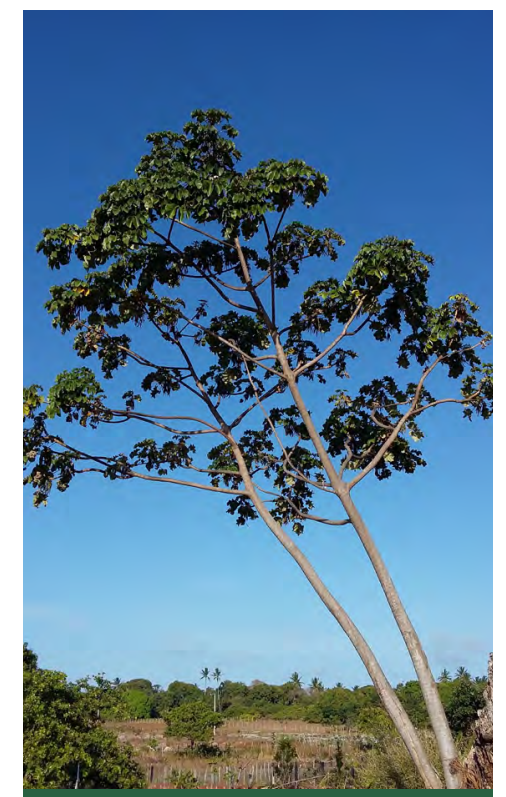

Foto 75 | Torém - Cecropia

pachystachya. Autor: Gerson Amaral, 2015

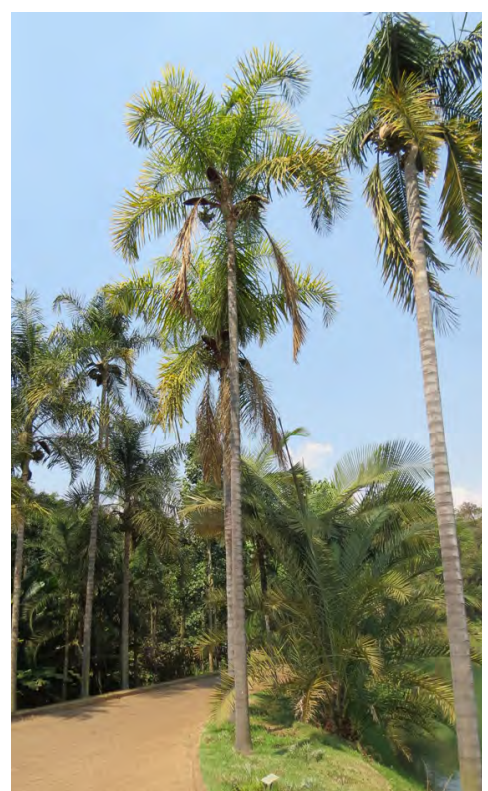

Foto 76 | Guariroba - Syagrus

oleracea. Autor: Gerson Amaral - 2014

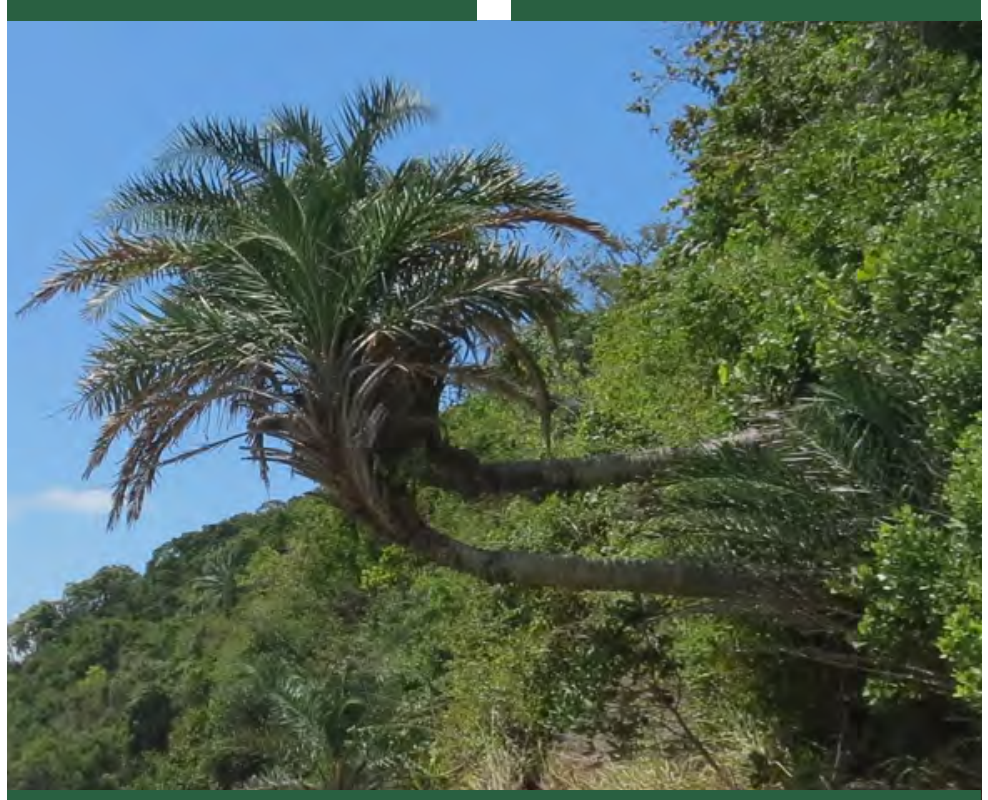

Foto $\mathbf{7 7}$ | Licuri - Syagrus coronata.

Autor: Gerson Amaral - 2015

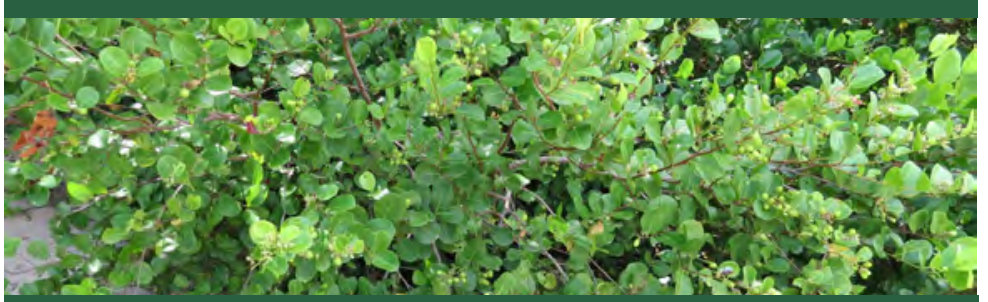

Foto 74 | Guajiru - Chrysobalanus icaco.

Autor: Gerson Amaral - 2015. 


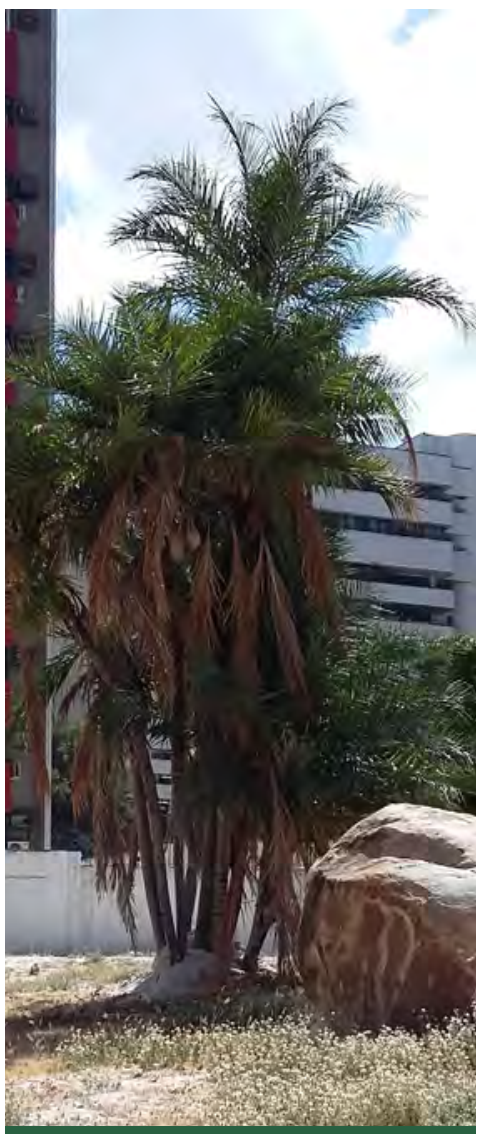

Foto 78 | Catolé - Syagrus cearensis. Autor: Gerson Amaral - 2014

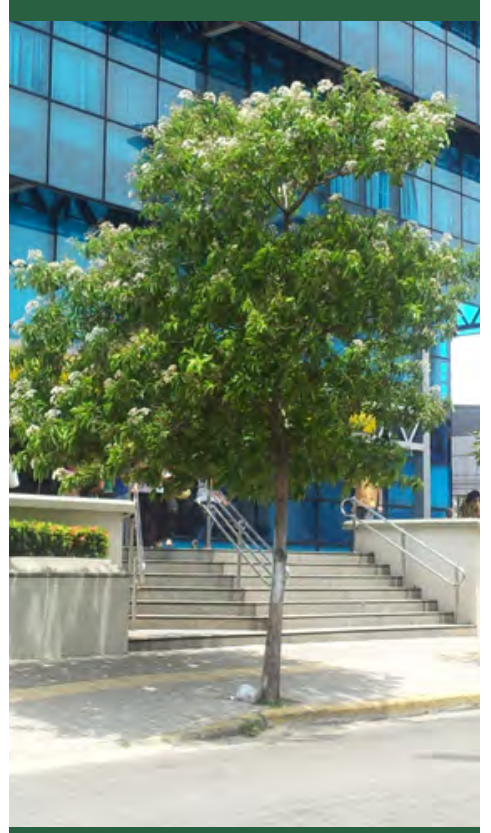

Foto 79 | Pau-branco - Cordia

oconcalyx. Autor: Gerson Amaral, 2013.

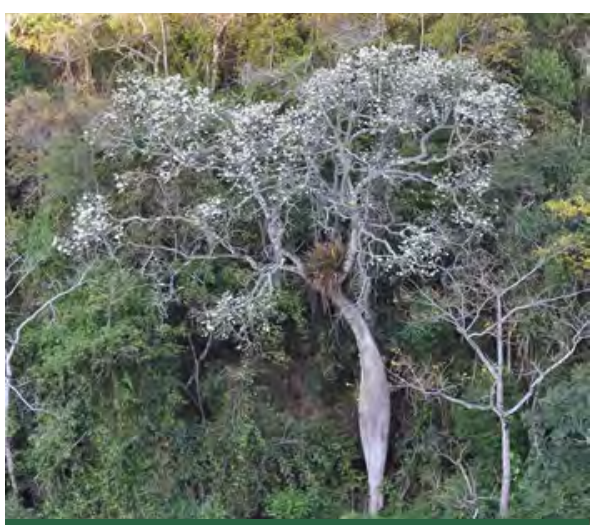

Figura 80 | Barriguda - Ceiba glaziovii. Autor: Antônio Sérgio - 2015.

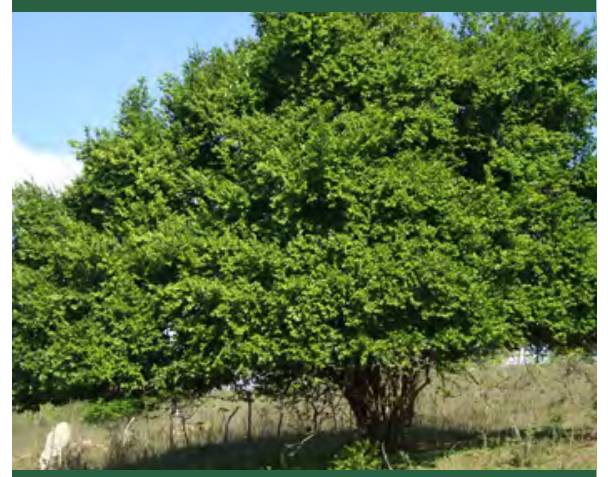

Foto 81 | Juazeiro - Ziziphus joazeiro.

Fonte: $h$ ttp://tropical.theferns.info/viewtropical.

php?id=Ziziphus+joazeiro. Acesso em 29/03/2015.
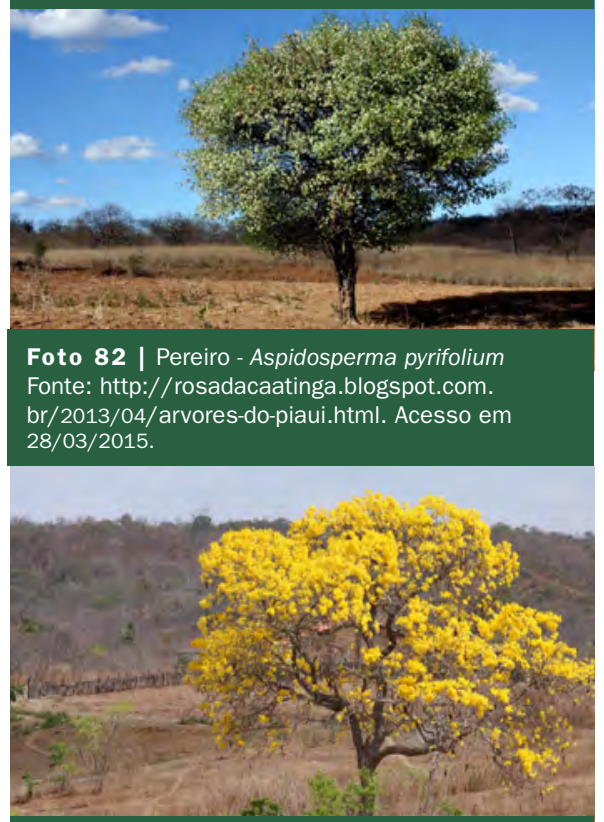

Foto 83 | Pau-d'arco-amarelo - Tabebuia

serratifolia. Fonte: http://rosadacaatinga.blogspot.

com.br/2013/04/arvores-do-piaui.html. Acesso

em 24/03/2015

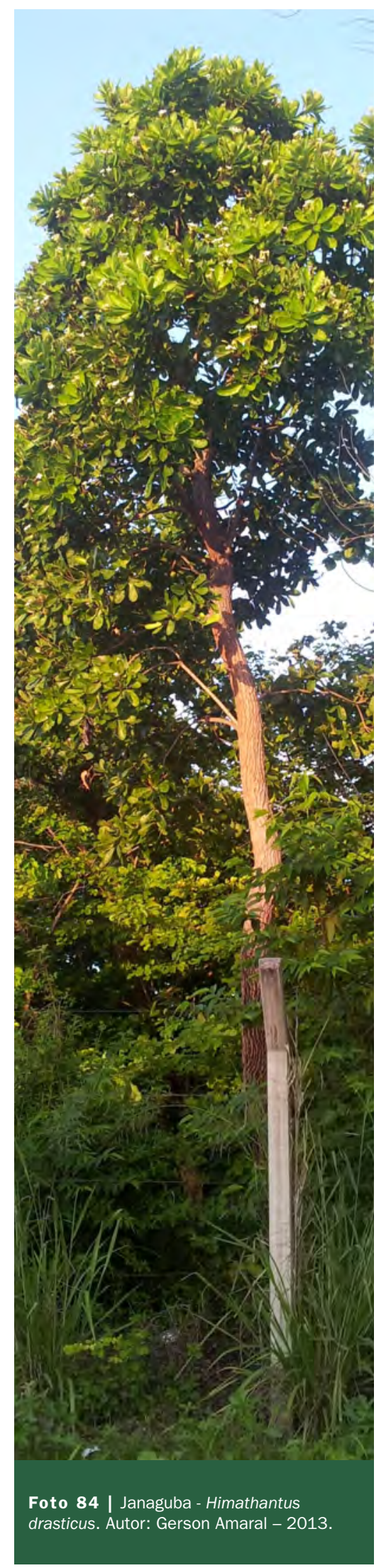




\section{6}

\section{Discussão}

A introdução das Infraestruturas Verdes no projeto de drenagem do campus da Fiocruz enfrentou grande resistência desde a sua proposição inicial. 0 trabalho de introdução dos seus conceitos, convencimento de sua viabilidade e comprovação de sua eficiência se estendeu desde as primeiras reuniões com o corpo administrativo da Fiocruz, deu sequência no embate com o corpo técnico de projetistas e com o empreiteiro da obra, enfrentando certa resistência. A falta de exemplos práticos de referência nacional se apresentou, desde o início, como uma barreira para o convencimento de sua aplicabilidade no contexto local. Exemplos internacionais, majoritariamente de países de clima temperado, não convencem, dadas as diferenças ambientais e urbanísticas que condicionavam o sistema e consequentemente o seu aspecto.

A resistência ao conceito de retenção das águas pluviais geraram impasses projetuais durante o processo. Acostumados com o tradicional conceito de aceleração do escoamento pluvial para imediata expulsão do ambiente construído, os projetistas de drenagem resistiam às soluções técnicas indicadas pelas Infraestruturas Verdes, pondo em risco a sua eficiência técnica. Tal como podemos observar nos primeiros detalhamentos dos extravasores dos jardins de chuva que insistentemente eram projetados no nível de fundo das unidades de retenção, impossibilitando o acúmulo de água, portanto reduzindo o processo de retenção e infiltração. Após insistentes intervenções técnicas, a solução correta (com extravasor no nível da cota de transbordamento) somente foi acatada após um parecer técnico da agência certificadora que alertou para o descumprimento das determinações do SGE, ameaçando rebaixar a pontuação da categoria Gestão da Água no processo de certificação.

A preocupação em evitar o empoçamento das águas é um fato deveras justificado, ainda mais em um momento histórico brasileiro marcado por um número alarmante de casos de epidemias tropicais graves tais como a dengue, a febre chikungunya e o 

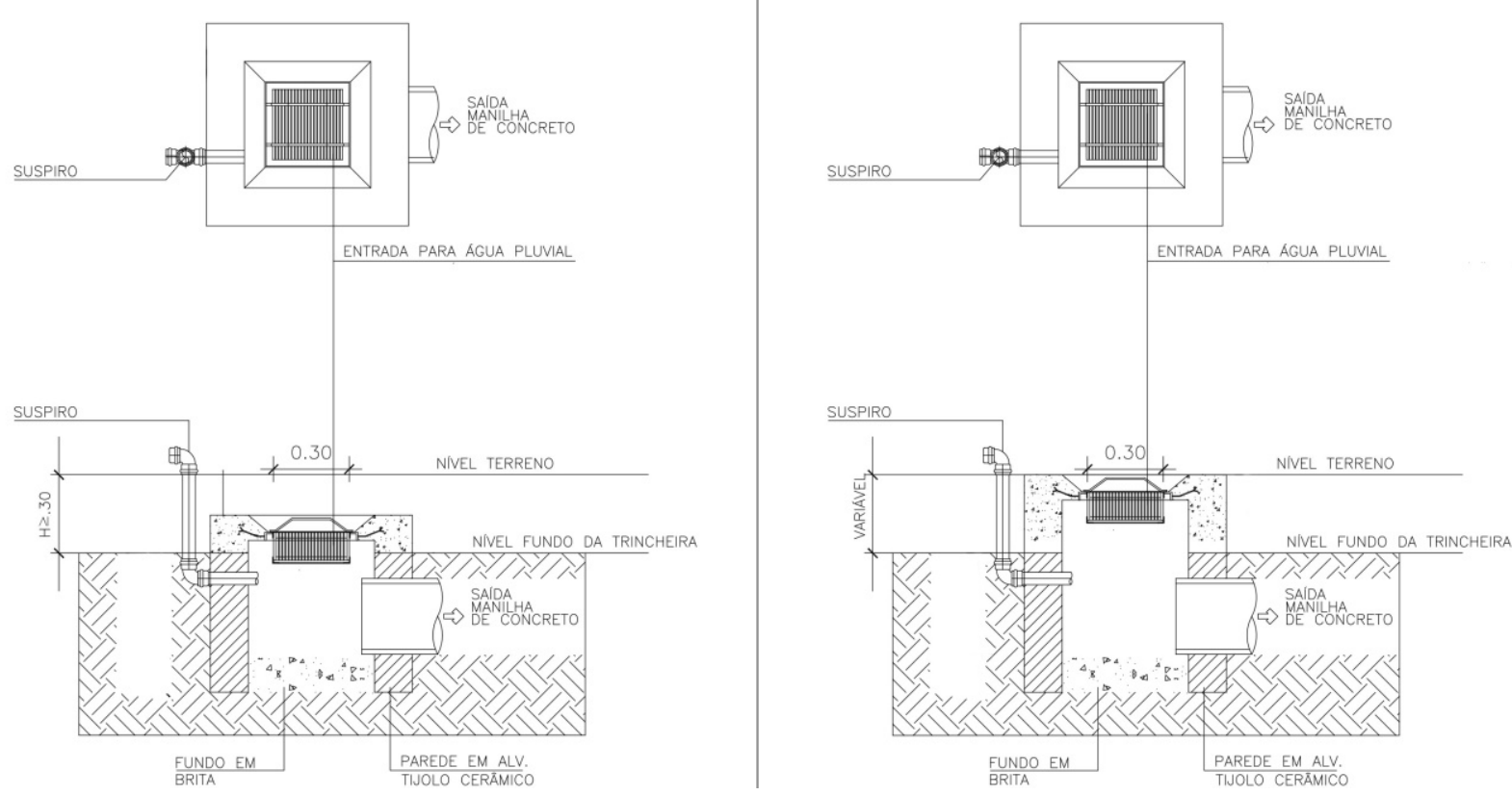

zika. Todas essas doenças estão associadas ao mesmo vertor,

Desenho 12 | Diferenças entre o primeiro detalhamento do extravasor (a esquerda) e a versão final, alinhada com os princípios o mosquito Aedes aegypti, cuja reprodução é facilitada pela preda IEV. Fonte: ARCHITECTUS S/S. Projeto de sença de águas paradas, onde são postos os ovos e posteriorDrenagem do Campus Fiocruz Ceará. mente se desenvolvem as larvas que caracterizam a primeira fase da vida do mosquito. Nas áreas de ocorrência do mosquito Aedes aegypti, portanto, o uso de infraestrutras verdes deve atentar para não contribuir na criação de habitats favoráveis a sua reprodução. As soluções de jardins de chuva e biovaletas, portanto, devem atentar para o correto dimensionamento com base nas áreas de contribuição, na capacidade de absorção do solo e mecanismos de drenagem associados, evitando, assim, o acúmulo de água por período superior ao planejado.

Como é corriqueiro em um empreendimento desse porte e complexidade, desde o início das obras ajustes de projeto são frequentemente solicitados, seja por incompatibilidades de projeto, mudanças na tomada de decisões ou complicações de obra. Com o sistema de drenagem não foi diferente. 


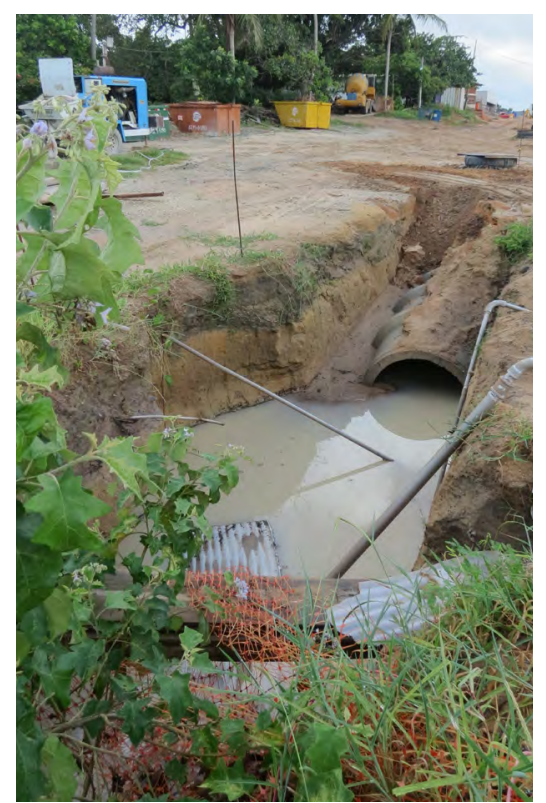

Figura 85 | Local previsto para construção da cisterna de retenção. Nível do lençol freático impossibilitou sua execução. Fonte: Gerson Amaral, em março de 2016.
Em uma primeira etapa de execução foi instalado o sistema subterrâneo de condução das águas pluviais composto por anilhas de concreto e poços de visita, alinhados pelos eixos do sistema viário e níveis determinados em projeto. Como já explicitado, o projeto previa a existência de uma cisterna de detenção ao final da tubulação que, por sua vez, conduzia ao filtro vórtex e posterior descarte das águas. Executada a tubulação, contudo, um fator comprometeu seriamente o sistema previsto: o nível final da tubulação acabou atingindo o nível do lençol freático.

Mais do que evidenciar uma variação imprevista do nivel do lençol freático ao longo do ano, a falha resultante tem uma causa que remete à decisões das mais essenciais do projeto que são as diretrizes de ocupação do terreno. 0 traçado urbanístico e a implantação das edificações, como se constata, foi determinado por um padrão ortogonal de organização que pouco dialoga com as características físicas do sítio, especialmente sua topografia. Em termos de drenagem das águas pluviais, essa falta de diálogo resulta em um comportamento, quase sempre, indesejado do escoamento superficial. 0 sistema subterrâneo, portanto, trabalha em compensação de níveis, algumas vezes conduzindo o volume em sentido contrário ao natural da topografia, para lançamento em áreas de menor cota. Tal foi o motivo do excessivo rebaixamento do nível da tubulação do campus.

Considerando a inadequabilidade de execução de uma cisterna de detenção em nível inferior ao nível do lençol freático, mais uma vez as infraestruturas verdes contribuíram para solucionar impasses projetuais. Como alternativa técnica de descarte final do sistema, a cisterna e filtro vórtex foram substituídos por uma lagoa pluvial associada a uma caixa separadora de água e óleo. A solução combina, desta forma, solução de retenção das águas, fitorremediação e filtragem antes do descarte final, além da criação de um habitat para animais silvestres, especialmente peixes e aves aquáticas. 


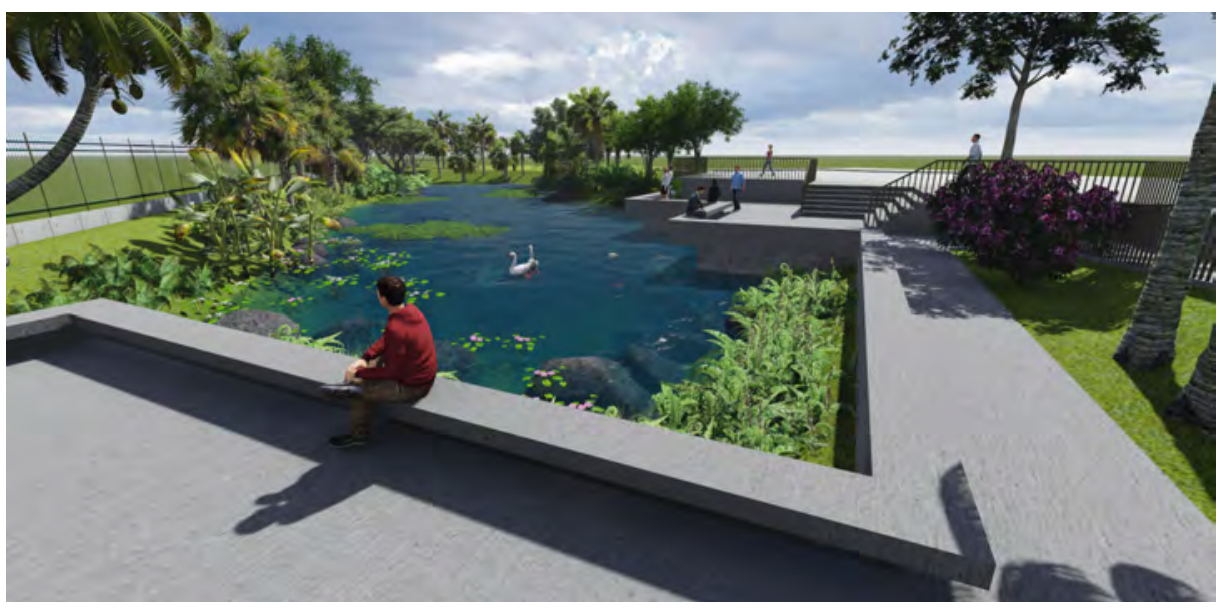

Desenho 13 | Perspectiva do projeto para lagoa pluvial em substituição a cisterna de detenção e filtro vortex. Fonte: ARCHITECTUS S/S. Projeto de Drenagem do Campus Fiocruz Ceará.

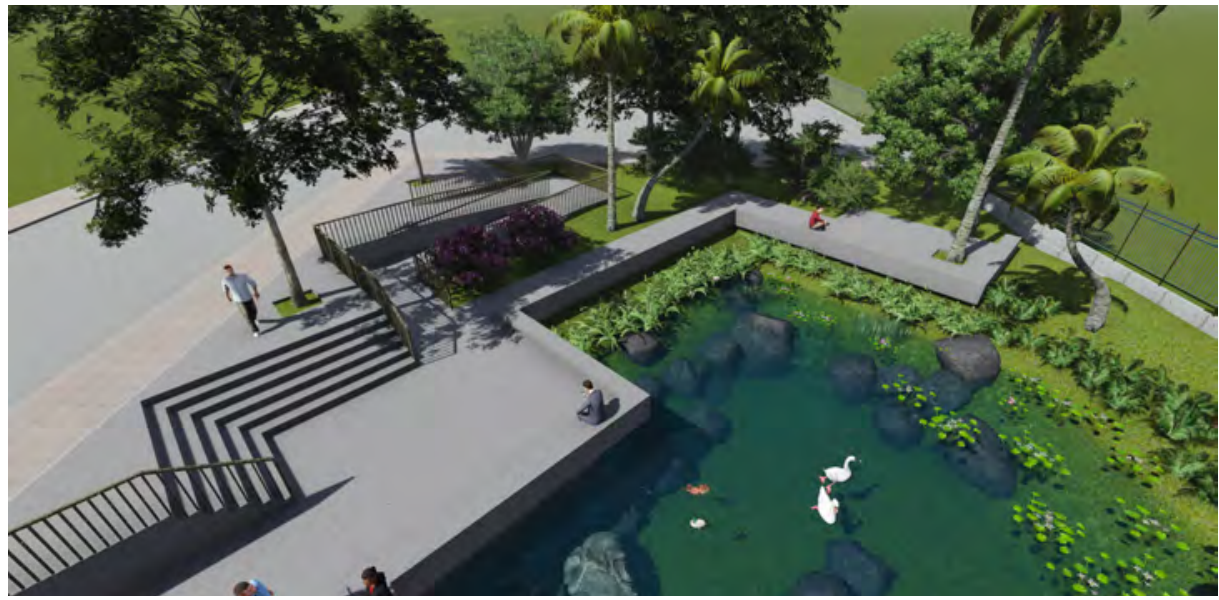

Desenho 14 | Perspectiva do projeto da lagoa pluvial. A ideia de criação do corpo d'agua incentivou o aproveitamento de sua qualidade espacial para a criação de áreas livres de lazer contemplativo. Fonte: ARCHITECTUS S/S. Projeto de Drenagem do Campus Fiocruz Ceará.

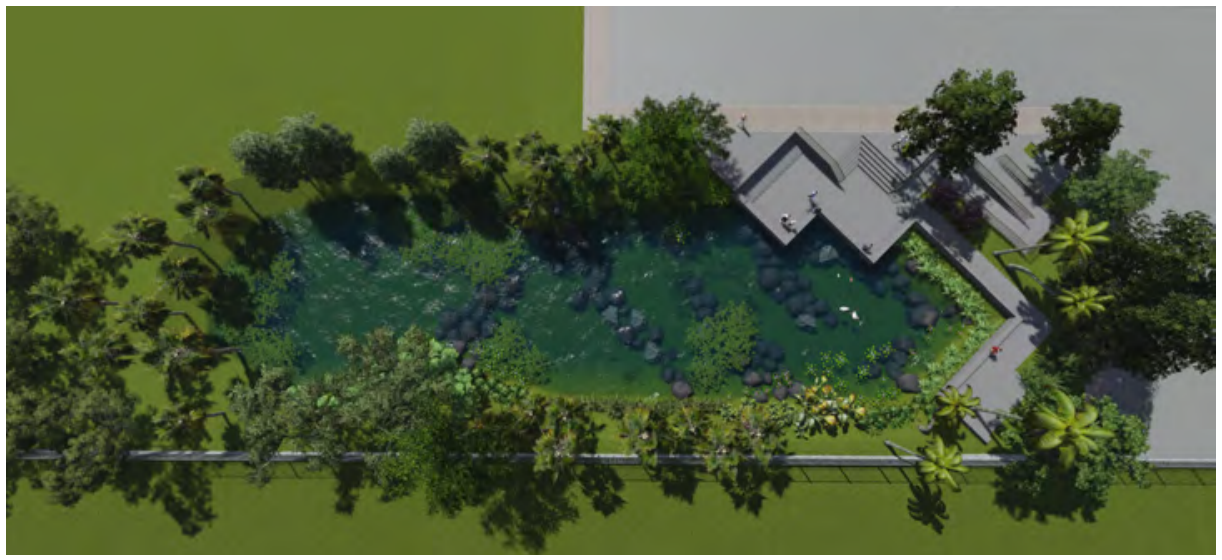

Desenho 15 | Perspectiva do projeto da lagoa pluvial. Concebida também para servir de habitat para peixes e aves aquáticas, incorporando espécies vegetais locais para incremento da biodiversidade. Fonte: ARCHITECTUS S/S. Projeto de Drenagem do Campus Fiocruz Ceará. 
A criação da lagoa pluvial foi encarada como uma oportunidade de criação de um novo espaço de lazer contemplativo do campus, envolvendo um tratamento paisagístico apropriado com áreas pavimentadas e arborização, resultando em uma solução de baixo impacto, menor custo operacional e notório ganho na qualidade paisagística do campus.

Os problemas enfrentados pela obra comprovam a importância da profunda compreensão dos aspectos paisagísticos do território onde se trabalho, conhecendo seus recursos naturais e sua dinâmica própria. São esses fatores que, no ato de projetar, não devem ser vistos como dificuldades ou limitantes, mas sim encarados como potencialidades a serem incorporadas ao projeto e tornando-as naturalmente indutoras para alcance das melhores soluções técnicas.

Com a análise do projeto de Infraestrutura Verde do Campus da Fiocruz no Ceará é possível constatar a importância que teve o processo de certificação ambiental do empreendimento como mola propulsora para a busca de novas soluções projetuais de alto desempenho e baixo impacto. As Infraestruturas Verdes surgiram como solução mais adequada às exigências de manejo das águas pluviais e só pôde ser corretamente projetada e aceita pelo corpo de profissionais envolvidos após um trabalho contínuo de informação e convencimento por parte dos arquitetos paisagistas e da fundação certificadora.

Como relatado, o projeto de introdução dos conceitos de Infraestrutura verde no projeto do Campus da Fiocruz Ceará aconteceu de forma tardia dentro do cronograma de desenvolvimento do projeto. Sua incorporação aconteceu para solucionar um impasse projetual que surgiu pelas exigências técnicas da certificação.

Esse processo passa longe do modus operandi proposto pela ecologia da paisagem e, mais especificamente, pela proposta ideal de infraestrutura verde, afinal, para que o projeto tenha sucesso pleno na proposição de tecnologias de baixo impacto, esse conceito deve balizar todas as decisões projetuais, permeando todas as fases de projeto e disciplinas envolvidas.

A própria decisão de implantação do projeto no terreno determina fortemente o maior ou menor eficácia das IEVs. No caso da Fiocruz Ceará, a implantação previamente definida impossibilitou um melhor aproveitamento do potencial das áreas de estacionamento como áreas de reservação subterrânea das águas pluviais. O próprio arruamento, em conformação pouco ajustada ao relevo, trouxe complicações técnicas para a condução das águas pluviais. 
Os jardins de chuva projetados se limitaram a apêndices criados no conceito inicial de drenagem projetado, prejudicando de forma drástica a sua capacidade de integração paisagística dentro do desenho geral do campus e até na sua capacidade de retenção pelo melhor aproveitamento das áreas livres.

Para além das questões diretamente envolvidas como o manejo das águas pluviais, podemos encontrar outros pequenos detalhes projetuais que possuem um grande impacto no bioma local, como por exemplo o cercamento do terreno que, pelo uso de mureta com gradil, cria uma grande barreira física para o transito de animais em meio a área verde e seu acesso a lagoa. 0 simples fato de preservação de um bosque no terreno não garante a biodiversidade local se a conectividade ecológica dessa área não for assegurada. Um problema que foi gerado por uma tomada de decisão aparentemente sem grande relevância projetual como o desenho do cercamento do terreno. Tal é o motivo pelo qual os conceitos de ecologia da paisagem, tecnologias de baixo impacto e soluções de IEV devem contaminar toda a equipe técnica envolvida no projeto.

Naturalmente estamos tratando aqui de um projeto pioneiro no estado do Ceará, daí todos os problemas apontados. Porém, com a implantação definitiva do sistema, o acompanhamento de seu desempenho tratá significativos avanços para o aperfeiçoamento da tecnologia no Brasil, especialmente no contexto cearense. 

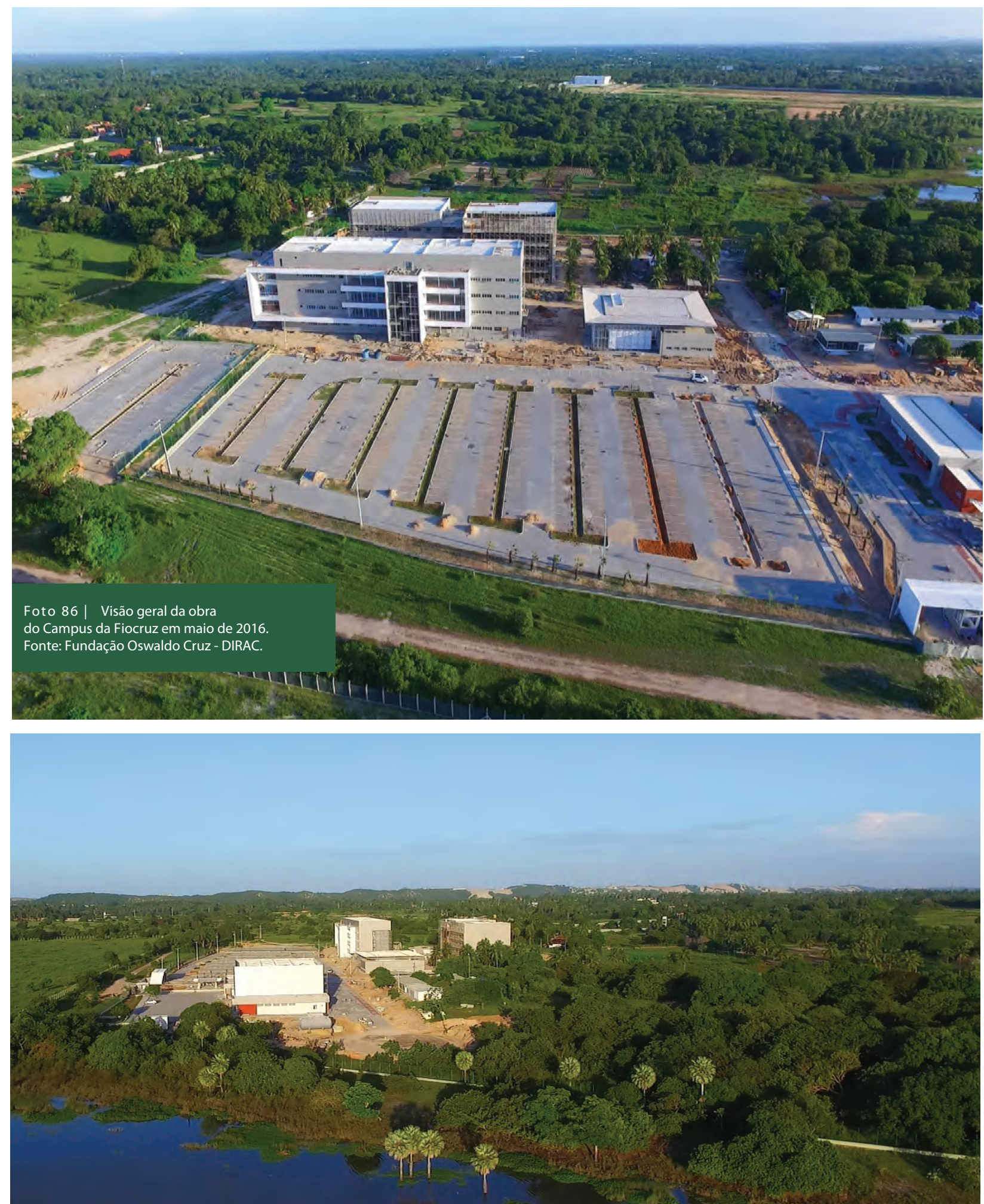

Foto 87 | Cercamento que delimita terreno

do campus corta área verde remanescente em

solução que quebra a continuidade ecológica da

regiăo para diversos seres vivos.

Fonte: Fundaçäo Oswaldo Cruz - DIRAC. 

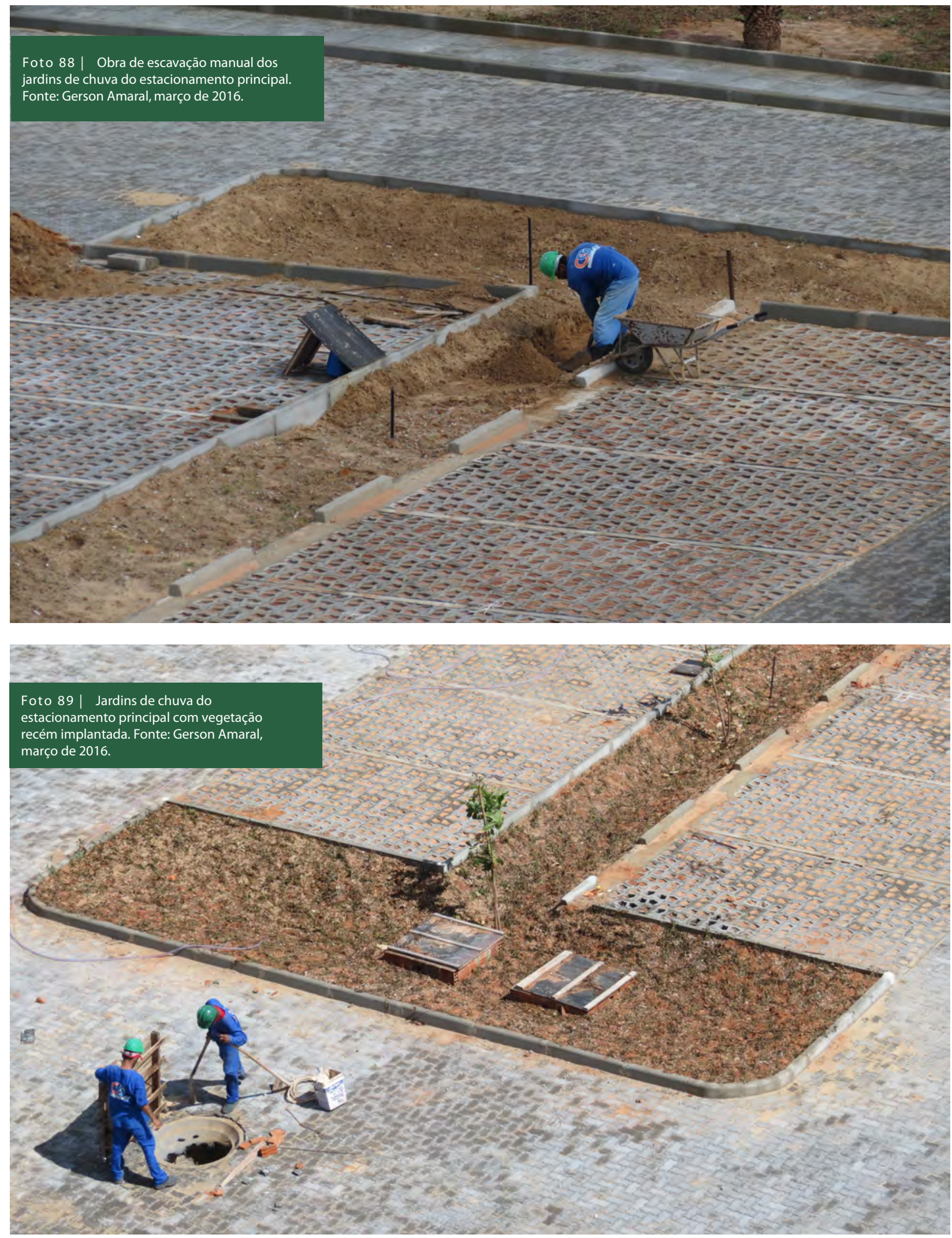

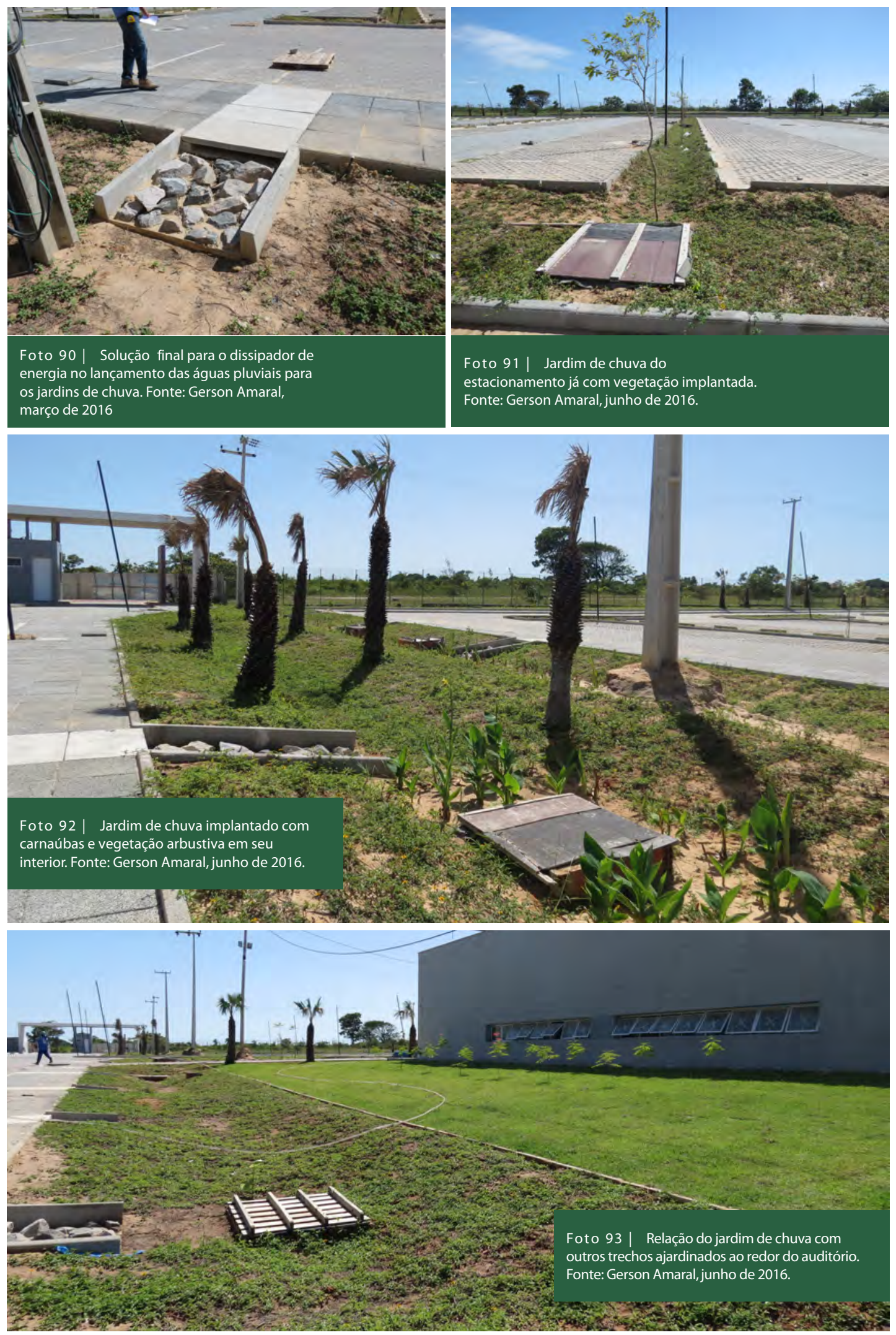

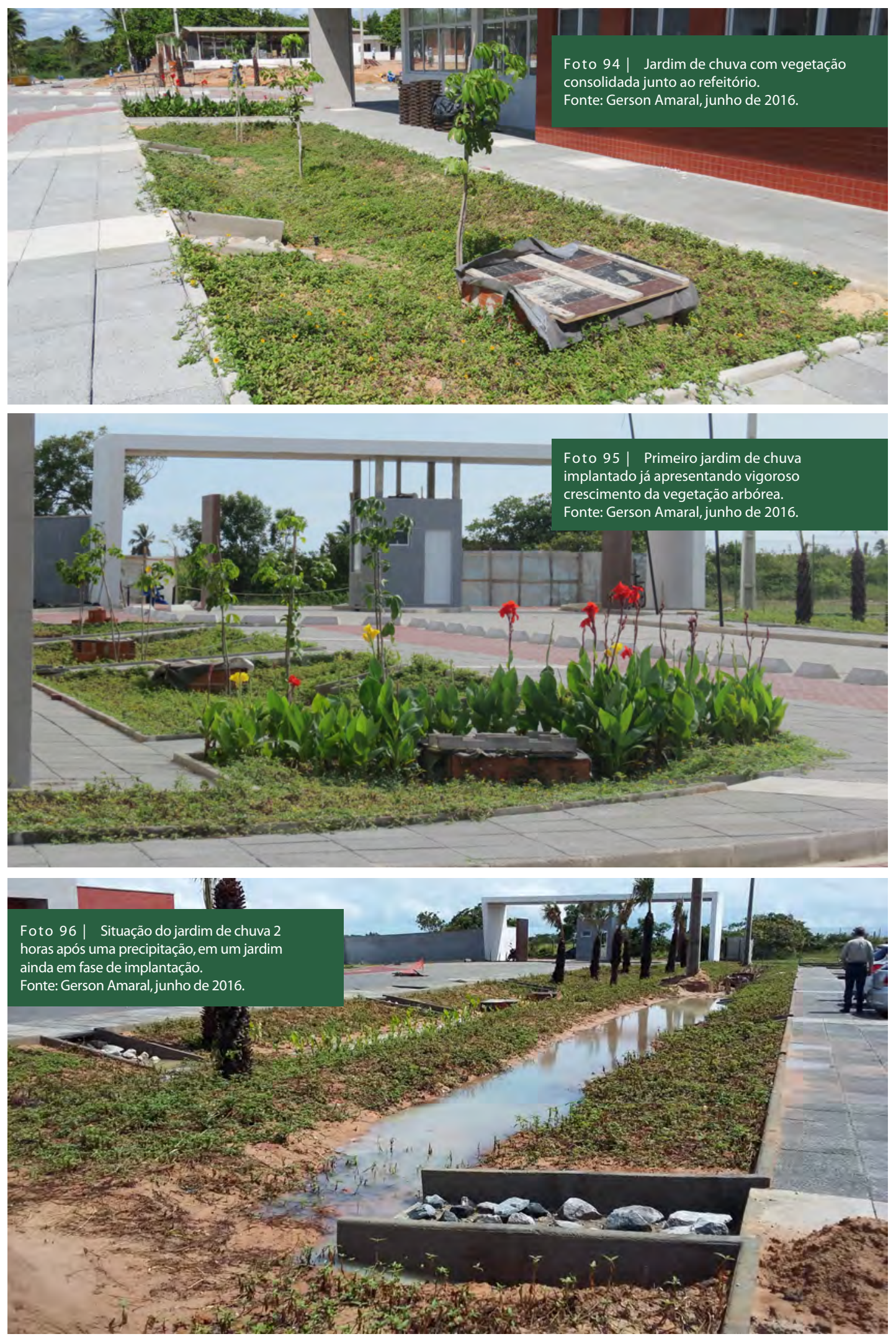


\section{7}

\section{Conclusão}

Por mais que o homem tenha estabelecido uma dicotomia entre a natureza virgem e o produto do trabalho humano, não é possível mais desconsiderar que a ambos estão integrados a um conjunto de processos comuns, condicionados igualmente ao meio e aos processos naturais. A cidade, enquanto uma das maiores intervenções do ser humano sobre a terra, não está dissociada dos processos naturais que incidem sobre sua base física. 0 reconhecimento, desses processos e a sua incorporação ao quotidiano citadino cada vez se demonstram mais eficientes do que as ações tradicionais de negação e controle dos processos naturais.

As Infraestruturas Verdes surgem, no século XXI como uma das mais eficientes respostas ao manejo sustentável das águas urbanas com ganhos imediatos para a preservação dos recursos naturais. Apesar da recente introdução de seus conceitos no Brasil, a sua aplicação prática já tem revelado sua viabilidade e apontado para todo o potencial ainda há para ser explorado.

Quebrar a inércia da forma tradicional e predatória de se manejar as águas urbanas das cidades brasileiras tem sido um desafio diário e contínuo. A introdução de novas abordagens se efetua de modo gradativo, na medida em que, através de aplicações práticas, é criado o seu próprio repertório e afirma-se como alternativa viável.

Por tais razões o estudo em pauta busca estar atento às indagações e posturas que hoje permeiam não só o campo do urbanismo, infraestrutura ou paisagem, mas toda a forma de encarar nossa relação com o mundo onde vivemos.

As soluções propostas pelas Infraestruturas Verdes buscam estabelecer uma nova forma de estruturação da paisagem ao entender melhor os impactos ambientais causados pelas novas configurações espaciais fruto da construção do espaço urbano contemporâneo. Conforme Milton Santos já destacou: 


\begin{abstract}
"a ordem espacial assim resultante é, também, intencional. Frutos da ciência e da tecnologia, esses objetos técnicos buscam a exatidão funcional, aspirando, desse modo, a uma perfeição maior que a da própria natureza. É desse modo que eles são mais eficazes que os objetos naturais e constituem as bases materiais para as ações mais representativas do período". (Santos, 2006)
\end{abstract}

Os princípios da Ecologia da Paisagem, e sua efetivação através da utilização de Infraestruturas Verdes seriam, pois, uma resposta contemporânea efetiva para a solução dos problemas referentes à qualidade das águas urbanas e o estabelecimento de uma nova relação do homem com o meio natural.

A elaboração do projeto de Infraestruutra verde da Fiocruz Ceará incorporou os novos conceitos na tentativa de criação de soluções de IEV adaptadas a ecologia e demandas locais. Quando tornar-se realidade, o campus inaugurará uma nova fronteira de pesquisa sobre o tema, confirmando ou não, através da observação e monitoramento de seu sistema de drenagem, a eficiência das soluções adotadas, e ajudará a amadurecer a tecnologia em território nacional. 



\section{B IB LIOGRAFIA}

ARCHITECTUS S/S. Memorial Descritivo do Projeto Executivo de Arquitetura Fiocruz Unidade Ceará. Fortaleza, 2012.

ARGAN, G. C. Urbanismo, espaço e ambiente. São Paulo: Martins Fontes, 2005.

AHERN, Jack F., "From fail-safe to safe-to-fail: sustainability and resilience in the new urban world" (2011). Landscape Architecture \& Regional Planning Graduate Research and Creative Activity. Paper 8. Link: Acessado em 16/05/2015. <http://scholarworks. umass.edu/larp_grad_research/8>

Benedict, Mark A., e McMahon, Edward T..Green Infrastructure - Linking Landscapes and Communities. Washington: Island Press, 2006.

BONZI, Ramón Stock. Andar sobre Água Preta: a aplicação da infraestrutura verde em áreas densamente urbanizadas. São Paulo: Universidade de São Paulo, 2015. 59 p. Dissertação (Mestrado em Arquitetura e Urbanismo) - Programa de Pós-Graduação em Arquitetura e Urbanismo, Universidade de São Paulo, São Paulo, 2015.

BRASIL. Lei n 6.938 de 31 de agosto de 1981. Política Nacional do Meio Ambiente.

BRASIL. LEI n 12.651, de 25 de maio de 2012. Código Florestal Brasileiro

BRITO, Ana Emilia. et al. Vegetação Costeira do Nordeste Semi-árido: Guia Ilustrado. Fortaleza: Edições UFC, 2006.

CANHOLI, Aluísio Pardo. Drenagem urbana e controle de enchentes. São Paulo: Oficina de Textos, 2005. 
Center for Watershed Protection. Manual 03: Urban Stormwater Retrofit Practices. 2007.

DRAMSTAD, W; OLSON, J; FORMAN, R;. Landscape Ecology Principles in Landscape Architecture and Land-Use Planning. Washington: Harvard University Graduate School of Design, 1996.

FORTALEZA. Decreto Municipal no 13.292, de 14 de janeiro de 2014. Regulamentação do Parque Rachel de Queiroz.Fundação Vanzolini. Escritório e Edifícios Escolares. Referencial Técnico de Certificação “Edifícios do setor de serviços - Processo AQUA. São Paulo, 2007.

GORSKI, Maria Cecília Barbieri. Rios e cidades: ruptura e reconciliação. São Paulo: Editora Senac São Paulo, 2010.

HABER, W. "Using Landscape Ecology in Planning and Management". In: Zonneveld, I.S.(Editor), Changing Landscapes: an ecological Perspective. New York: Springer verlag.1990, p67-100.

HERLING, Tereza. A Floresta em São Paulo, a Cidade na Cantareira: Fronteiras em Transformação. Tese (Doutorado), Faculdade de Arquitetura e Urbanismo da Universidade de São Paulo, 2002.

HERZOG, Cecilia P. Guaratiba Verde: subsídios para o projeto de Infraestrutura Verde em área de expansão urbana na cidade do Rio de Janeiro. Dissertação de Mestrado, Universidade Federal do Rio de Janeiro, Faculdade de Arquitetura e Urbanismo, Programa de Pós-Graduação em Urbanismo/PROURB, Rio de Janeiro, 2009.

LIMA, Catharina. O conflito de Gilgamesh. In: Paisagem e ambiente: ensaios. n. 18. São Paulo: FAUUSP, 2004. p. 07-57.

LORENZI, Harri; MOREIRA, Hermes. Plantas ornamentais no Brasil: arbustivas, herbáceas e trepadeiras. Nova Odessa, Instituto Plantarum, 2008.

MACEDO, SILVIOSOARES, SAKATA, FRANCINE GRAMACHO. Parque urbano brasileiro. 2003. EDUSP. São Paulo.

MAIA, Gerda Nickel. Caatinga: árvores e arbustos e suas utilidades. São Paulo: D\&Z Computação Gráfica e Editora, 2004.

MCHARG, I. Design with Nature. New York: The Natural History Press, 1971.

METZGER, Jean Paul. O que é ecologia de paisagens? . Biota Neotropica, 2001. 
MOURA, Newton Célio Becker de. Biorretenção: tecnologia ambiental urbana para manejo das águas de chuva. São Paulo, 2013. 177p. Tese (Doutorado - Área de Concentração: Paisagem e Ambiente) - Programa de Pós-Graduação em Arquitetura e Urbanismo, Universidade de São Paulo, 2013.

MUMFORD, L. A cidade na história: suas origens, transformações e perspectivas (4 ed.). (N. R. Silva, Trad.) São Paulo: Martins Fontes, 1998.

NOVOTNY, Vladimir. Water Quality: Diffuse Pollution and Watershed Management. . New Jersey: Wiley \& Sons, 2003.

PELLEGRINO, Paulo Renato M. “Fragmentos de Paisagem”, In: Paisagem e Ambiente: ensaios. n 9, 1996, p 47-82.

Pode-se Planejar a Paisagem? Paisagem \& Ambiente: ensaios n.13, 2000.

PELLEGRINO, P et al, A Paisagem da Borda: uma estratégia para a condução das águas, da biodiversidade e das pessoas. In COSTA, Lucia M. S. A. (org.) RIOS E PAISAGEM URBANA EM CIDADES BRASILEIRAS. Rio de Janeiro: Viana \& Mosley Editora/Editora PROURB, 2006. pg. 57-76. ISBN: 85-88721-38-4.

PELLEGRINO, Paulo R. M. \& CORMIER, Nathaniel S. Infraestrutura verde: uma estratégia paisagística para a água urbana. Paisagem \& Ambiente: ensaios. n. 25, 2008.

QUEIROGA, Eugenio Fernandes. Dimensões públicas do espaço contemporâneo: resistências e transformações de territórios, paisagens e lugares urbanos brasileiros. São Paulo, 2012. 284p. Tese (Livre Docência - Área de Concentração: Paisagem e Ambiente) - FAUUSP

RIGHETto, A. M. Manejo de Águas Pluviais Urbanas. Rio de Janeiro: ABES, 2009.

SANTOS, Milton. A Natureza do Espaço. Técnica e Tempo. Razão e Emoção. São Paulo: Universidade de São Paulo, 2006.

SHUTES, R. B. E. Artificial wetlands and water quality improvement. Environment International. 2001, V. 26, p. 441-447.

SPRIN, Anne Whiston. The Granite Garden. Urban Nature and Human Design. Basic Books, Harper Collins Publishers, 1984.

WATSON, Donald \& ADAMS, Michele. Design for Flooding. Architecture, Landscape and Urban Design for resilience and Management, Vol. 46: 5. P. 755-770. 


\section{Internet}

BIOMATRIX WATER. River Restoration. 2012.

Disponível em: <http://www.biomatrixwater.com/river-restoration/>. Acesso em: 28 de maio de 2014.

BMP, 2007. User's Guide International Stormwater Best Management Practices Database. Disponível em: <http://www.bmpdatabase.org/Docs/2007\%20BMP\%20Database\%20 User's\% 20Guide\%202\%200.pdf>. Acesso em: 15 de janeiro 2015.

Center of watershed protection. Disponivel em: <http://www.cwp.org/>. Acesso em: 13 de fevereiro de 2016.

Climage-KIC. Disponível em: <http://www.climate-kic-centre-hessen.org/blue-greendream.html>. Acesso em 12 de janeiro de 2016.

EPA - UNITED STATES ENVIRONMENTAL PROTECTION AGENCY - Constructed Treatment Wetlands. Office of Water, ago. 2004. Disponivel em: <http://www.epa.gov/owow/ wetlands/pdf/ConstructedW.pdf>. Acesso em: 29 de maio de 2014.

Jardim de Chuva em Portland. Disponivel em: <https://hpigreen.files.wordpress. com/2010/02/12th_ave_green_street.jpg>. Acesso em 18 de maio de 2015.

MAKSIMOVIC, Cedo et al. Blue-Green innovations in spatial planning. 2014. Disponível em: < http://resilient-cities.iclei.org/fileadmin/sites/resilient-cities/files/Resilient_Cities_2014/PPTs/E/E2_Maksimovic.pdf>. Acesso em 12 de janeiro de 2016.

RevistaDomus. Disponívelem: <http://www.domusweb.it/en/architecture/2015/02/11/ concrete_wave.html>. Acesso em: 05 de fevereiro de 2016.

REVISTA LABVERDE. 9. ed. São Paulo: FAUUSP, 2014. Disponível em: < http://www.fau. usp.br/depprojeto/revistalabverde/edicoes/ed09.pdf>. Acesso em: 29 de junho de 2016.

Rosa da Caatinga. Disponível em: <http://rosadacaatinga.blogspot.com.br/>. Acesso em: 10 de fevereiro de 2016.

Seattle SEA Street. Disponível em: <http://issuu.com/allyhangartner/docs/hangartner_ stormwaterthesisbook_pag>. Acesso em 18/05/2015. Acesso em: 05 de fevereiro de 2016. 
The Conservation Fund. 2004. Disponivel em: <http://www.conservationfund.org/images/programs/files/Floridas_Ecological_Network.pdf>. Acesso em: 13 de janeiro de 2016.

Urbanidades. Banco de imagens de urbanismo e planejamento urbano. Disponível em: <http://urbanidades.arq.br/bancodeimagens/displayimage.php?pos=-12> Acesso em: 14 de fevereiro de 2016.

Userful Tropical Plants. Disponível em: <http://tropical.theferns.info/>. Acesso em: 02 de abril de 2016. 



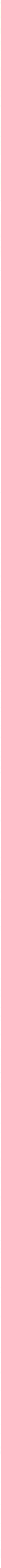

